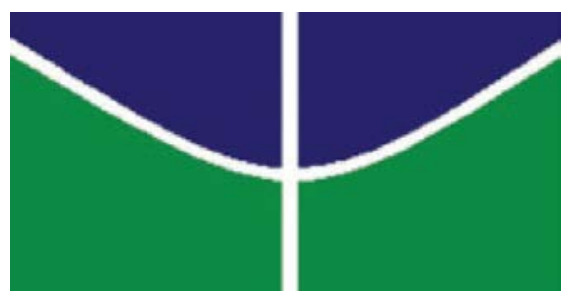

UNIVERSIDADE DE BRASÍLIA - UnB

INSTITUTO DE GEOCIÊNCIAS - IG

CURSO DE PÓS-GRADUAÇÃO EM GEOLOGIA

\title{
CARACTERIZAÇÃO PETROLÓGICA E METALOGENÉTICA DO DEPÓSITO DE Au DE MARMATO, MANIZALES, COLÔMBIA.
}

DISSERTAÇÃO DE MESTRADO Nº 369

Leonardo Santacruz Reyes

Brasília, DF, Agosto de 2016 


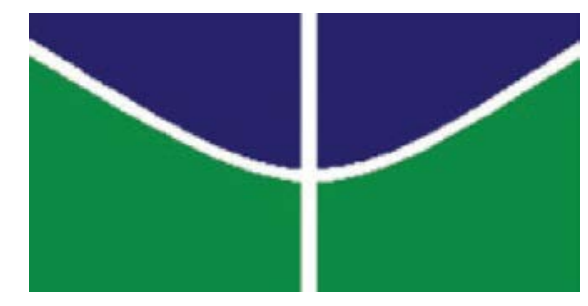

UNIVERSIDADE DE BRASÍLIA - UnB

INSTITUTO DE GEOCIÊNCIAS - IG

CURSO DE PÓS-GRADUAÇÃO EM GEOLOGIA

\section{CARACTERIZAÇÃO PETROLÓGICA E METALOGENÉTICA DO DEPÓSITO DE Au DE MARMATO, MANIZALES, COLÔMBIA.}

Leonardo Santacruz Reyes

Orientador:

Prof. Dr. Massimo Matteini (UnB)

Co-orientador:

Prof. Dr. Nilson Francisquini Botelho

Banca Examinadora:

Prof. Dr. Massimo Matteini (UnB)

Prof. Dr. Claudinei Gouveia de Oliveira (UnB)

Prof. Dr. José Carlos Frantz (UFRGS)

Brasília, DF, Agosto de 2016 


\section{RESUMO}

O depósito de ouro de Marmato se encontra localizado em uma das principais províncias minerais na Colômbia, o cinturão do Cauca Médio, associado a um arco vulcânico, com idade que varia do final do Oligoceno até o final de Mioceno. A suíte Marmato e Aguas Claras (MACS) hospeda mineralização de ouro epitermal na parte superior e do tipo vênulas na parte profunda do grupo Marmato e uma mineralização de ouro do tipo pórfiro no grupo Aguas Claras.

As idades da MACS se encontram entre 6,58 \pm 0,07 Ma e 5,74 \pm 0,14 Ma (U-Pb LA-ICP-MS, em zircão). Adularia hidrotermal relacionada com as zonas epitermal e do tipo vênulas, em profundidade, mostra idades 40Ar / 39Ar de 6,05 \pm 0,02 Ma e 5,96 \pm 0,02 Ma, as quais estão incluídas entre as intrusões pré e pós-mineralização do grupo Marmato.

A MACS é composta principalmente por andesitos e dacitos, cálcio-alcalinos a cálcio-alcalinos de alta $\mathrm{K}$, do tipo oxidado, pertencentes à série magnetita com alta porcentagem de Mn-ilmenita e baixa de magnetita, caracterizadas por uma assinatura "semelhante aos adakitos" com relativamente alta relação $\mathrm{Sr} / \mathrm{Y}(>55)$, baixa La/Yb $(<20)$, $\mathrm{Mg \#}<0.5$, e $\mathrm{Dy}_{\mathrm{N}} / \mathrm{Yb}_{\mathrm{N}}<1.5$. A geoquímica e as composições isotópicas de Sr-Nd sugerem um magma gerado pela fusão parcial da cunha do manto seguido de uma mínima contaminação crustal e continuado por uma cristalização fracionada em condições de alta $\mathrm{fO}_{2}$ e hidratação. Semelhanças de composição entre a MACS e intrusões espacialmente associadas com depósitos de ouro na Colômbia refletem processos semelhantes à escala regional para a geração de intrusões produtivas, até o final do Mioceno, logo depois de um período prolongado de magmatismo de arco, que começou no final do Oligoceno e ainda se encontra ativo.

As rochas magmáticas enriquecidas com Mn-ilmenita não apenas sugerem alta $\mathrm{fO}_{2}$ no magma, mas também, em conjunto com pirrotita hidrotermal, caracterizam a mineralização de $\mathrm{Au}$ de Marmato do tipo epitermal, para o tipo de vênulas em profundidade, gerando valores de média-baixa susceptibilidade e intensidades da magnetização remanescente natural (NRM). Isto ressalta a importância deste tipo de depósito como alvos interessantes para exploração no arco vulcânico Mioceno, na Colômbia, além daqueles com típica magnetita magmática-hidrotermal associada (disseminada/vênulas).

Palavras chave: Depósito de ouro de Marmato, epitermal, pórfiro, “similar aos adakitos”, Mn-ilmenita. 


\section{ABSTRACT}

The Marmato gold deposit is located in one of the premier mineral provinces of Colombia, the Middle Cauca belt, associated with a late Oligocene to late Miocene volcanic arc. Gold mineralizations hosted in the Marmato and Aguas Claras suite (MACS) are epithermal in the upper zone and veinlet-type in the lower zone of the Marmato group, and porphyry gold in the Aguas Claras group.

The MACS was dated between $6.58 \pm 0.07 \mathrm{Ma}$ and $5.74 \pm 0.14 \mathrm{Ma}$ (U-Pb LA-ICP-MS in zircon). Epithermal to veinlet at depth related hydrothermal adularia yielded a weighted plateau ${ }^{40} \mathrm{Ar} /{ }^{39} \mathrm{Ar}$ age of $(6.05 \pm 0.02)$ Ma to $(5.96 \pm 0.02) \mathrm{Ma}$, for two samples, which are between the age of pre and pos-mineralization Marmato porphyry intrusions.

The MACS is mainly composed by andesite to dacite rocks, calc-alkaline to high $\mathrm{K}$ calcalkaline, oxidized type - magnetite series with high Mn-ilmenite contents and low magnetite, characterized by an "adakite-like” signature with relatively high $\mathrm{Sr} / \mathrm{Y}(>55)$, low $\mathrm{La} / \mathrm{Yb}(<20)$, Mg\# <0.5, and $\left(\mathrm{Dy}_{\mathrm{N}} / \mathrm{Yb}_{\mathrm{N}}\right)<1.5$. Geochemistry and Sr-Nd isotopic compositions suggest a magma generated by partial melting of the mantle wedge followed by minimal crustal contamination and crystal fractionation at high $\mathrm{fO}_{2}$ - hydrous conditions. Compositional similarities between the MACS and spatially associated intrusions with gold deposits in Colombia mostly reflect similar regional-scale process for the generation of productive intrusions through the late Miocene after a prolonged period of arc magmatism that began in the late Oligocene (and is still active).

Magmatic Mn-ilmenite bearing rocks not just suggest high $\mathrm{fO}_{2}$ in the magma, but also along with hydrothermal pyrrhotite characterized the Marmato epithermal to veinlet at depth Au mineralization and generate medium low susceptibility values and natural remanent magnetization (NRM) intensities. This highlight the importance of this type of deposit as interesting targets for exploration in the late Miocene volcanic arc in Colombia, in addition to those with typical associated magmatic-hydrothermal bearing magnetite (disseminate/veinlets).

Key words: Marmato gold deposit, epithermal, porphyry, “Adakite like”, Mn-ilmenite. 



\title{
SUMÁRIO
}

\author{
CAPÍTULO 1. INTRODUÇÃO \\ 1.1 APRESENTAÇÃO \\ 1.2 LOCALIZAÇÃO E ACESSO \\ 1.3 JUSTIFICATIVA E OBJETIVOS DO TRABALHO \\ CAPÍTULO 2: CONTEXTO GEOLÓGICO REGIONAL \\ 2.1 MARCO GEOLÓGICO REGIONAL \\ 2.2 MARCO GEOLOGICO LOCAL \\ CAPÍTULO 3: MÉTODOS ANALÍTICOS \\ 3.1 PETROGRAFIA \\ 3.2 MICROANÁLISES DE SONDA ELETRÔNICA - (EPMA) \\ 3.3 LITOGEOQUÍMICA \\ 3.4 GEOCRONOLOGIA \\ 3.5 ISÓTOPOS SR-ND
}

CAPITULO 4: "GEOCHRONOLOGY, GEOCHEMISTRY AND OXIDES CARACTERIZATION OF THE MARMATO GOLD DEPOSIT, COLOMBIA: IMPLICATIONS FOR MINERALIZATION AND REGIONAL EXPLORATION”.

\section{1 $\underline{\text { Abstract }}$}

4.2 Introduction

4.3 Regional Geologic Setting

4.4 Local Geologic Setting

4.5 Sampling and Analytical Methods

4.5.1 Petrography

4.5.2 Electron Probe Microanalyzer- EPMA

4.5.3 Lithogeochemistry

4.5.4 Geochronology

4.5.5 Sr-Nd isotopes

4.6 Results 
4.6.1 Petrography of porphyry intrusions and relative chronology

4.6.2 Oxide Petrography

4.6.3 Lithogeochemistry

4.6.4 Oxides chemistry

4.6.5 U-Pb age determinations

4.6.6 Age of mineralization by ${ }^{40} \mathrm{Ar} /{ }^{39} \mathrm{Ar}$ incremental heating

$\underline{4.6 .7}$ Sr-Nd Isotopes

4.7 Discussion

4.7.1 Ages of the magmatism and Marmato gold mineralization

4.7.2 “Adakite like" rocks

4.7.3 Tectonic setting and characteristics of the magma

4.7.4 Source of the magma and comparison with related igneous rocks

4.7.5 Implications for mineralization and regional exploration

$\underline{4.8}$ Conclusions

4.9 Acknowledgments

CAPITULO 5: CONCLUSÕES

REFERÊNCIAS BIBLIOGRÁFICAS

ANEXOS 


\section{ÍNDICE DE FIGURAS}

Figura 1. Zonas vulcânicas da América do Sul e Bloco Norte Andino.

Figura 2. Principais reinos tectônicos da Colômbia e rochas magmáticas do Neogeno ao longo dos Andes colombianos

Figura 3. Mapa geológico local do depósito de ouro Marmato.

Figura 4. Perfil esquemático que mostra a ocorrência de intrusões P1 a P5.

Figura 5. Perfil esquemático que mostra a ocorrência de intrusões AP1 a AP5

Figura 6. Perfil do depósito de Marmato

Figura 7. Rochas de veios no Marmato em amostras de mão (zona superior).

Figura 8. Rochas com vênulas no Marmato em amostras de mão (zona inferior)

Figure 1 Volcanic zones of South America and Northern Andean Block

Figure 2 Principal tectonic realms of Colombia and Neogene magmatic rocks over the Colombian Andes

Figure 3 Local geological map of the Marmato gold deposit

Figure 4. Schematic profile showing the occurrence of intrusions P1 to P5.

Figure 5. Schematic profile showing the occurrence of intrusions AP1 to AP5.

Figure 6. Marmato deposit section showing the two principal zones.

Figure 7. Marmato veins rocks types in hand specimen (Upper zone)

Figure 8. Marmato veinlets rocks types in hand specimen (Lower zone)..

Figure 9. Marmato (P1 to P5) and Aguas Claras (AP1 to Ap5) rocks in hand sample.

Figure 10 Marmato (P1 to P5) and Aguas Claras (AP1 to Ap5) rocks in thin sections

Figure 11 EPMA images from MACS

Figure 12 Primary hydrothermal mineral assemblages in the Marmato and Aguas Claras deposits.

Figure 13 Total alkali-silica classification diagram from LeBas et al., (1986) for MACS rocks.

Figure 14 Harker diagrams for Marmato and Aguas Claras groups.

Figure $15 \mathrm{C} 1$ normalized normalized REE diagram for Marmato group

Figure 16 C1 normalized REE diagram for Aguas Claras group.

Figure $17 \mathrm{Sr} / \mathrm{Y}$ vs $\mathrm{Y}, \mathrm{La} / \mathrm{Yb}$ vs $\mathrm{Yb}$ and $\mathrm{Eu}_{\mathrm{N}} / \mathrm{Eu}^{*}$ vs $(\mathrm{Dy} / \mathrm{Yb})_{\mathrm{N}}$

Figure 18 Primordial mantle normalized trace element patterns for the Marmato group. 
Figure 19 Primordial mantle normalized trace element patterns for Aguas Claras group.. Figure $20 \mathrm{U}-\mathrm{Pb}$ LA-ICP-MS dating in zircons

Figure $21 .{ }^{40} \mathrm{Ar} /{ }^{39} \mathrm{Ar}$ ages spectra for two hydrothermal adularia samples of the Marmato gold deposit

Figure 22 Relationship between U-Pb dating for MACS and Ar-Ar Marmato mineralization age

Figure $23{ }^{87} \mathrm{Sr} /{ }^{86} \mathrm{Sr}$ vs ${ }^{143} \mathrm{Nd} /{ }^{144} \mathrm{Nd}$.

Figure $24 \Delta \log \mathrm{fO}_{2}-\mathrm{T}$ diagram

Figure 25 Aeromagnetic survey. Reduced to the Pole image 


\section{ÍNDICE DE TABELAS}

Table 1 Textural and mineralogical characteristics of MACS intrusions. Table 2. Parameters and characteristic values for Adakites rocks compared with MACS.. Table 3 Representative EPMA oxides analysis in the MACS 


\section{ÍNDICE DE ANEXOS}

Annex 1 EPMA magnetites analysis in the MACS

Annex 2 EPMA ilmenites analysis in the Marmato porphyry group

Annex 3. EPMA ilmenites analysis in the Aguas Claras porphyry group

Annex 4. U-Pb geochronological data obtained from Marmato group intrusions

Annex 5. U-Pb geochronological data obtained from Aguas Claras group

Annex 6. Ar-Ar geochronological plateau age data obtained from hydrothermal adularia in the Marmato gold deposit (Upper zone).

Annex 7. Ar-Ar geochronological plateau age data obtained from hydrothermal adularia in the Marmato gold deposit (Lower zone).

Annex 8. Ar-Ar geochronological isochron age data obtained from hydrothermal adularia in the Marmato gold deposit (Upper zone).

Annex 9. Ar-Ar geochronological isochron age data obtained from hydrothermal adularia in the Marmato gold deposit (Lower zone).

Annex 10. Sr/Nd isotopic compositions of the MACS 


\section{CAPÍTULO 1. INTRODUÇÃO}

\subsection{APRESENTAÇÃO}

O depósito de ouro Marmato está localizado no flanco oriental da Cordilheira Ocidental da Colômbia (45 km ao norte da cidade de Manizales, Distrito de Caldas). Trabalhos de exploração feitos pela Gran Colombia Gold Corp., mostram recursos estimados a céu aberto de 11.8 Moz Au e 80.3 Moz Ag em 409.7 Mt com valores de $0.9 \mathrm{~g} / \mathrm{t}$ Au e $6.1 \mathrm{~g} / \mathrm{t} \mathrm{Ag}$ nas categorias de medidos e indicados, além de $2.60 \mathrm{Moz}$ Au e 9.4 Moz Ag em 79.10 Mt com valores de $1.02 \mathrm{~g} / \mathrm{t}$ Au e $3.7 \mathrm{~g} / \mathrm{t}$ Ag na categoria de inferidos, com base num teor de corte de $0.3 \mathrm{~g} / \mathrm{t}$ Au e um preço do ouro de US \$1.400 por onça, para uma total de 496 Mt contendo 15.0 Moz Au e 90.0 Moz Ag (Parsons, 2012). A produção passada se estima entre 1.75 e $2.25 \mathrm{Moz}$ Au (Redwood, 2011).

O depósito de ouro Marmato consiste num sistema em veio epitermal estruturalmente controlado com uma associação mineral dominada por pirita, arsenopirita, marmatita, pirrotita, calcopirita e ouro electrum (zona superior) e um sistema do tipo vênulas, com uma associação mineral dominada por pirrotita, calcopirita, bismuto e ouro livre (zona inferior), associado com a suíte de Marmato e Aguas Claras (MACS) do final do Mioceno, localizado na parte sul do stock de Marmato.

O stock de Marmato é um corpo alongado N-S (18 km de comprimento e $3 \mathrm{~km}$ de largura) intrusivo durante o final do Mioceno até o início do Plioceno (Aspden et al, 1987;. Tassinari et al., 2008) que hospeda as mineralizações de ouro do tipo epitermal e pórfiro no Marmato e Aguas Claras as quais são semelhantes a outros depósitos de ouro do final do Mioceno localizados no vale do Cauca meio (Sillitoe et al, 1982;. Sillitoe e Hart, 1984; Rodriguez e Warden, 1993; Sillitoe, 2008; Leal-Mejía, 2011; Lesage et al., 2013). Alguns estudos anteriores da mineralização têm sido realizados no Marmato (Bedoya, 1998; Rossetti e Colombo, 1999; Tassinari et al, 2008; Santacruz, 2011), embora nenhum deles tenha realizado um programa completo de datação, nem considerado o papel da litogeoquímica e a química mineral dos óxidos na geração e caracterização do depósito.

O nosso objetivo é conhecer a idade do magmatismo e da mineralização no depósito de ouro Marmato e a evolução petrogenética da MACS para avaliar as implicações metalogenéticas desses parâmetros e contribuir para a exploração regional no arco magmático, no final do Mioceno, na Colômbia. Nós apresentamos um conjunto de dados de datações (U-Pb LA-ICP-MS) e (40Ar-39Ar), composição geoquímica e isotópica das intrusões na suíte de Marmato e Aguas Claras (MACS), e dados de sonda eletrônica para 
óxidos. Finalmente, nos fizemos uma comparação com os depósitos de ouro relacionados de La Colosa e Buritica.

\subsection{LOCALIZAÇÃO E ACESSO}

A área de estudo encontra-se localizada na Colômbia, no departamento de Caldas, em jurisdição do corregimento de Marmato, $30 \mathrm{~km}$ ao norte da cidade de Manizales (Figure 2). Essa região encontrasse no limite entre as Cordilleras Central e Ocidental. Trata-se de uma zona povoada, de fácil acesso e com estradas em boa condição. O acesso desde a cidade de Bogotá pode ser conseguido de carro, tomando a rodovia principal Bogotá-Medellín, posteriormente a rodovia Medellín-Manizales e finalmente a rodovia para o povoado de Marmato. Alternativamente pode se tomar um avião desde a Cidade de Bogotá, com destino a cidade de Manizales ou Medellin.

\subsection{JUSTIFICATIVA E OBJETIVOS DO TRABALHO}

O presente trabalho foi desenvolvido com o interesse de entender os processos regionais e locais na formação de magmas produtivos relacionados com depósitos de ouro do tipo epitermal-pórfiro, tomando como objetivo de estudo, o deposito de ouro epitermalpórfiro de Marmato e o comparando com outros depósitos, relacionados no arco vulcânico do Mioceno tardio na Colômbia.

Tradicionalmente os estudos realizados ao redor da mineralização de ouro de Marmato são focados nas descrições petrográficas e nas características dos fluidos geradores da mineralização (Bedoya, 1998; Rossetti e Colombo, 1999, Santacruz, 2011), enquanto poucos trabalhos têm ido além e considerado as suas origens e contextos geodinâmicos de geração (Tassinari et al, 2008). Importantes avanços no entendimento dos arcos vulcânicos na Colômbia e sua importante relação com os depósitos minerais na sua evolução começaram a ser desenvolvidos no século XX (Aspden et al, 1987; Sillitoe et al, 1982;. Sillitoe e Hart, 1984; Rodriguez e Warden, 1993). Sendo este um grande avanço, visto que conseguiu articular essa parte do magmatismo, junto com os principais depósitos de ouro especialmente no arco vulcânico do Mioceno tardio. Posteriormente, importantes trabalhos têm realçado e aprofundado o entendimento desta relação (Sillitoe, 2008; LealMejía, 2011; Lesage et al, 2013).

Porém, atualmente é difícil enxergar a relação do magmatismo-mineralização na história geológica da Colômbia e este trabalho é uma das primeiras tentativas de estabelecer a origem das rochas geradoras, e suas implicações na geração e exploração de depósitos de ouro no arco vulcânico da Colômbia. Esse novo conhecimento vai contribuir para o refinamento dos atuais modelos de geração e evolução de magmas produtivos e improdutivos para depósitos minerais. Por outro lado, o deposito de ouro de Marmato tem 
sido tradicionalmente reconhecido como um dos maiores e mais representativos depósitos no cinturão do Cauca Medio, com os recursos de open pit estimados em 15 (Moz) Au e 90 (Moz) Ag com teores de 0.94 g/t Au e 5.65 g/t Ag contidas em 496 milhões de toneladas, com uma teor de corte de $0.3 \mathrm{~g} / \mathrm{t}$ Au. Pelo qual o conhecimento da petrologia do deposito e sua relação com a mineralização constitui o primeiro passo para o seu entendimento e para encaminhar futuros estudos de pesquisa mineral e petrologia que permitam identificar e desenvolver metodologias de exploração para projetos de mineração, os quais permitam um avanço econômico para a região e para o país.

Entre os objetivos da pesquisa foi contemplado: 1) Limitar o tempo do magmatismo no deposito de Marmato, baseado na determinação das idades dos corpos intrusivos por meio de análises geocronológicas; 2) Determinar as características geoquímicas e de formação dos corpos intrusivos, baseado em análises químicas de elementos maiores, menores e traço e de geoquímica isotópica; e 3) Determinar as composições químicas dos principais óxidos dos corpos intrusivos, através de microanálises de sonda eletrônica; e 4) Formular modelos conceituais da origem, evolução geológica e relação com a mineralização para o deposito de Marmato e comparar com outros depósitos relacionados no arco vulcânico do Mioceno tardio.

Os resultados do trabalho são apresentados na forma de artigo, que constitui o capítulo 4 e será submetido na Economic Geology. Atendendo as normas do programa de Pós-Graduação em Geologia, para dissertações na forma de artigo em inglês, são apresentados, em português, os capítulos de Introdução, Materiais e Métodos e Geologia Regional e um capítulo final com as principais conclusões do trabalho. 


\section{CAPÍTULO 2: CONTEXTO GEOLÓGICO REGIONAL}

\subsection{MARCO GEOLÓGICO REGIONAL}

Os Andes colombianos estão incluídos no bloco norte dos Andes, o qual inclui a zona vulcânica norte (ZVN) (Gansser, 1973; Shagam, 1975) (Figura 1 A-B), e compreendem três cinturões de montanhas com orientação N-NNE, as Cordilheras, Ocidental, Central e Oriental, as quais se encontram separadas por duas depressões principais, o Cauca-Patia e o Magdalena, desde o oeste para o leste, e representam adicionalmente limites de terrenos (Figura 1). Os Andes colombianos têm uma complexa história de vulcanismo, subducção, acressão e falhamento, representada pela justaposição de rochas metamórficas, ígneas e sedimentares de várias idades, a partir do pré-cambriano até o presente (Aspden et al, 1987; Restrepo e Toussaint, 1988; Taboada et al., 2000; Pindell e Kennan, 2009).
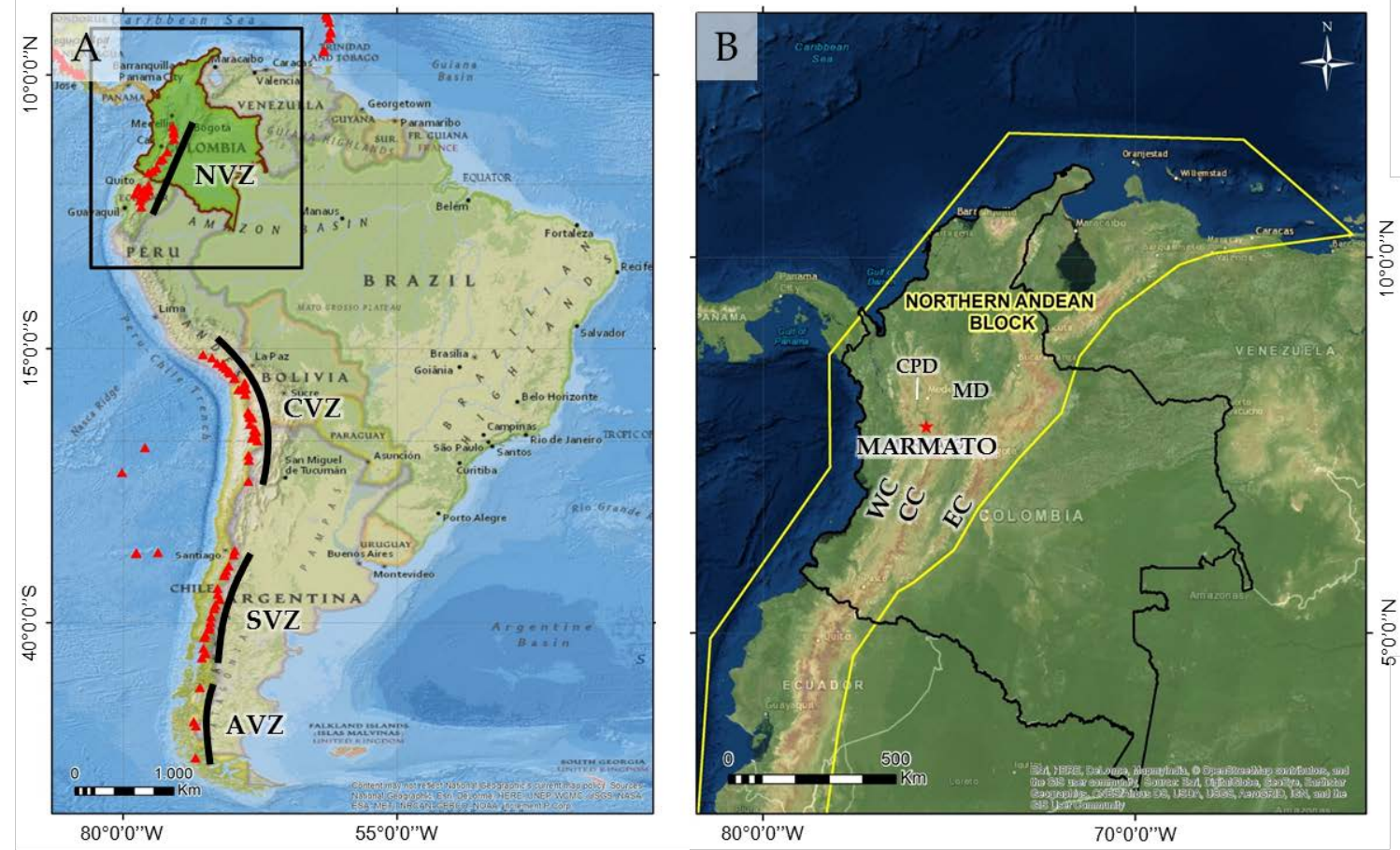

Figura 1. A. Zonas vulcânicas da América do Sul. NVZ: Zona vulcânica do Norte; CVZ: Zona Vulcânica Central; SVZ: Zona vulcânica do sul; AVZ: Zona vulcânica austral. B. Bloco norte andino o qual compreende os Andes colombianos. WC: Cordilheira Ocidental; CC: Cordilheira Central; CE: Cordilheira Oriental; CPD: Depressão do Cauca-Patia; MD: Depressão do Magdalena. 
Para explicar a complexa configuração geológica da Colômbia, (Cediel et al., 2011) propuseram nove principais reinos tectônicos que podem compreender, ao mesmo tempo diferentes terrenos: 1) O escudo de Guiana; 2) A sub-placa de Maracaib; 3) A sub-placa continental Central; 4) Os terrenos do Pacífico; 5) Os terrenos do Caribe; 6) O arco ChocoPanamá; 7) O terreno Guajira; 8) A placa do Caribe; e 9) A placa de Nazca (Figura 2 A).

Marmato encontra-se localizado no lado oriental da Cordilheira Ocidental, a qual é separada da Cordilheira Central a leste pelo rio Cauca e situa-se dentro do terreno Romeral, delimitado pela falha do Cauca (Oeste) e pela falha Romeral (Leste) e faz parte do reino dos terrenos do Pacífico (Figura 2 B). Neste trabalho é apresentado apenas um resumo da geologia da Cordilheira Ocidental em torno de Marmato. Descrições detalhadas da geologia colombiana incluem Campbell (1974), Shagam (1975), Etayo et al. (1983), e Cediel Cáceres (2000), Cediel et ai. (2003), Cáceres et ai. (2003), Cediel et al., (2011) e Gómez et al. (2015).
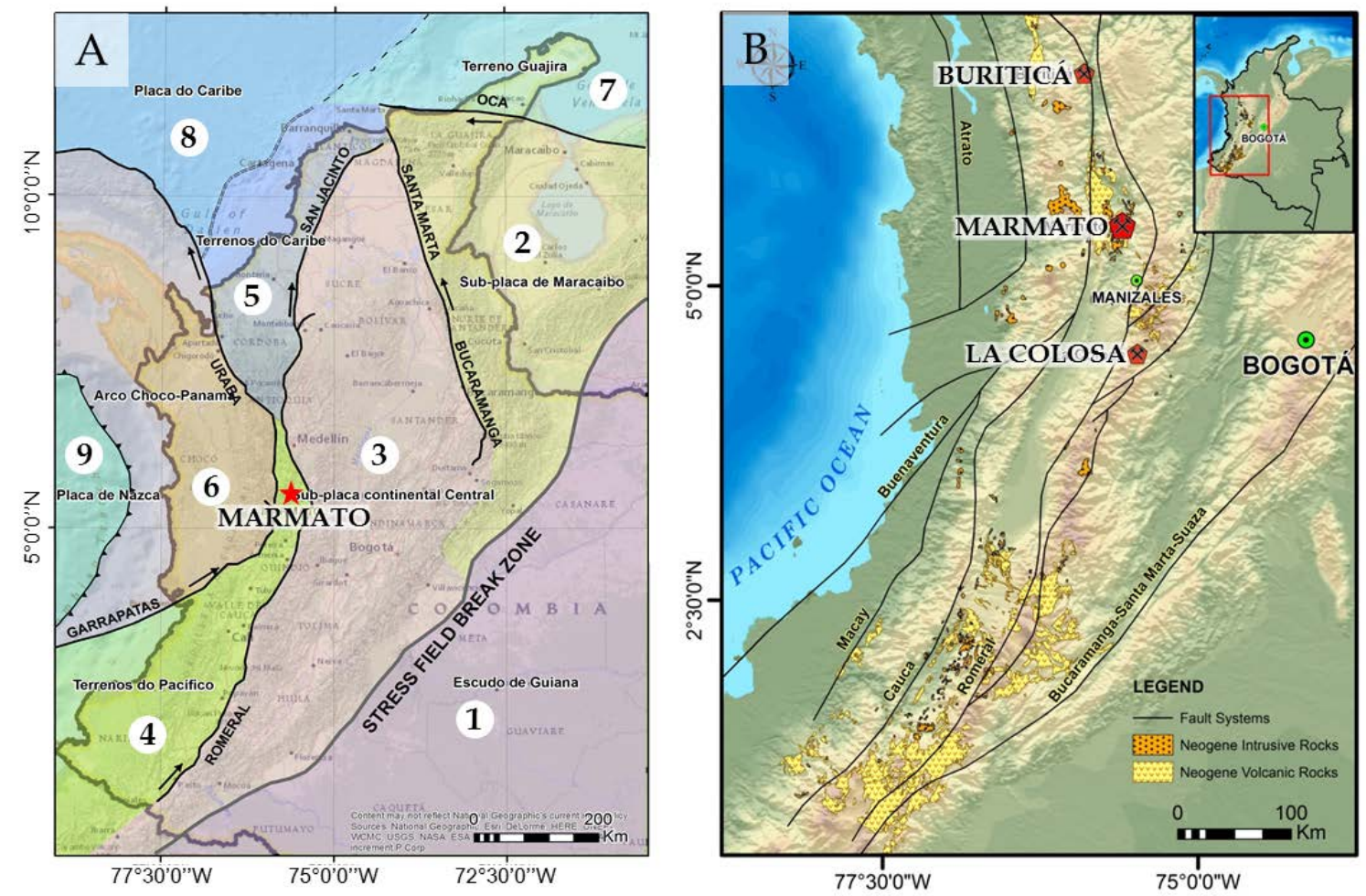

Figura 2. A. Principais domínios tectônicos da Colômbia (Modificado a partir de Cediel et al, 2011.): 1) Escudo da Guiana; 2) Sub-placa de Maracaibo; 3) Sub-placa continental central; 4) Terrenos do Pacífico; 5) Terrenos do Caribe; 6) Arco Choco-Panamá; 7) Terreno da Guajira; 8) Placa do Caribe; 9) Placa de Nazca B. Rochas magmáticas do Neogeno (Principalmente final do Oligoceno para final do Mioceno) ao longo dos Andes colombianos. Modificado a partir do mapa geológico da Colômbia (Colômbia Geological Survey, 2015). Os depósitos de Marmato, La Colosa e Buriticá se encontram localizados no cinturão de ouro no vale do Cauca médio. 
O terreno Romeral é um fragmento oceânico compreendendo complexos máficos e ultramáficos metamerizados, sequências de ofiolitos e sedimentos oceânicos com idades prováveis Jurássico-Cretáceo Inferior (Cediel e Cáceres, 2000; Cediel et al., 2003). Este foi acrescido na margem continental ao longo da falha Romeral, no Aptiano (125-110 Ma), e agora faz parte ao leste, do basamento da Cordillera Central, ficando do lado leste do rio Cauca. O movimento na falha de Romeral foi dextral (Cediel e Cáceres, 2000; Cediel et al., 2003), indicando que o terreno acrescido foi altamente oblíquo desde o sul-oeste. Estas rochas compreendem o encaixante do stock porfirico de Marmato e incluem metabasaltos, anfibolitos, serpentinitos, xisto grafitosos, biotita xistos, sericita xistos e clorita xistos, os quais constituem o complexo Arquia (Calle et al, 1984;.. Durán et al, 2005).

A zona de falha de Romeral é marcada por ofiolítos com metamorfismo dinâmico, incluindo o glaucofana xisto num melange tectônico, e interpretada como uma sutura entre terrenos que marcam uma antiga zona de subducção.

O terreno Romeral é delimitado no lado oeste pela falha do Cauca e encontra-se parcialmente coberto por sedimentos continentais de idade Oligoceno-Mioceno Inferior correspondentes à Formação Amagá, compreendendo conglomerados de cor cinza-verde, arenitos, folhelhos e camadas de carvão, que são recobertos por espessas sequencias de rochas vulcânicas e sedimentos da Formação Combia, de idade Mioceno Tardio, a qual é dividida em Membro Inferior, com fluxos de lava basáltica e andesitica, aglomerados e tufos, e um Membro Superior com conglomerados, arenitos e tufos (Durán et al., 2005). Mais para o oeste, terrenos adicionais de arcos oceânicos e insulares foram posteriormente acrescidos para a Cordilheira Ocidental nos períodos Paleógeno e Neogeno, culminando na colisão em curso do arco Panamá-Choco, desde o final do Mioceno. Isto reativou as falhas Cauca e Romeral, com movimentos reversos laterais esquerdos (Cediel e Cáceres, 2000; Cediel et al., 2003). O afinamento crustal e reativação das falhas Romeral e Cauca desencadeadas pela acressão do bloco Panamá-Choco sobre a Cordilheira Ocidental, entorno aos 12 Ma permitiu a ocorrência de intrusões no Mioceno Tardio ao longo do vale do Cauca Meio (Duque-Caro, 1990; ego e Sebrier, 1995; Tassinari et al, 2008).

O stock de Marmato faz parte do magmatismo Mioceno (Figura 2 B), caracterizado por intrusões subvulcânicas calco-alcalinas e rochas vulcânicas da Formação Combia. O magmatismo Mioceno corta as unidades do Terreno Romeral, as unidades plutônicas do Albiano e do início do Cenozóico, e as sequências siliciclásticas da Formação Amagá, depositada numa bacia pull-apart (Restrepo et al, 1981; Cáceres et al., 2003; Tassinari et al, 2008). O magmatismo Mioceno relacionado com ouro na Colômbia tem sido bem reconhecido nas Cordilheiras Ocidental e Central, associado com batólitos e stocks (Sillitoe et al, 1982;. Alvarez, 1983; Sillitoe e Hart, 1984; Aspden et al, 1987;. Toussaint e Restrepo , 1988; Rodriguez e Warden, 1993; López et al, 2006;. Sillitoe, 2008;. Lodder et al, 2010; 
Leal-Mejía, 2011;. Lesage et al, 2013) (Figura 2 B). Além disso, magmatism do Mioceno Tardio-Plioceno tem sido reconhecido no Maciço de Santander, na parte norte da Cordilheira Oriental (Mantilla et al., 2009), com uma mineralização de ouro relacionada.

\subsection{MARCO GEOLOGICO LOCAL}

O depósito de ouro de Marmato é hospedado pelo stock de Marmato, com rochas porfiríticas de composição andesito e dacito. O stock tem $18 \mathrm{~km}$ de comprimento e 3 a 6 km de largura e é alongado de norte a sul (Calle et al., 1984). Ele intrude a Formação Amaga e o Complexo Arquia, no lado leste do vale do Cauca, e faz parte da Formação Combia no lado oeste. O depósito de ouro Marmato se encontra hospedado por um conjunto de pórfiros, compreendidos num estoque com dimensões de cerca de $3.0 \mathrm{~km}$ N-S por 1.6-2.5 km de largura, perto do extremo sul do stock principal de Marmato. Cinco intrusões de pórfiros principais foram identificadas no depósito de ouro Marmato, denominadas P1 a P5, desde o mais antigo até o mais jovem (Grupo pórfiro Marmato) (Figura 3-Figura 4).

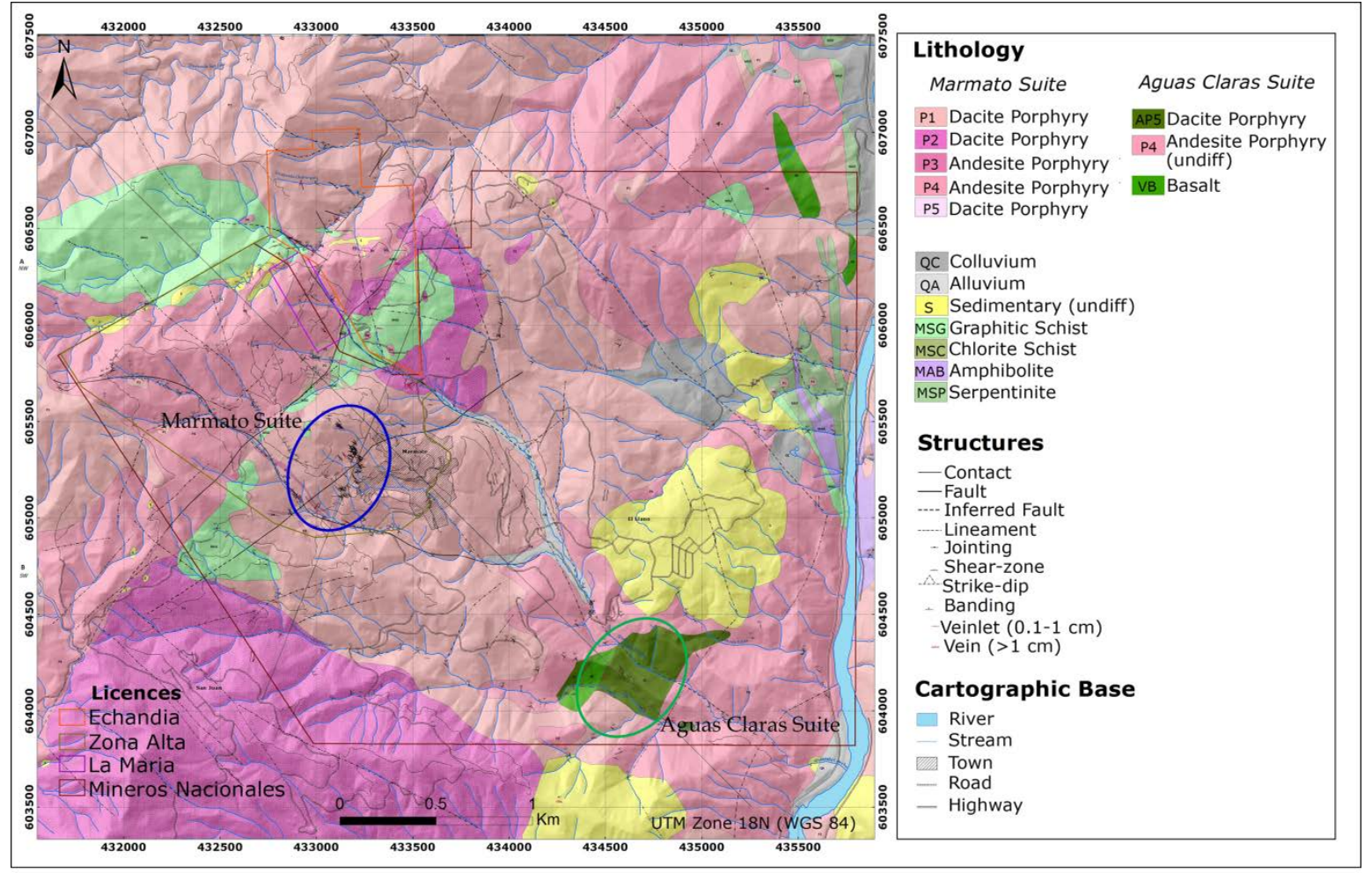

Figura 3. Mapa geológico local do depósito de ouro Marmato sobreposto num modelo de elevação digital (DEM). Gran Colombia Gold Corp. 
Idades de resfriamento das intrusões têm sido mostradas anteriormente desde 7,1 \pm 0,2 Ma (Rodrigues, 1987, citado em Rodrigues e Warden, 1993) até 6,3 \pm 0,7 Ma (Gonzalez, 1980, citado em: Sillitoe et al., 1982), ambos pelo o método K-Ar. Outro grupo pórfiro é diferenciado pela sua localização geográfica e se encontra composto de cinco intrusões porfiríticas, com nomes AP1 a AP5, desde o mais antigo até o mais novo (grupo pórfiro Aguas Claras) apresentando-se uns $3 \mathrm{~km}$ ao SW do grupo pórfiro Marmato (Figura 3 e Figura 5). Duas intrusões do grupo de Marmato P3 e P5 cortam o grupo Aguas Claras em forma de diques. Porém não se tem datações do grupo de pórfiro Aguas Claras.

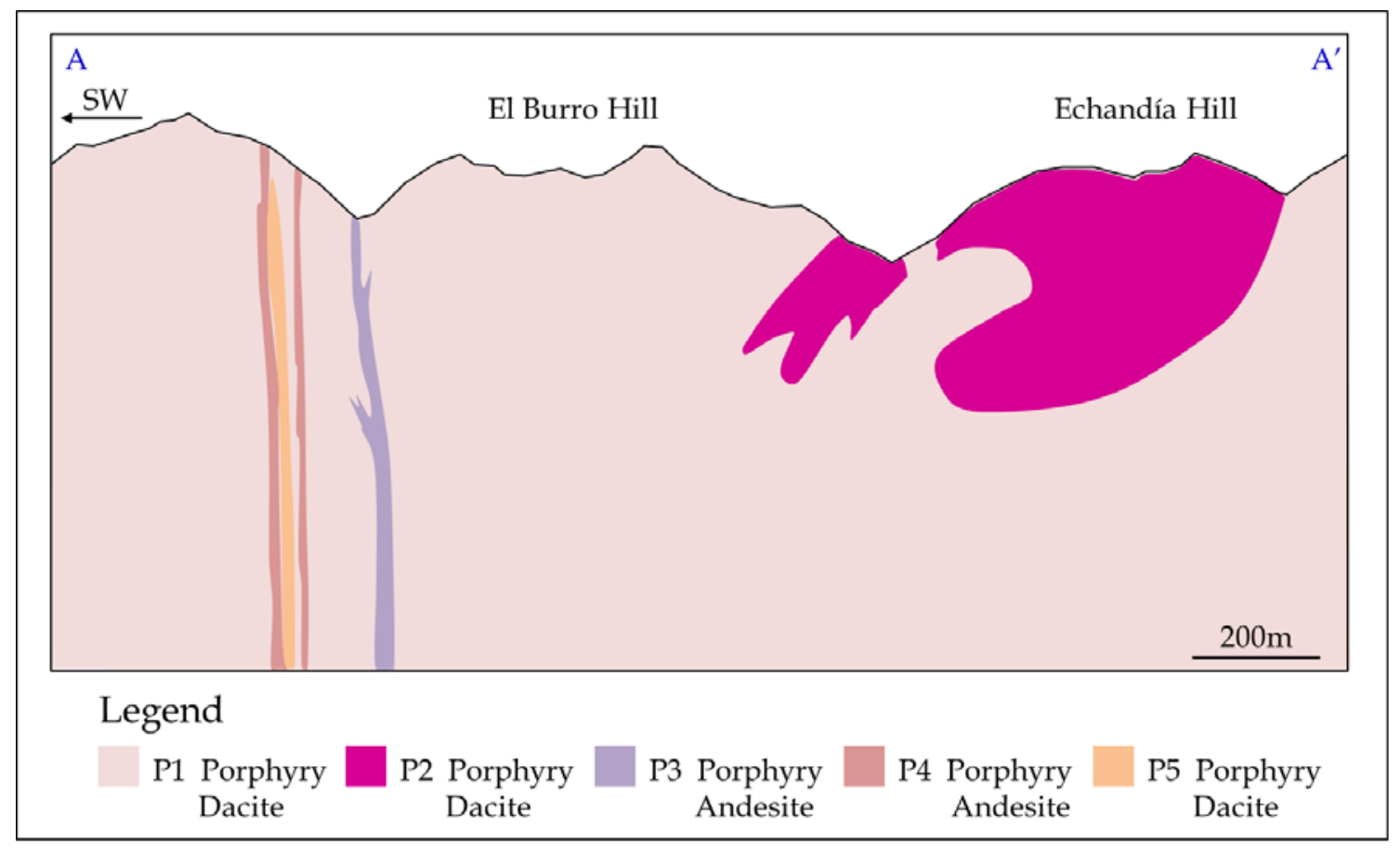

Figura 4. Perfil esquemático que mostra a ocorrência de intrusões P1 a P5 no depósito de ouro Marmato. O depósito de ouro Marmato se encontra principalmente embaixo da colina El Burro e ao SW da colina Echandía. 


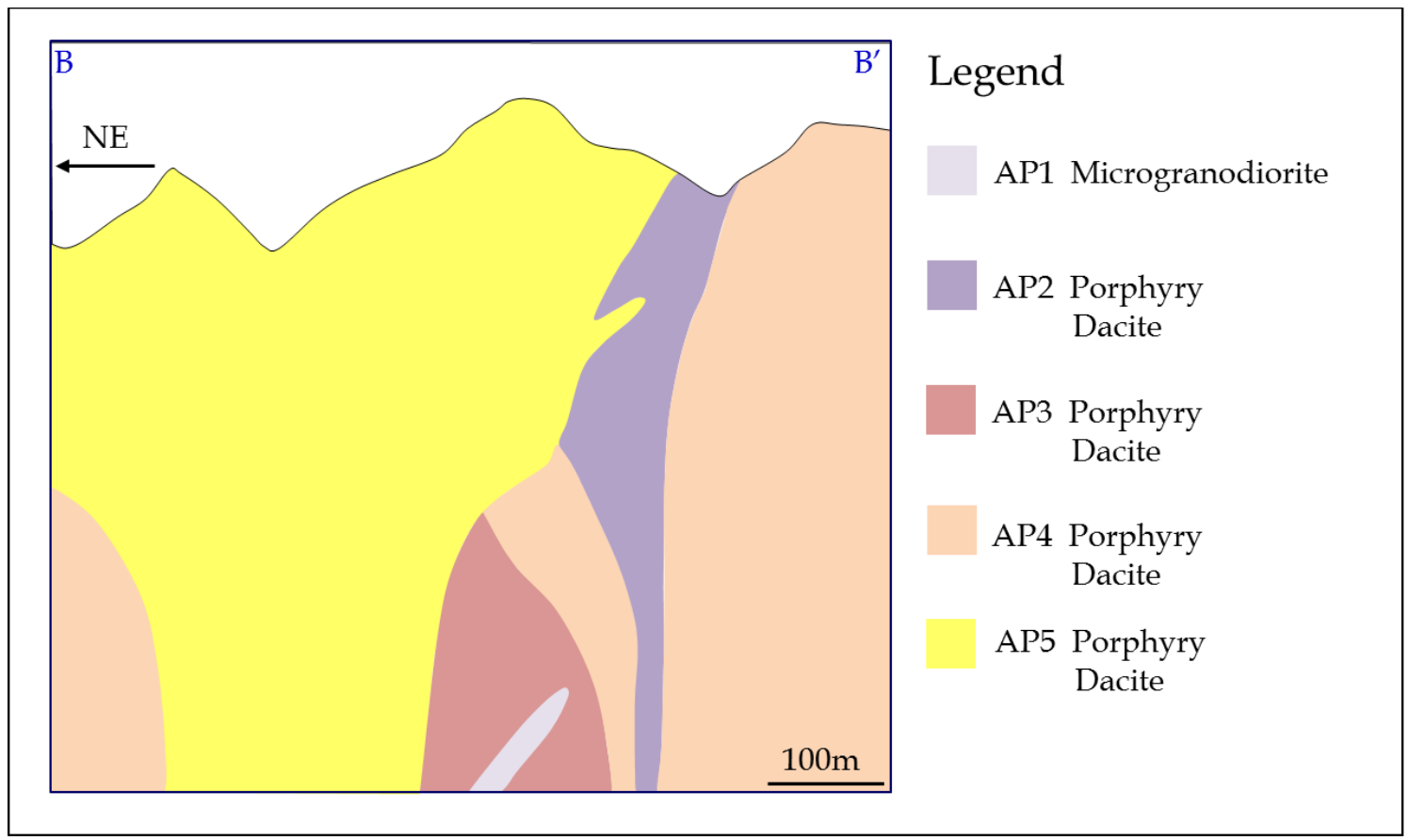

Figura 5. Perfil esquemático que mostra a ocorrência de intrusões AP1 a AP5 no depósito de Aguas Claras. O depósito de Aguas Claras se encontra principalmente em torno da intrusão AP1.

A mineralização de ouro no grupo pórfiro Marmato é epitermal e do tipo vênula em profundidade, e é estruturalmente controlado por veios e vênulas com orientações NW e WNW (Figura 6). Na zona superior (Epitermal) o depósito é composto principalmente de veios com quartzo, carbonato, pirita, arsenopirita, marmatita, pirrotita, calcopirita e ouro electrum (Figura 6-Figura 7), enquanto na zona inferior (em vênulas) o depósito é composto de quartzo, pirrotita, calcopirita, pirita, minerais de bismuto e ouro livre (Figura 6 e Figura 8). Uma alteração propilítica regional se apresenta de forma pervasiva, e é sobre imposta principalmente pelas alterações argílica e fílica em zonas proximais aos veios mineralizados, e uma fraca alteração potássica (biotita secundaria) em profundidade (Figura 7-Figura 8). A mineralização se estende por mais de $1.250 \mathrm{~m}$ na vertical e se encontra ainda aberta em profundidade (Figura 6).

O grupo de pórfiro Aguas Claras mostra alteração potássica penetrante e um estilo de mineralização de baixo grau do tipo pórfiro Au-Cu-Mo. Alguns poucos furos de sondagem mostram interceptos interessantes (87.9 m com 0.118g/t Au e 53.9 m com 0.377g/t Au, com baixos graus de $\mathrm{Cu}$ (máximo 1.737 ppm), Mo (máximo 308 ppm) e Ag (máximo 438 ppm). Não sem tem recursos minerais de Águas Claras. 


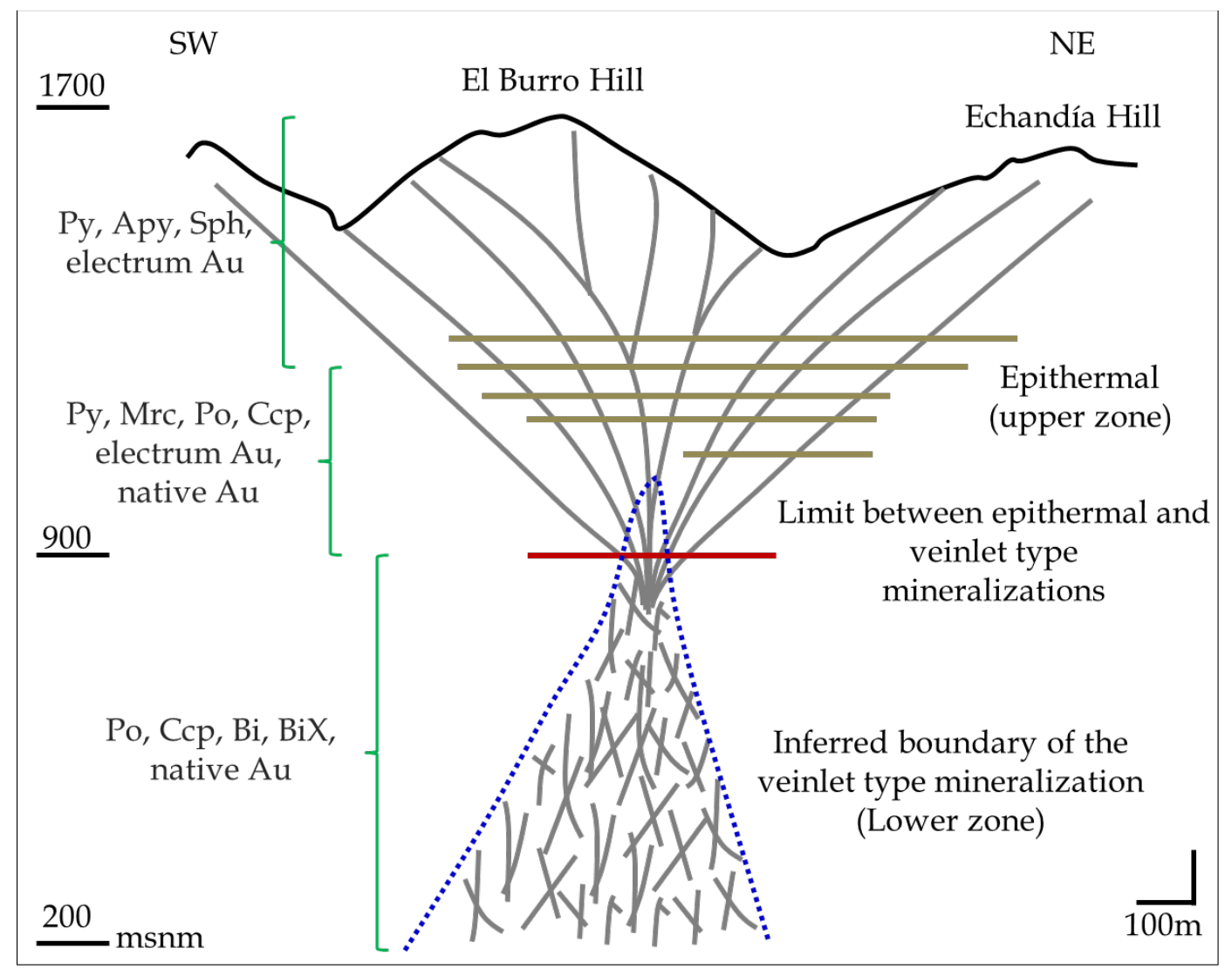

Figura 6. Perfil do depósito de Marmato (Modificado a partir de Gran Colombia Gold Corp.) no qual pode se observar duas zonas principais. A zona superior caracterizada por veios com sulfetos do tipo epitermal e uma zona inferior com uma ocorrência em tipo vênulas, ambos com quase 700 metros de extensão vertical. Um zoneamento de sulfetos ocorre a partir da parte superior para a zona inferior do sistema na medida em que a finura do ouro aumenta. A associação mineral na zona inferior do depósito é notável pela presencia de Po, Сср, Bi, BiX e ouro nativo. As linhas douradas na zona superior fazem referência a diferentes níveis para a extração de ouro. Py: Pirita; Ccp: Calcopirita; Po: Pirrotita; Apy: Arsenopirita; Sph: Esfalerita (Marmatita); Mrc: Marcasita: Bi: Bismuto; Bix: Minerais de bismuto; Au: Gold. 

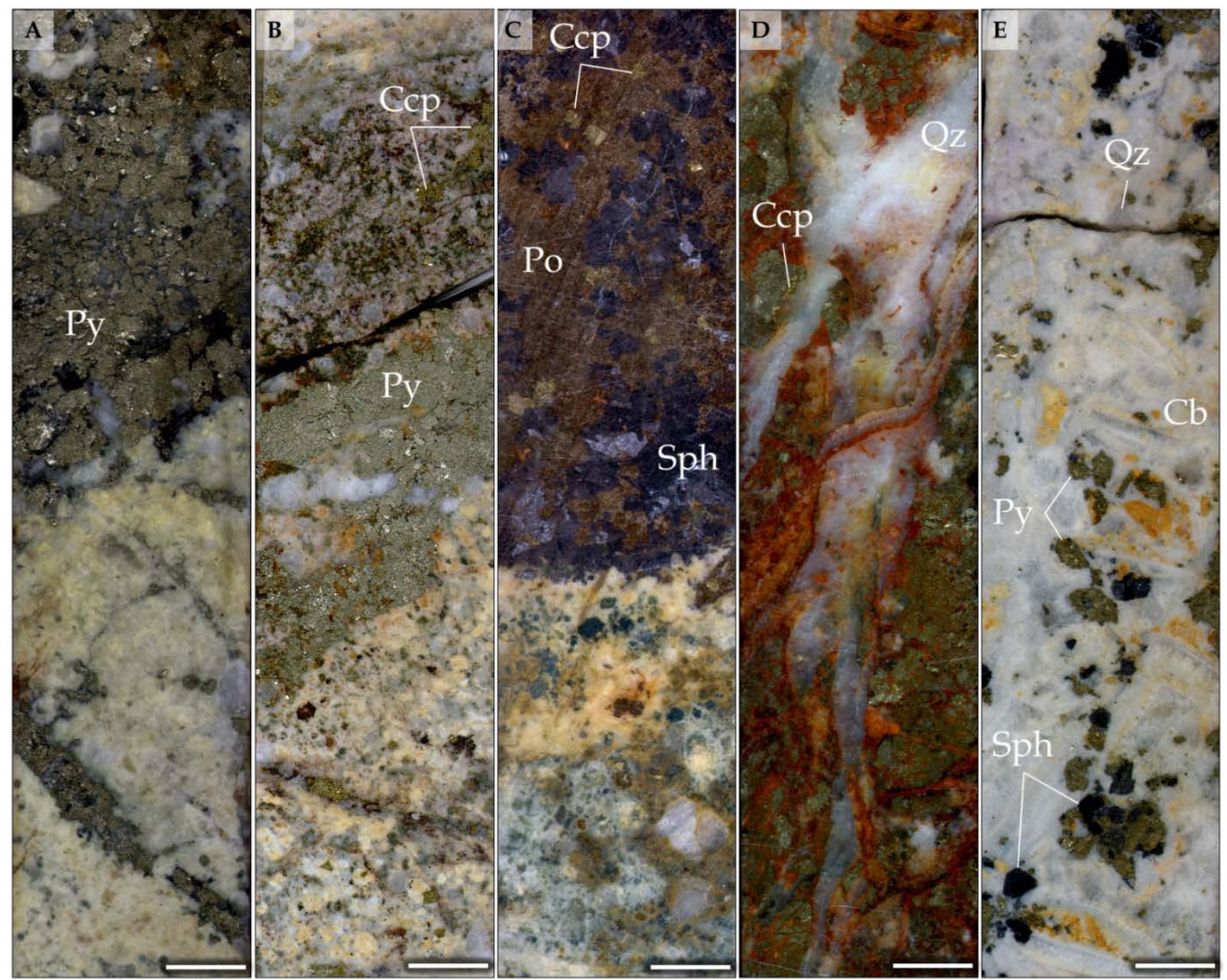

Figura 7. Rochas de veios no Marmato em amostras de mão (zona superior). A. Veios com pirita e quartzo maciço em contato com o dacito pórfiro P1 que mostra um fraco halo de alteração com sericita e argílica na borda da rocha encaixante, B. Veio zoneado com calcopirita no centro e pirita em contato com a rocha encaixante com um fraco halo de alteração com sericita e argílica, C. Veio com pirrotita e esfalerita (Marmatita) massivas e pouca calcopirita, com duas zonas de alteração na borda da rocha encaixante desde uma fraca sericita e argílica no limite com o veio para um halo com alteração propilítica, D. Calcopirita maciça com alguns óxidos-hidróxidos associados e quartzo em bandas. E. Veio de carbonato com pouco quartzo e com esfalerita (Marmatita) e pirita. A espessura dos veios pode ser de até 2 metros. Py:

Pirita; Sph: Sphalérita (Marmatita); Ccp: Calcopirita; Po: Pirrotita; QZ: Quartzo; Cb: Carbonato. A escala é um (1) centímetro. 

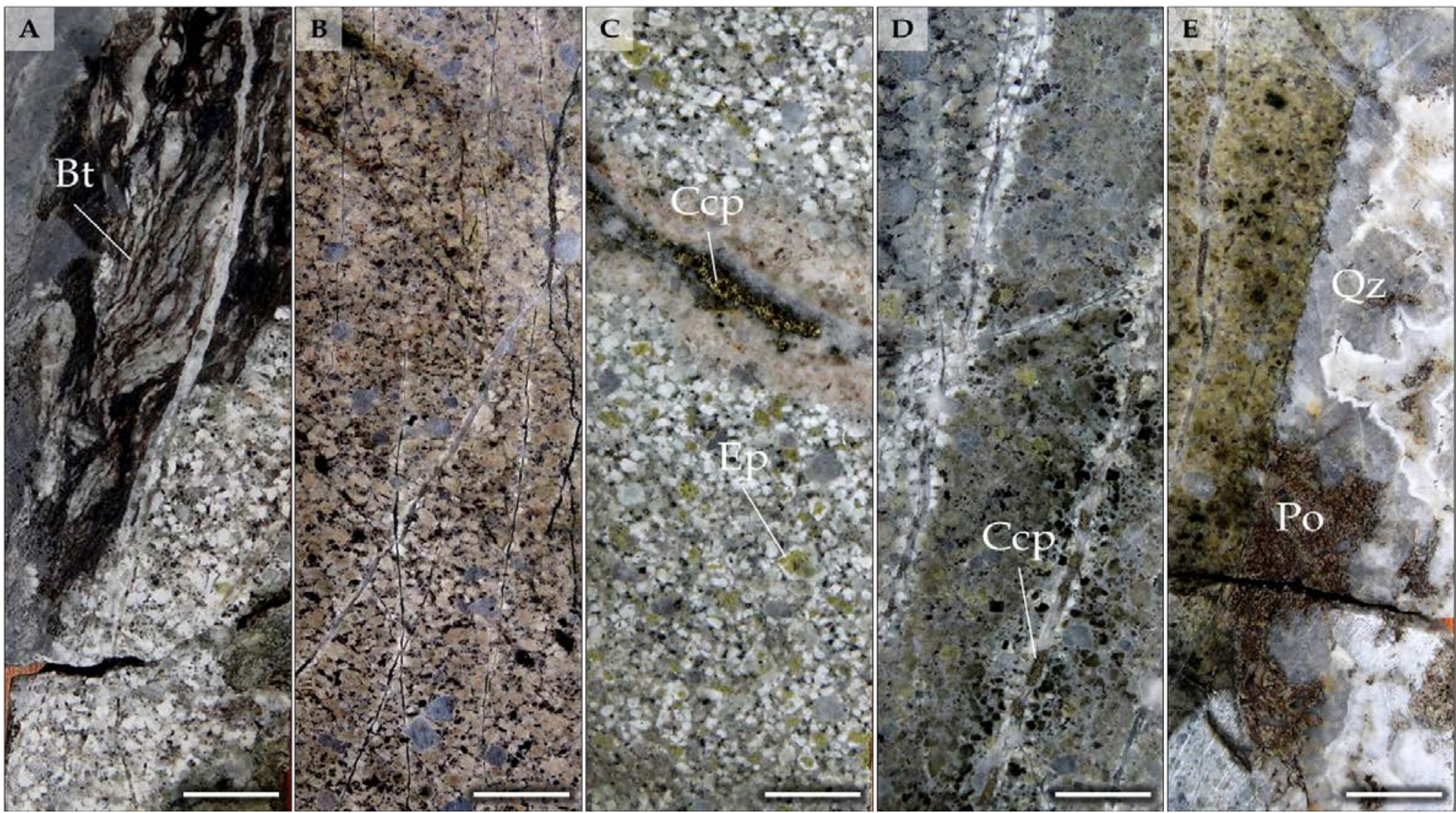

Figura 8. Rochas com vênulas no Marmato em amostras de mão (zona inferior). O sistema inferior no Marmato mostra principalmente vênulas, no entanto alguns veios também são exibidos e a sua espessura pode ser de até 10 centímetros A. Dacito pórfiro P1 em contato com xistos grafitosos (Arquia Complex) com tons marrons em juntas rochas gerado pela presença de biotita hidrotermal (alteração potássica). B. Vênulas de quartzo com pouca pirrotita desenvolvidas no dacito pórfiro P1 com alteração potássica. C-D. Calcopirita e quartzo com pouca pirrotita numa vênula com halo de alteração de feldspato branco e esmectita-ilita atravessando o dacito pórfiro P1. E. Veio de quartzo com bandeamento e texturas (Cockscomb e colloform) junto com pirrotita e pouca calcopirita atravessando o dacito pórfiro que apresenta alterações propilítica e esmectita-ilita. Ccp: Calcopirita; Po: Pirrotita; Qz: Quartzo; Bt: Biotita hidrotermal. A escala é um (1) centímetro. 


\section{CAPÍTULO 3: MÉTODOS ANALÍTICOS}

Vinte e seis amostras correspondentes às rochas porfiríticcas com menor alteração foram coletadas a partir de núcleos de perfuração de Gran Colombia Gold Corp., no Marmato e Echandia Hills (principalmente nos corpos pórfiricos P1-P5) e na zona de Aguas Claras (corpos pórfiricos intimamente relacionados AP1-AP5) (Figure 3).

\subsection{PETROGRAFIA}

Amostras com pouca alteração, das diferentes intruções porfiríticas, no depósito de Marmato foram analisadas para fins de petrografia ígnea. Um total de 26 seções finas foram utilizados para a contagem de pontos. As análises modais foram classificadas de acordo com o triângulo QAP para rochas plutônicas e saturados em sílica de (Le Maitre, 2002).

\subsection{MICROANÁLISES DE SONDA ELETRÔNICA - (EPMA)}

Um total de 93 EPMA análises foram realizados nos cristais de ilmenita e magnetita, a partir das intrusões na MACS, na Universidade de Brasília e na Universidade Nacional da Colômbia, com uma microssonda eletrônica JEOL JXA-8500 e uma SuperProbe JEOL JXA-8230, respectivamente, ambas com a capacidade de mapeamento de área por XRM e imagens a partir de elétrons retro-dispersados. As medições foram feitas com uma fonte primaria de laser $\mathrm{W}^{6+}$ com aproximadamente $20-85 \mathrm{nA}$ a $20 \mathrm{KeV}$. O diâmetro do laser de íon primário foi de $1-5 \mu \mathrm{m}$.

\subsection{LITOGEOQUÍMICA}

Análises litogeoquímicas foram obtidos nos laboratórios ACME, Canadá, por meio de técnicas combinadas de ICP-ES e ICP-MS, com digestão ácida múltipla, após a fusão de borato de lítio para elementos maiores e traços, com exceção dos metais base, os quais foram extraídos por água-régia. A técnica Lecco foi usada para o S e C total. Os analises foram realizadas nas mesmas amostras de petrografia, as quais foram recolhidas nas zonas com menor alteração e perto da mineralização, mas longe de veios, tentando-se evitar os efeitos da alteração. A precisão das análises (determinadas a partir de análises com padrões internacionais e duplicatas) é dentro de $5 \%$ em relação aos elementos maiores, e dentro do $10 \%$ relativo para elementos menores e traços. Para fins da plotagem, todas as composições de óxido maiores foram normalizadas para uma base livre de voláteis.

\subsection{GEOCRONOLOGIA}

Análises geocronológicas foram realizadas no Laboratório de Geocronologia da Universidade de Brasília. Cristais de zircões correspondentes a dez rochas porfiríticas icom pouca alteração, foram analisados. As amostras foram esmagadas usando tanto uma mandíbula, como uma trituradora de ágata, e, em seguida peneiradas para se obter a fracção 
com o tamanho desejado $(125-300 \mu \mathrm{m})$. Os grãos de zircão foram concentrados usando-se uma bateia e um separador magnético Frantz foi usado para remover os minerais magnéticos na fracção mineral pesada. A purificação final de zircão foi realizada por seleção manual. Os zircões foram analisados por LA-MC-ICP-MS seguindo a metodologia proposta por Bühn et al. (2009). As análises foram realizadas utilizando um tamanho do ponto de $30 \mu \mathrm{m}$ e o fraccionamento induzido pelo laser na relação ${ }^{206} \mathrm{~Pb} /{ }^{238} \mathrm{U}$ foi corrigido usando o método de regressão linear de Koesler et al. (2002).

Análises Ar/Ar foram realizadas no OSU Argon Geocronologia Lab. Cristais de adularia, a partir de um veio hidrotermal (zona superior) e uma vênula (zona inferior), foram analisados por um espectrômetro de massa com coletores múltiplos Thermo Scientific ARGUS VI.

\subsection{ISÓTOPOS SR-ND}

Análises isotópicas Sr-Nd para rocha total foram realizadas no Laboratório de Geocronologia da Universidade de Brasília, Brasil. Os métodos aplicados para as análises Sr-Nd neste estudo foram os mesmos que os descritos por Gioia \& Pimentel (2000). As amostras foram quebradas por martelo, trituradas num britador de mandíbulas, descartandose fragmentos de rocha com características visíveis de alteração atmosférica/hidrotermais; posteriormente, lavou-se em água deionizada, lixiviando por 25-30 minutos em $1 \mathrm{~N}$ quente de $\mathrm{HCl}$ destilado, em uma caixa de ultrassom.

A separação de Sm-Nd foi realizada usando colunas de intercambio catiônico, após as fracções obtidas serem evaporadas com duas gotas de $0.025 \mathrm{~N}$ H3PO4. O resíduo foi dissolvido em $1 \mathrm{ml}$ ao 5\% de HNO3 destilado e carregado em um conjunto de filamentos duplo de Re. O espectrômetro de massa usado foi um Finnigan MAT 262 com 7 coletores, com análises realizadas no modo estático. Incertezas para 147Sm / 144Nd e 143Nd /144Nd foram melhores do que $\pm 0,2 \%(2 \sigma)$ e $\pm 0,0045 \%(2 \sigma)$, respectivamente, com base na análise do padrão de rocha internacional BHVO-1. A razão $143 \mathrm{Nd} / 144 \mathrm{Nd}$ foram normalizados utilizando $146 \mathrm{Nd} / 144 \mathrm{Nd}=0,7219$ e a constante de decaimento empregada foi 6,54 × 10-12 y-1 (Lugmair \& Marti, 1978).

Para as análises de isótopos de Sr, a metodologia utilizada foi após digestão ácida e separação em colunas de intercambio catiônica, as fracções enriquecidas em Sr foram depositadas junto com $1 \mathrm{ml}$ de H3PO4, dentro de um filamento de Ta, em um espectrômetro de massa Finnigan MAT 262. Com base na análise da norma internacional NBS987, as incertezas da razão $87 \mathrm{Sr} / 86 \mathrm{Sr}$ foram melhores do que $\pm 0,0036 \%(2 \sigma)$. A constante de decaimento do Rb utilizada foi a partir de (Nebel e col., 2011) com um valor de 1,393 × 10$11 \mathrm{y}-1$. 


\title{
CAPITULO 4: “GEOCHRONOLOGY, GEOCHEMISTRY AND
}

OXIDES CARACTERIZATION OF THE MARMATO GOLD DEPOSIT, COLOMBIA: IMPLICATIONS FOR MINERALIZATION AND REGIONAL EXPLORATION".

${ }^{1}$ SANTACRUZ, R. L., ${ }^{2}$ MATTEINI, M., ${ }^{3}$ BOTELHO, N. F., ${ }^{4}$ REDWOOD, S., ${ }^{5}$ MOLANO, J. C., \& ${ }^{6}$ CECCHI, A.

\author{
${ }^{1}$ MSc Student, Brasilia University, Brasilia, Brazil. \\ lsantacruzr@unal.edu.co \\ ${ }^{2}$ Professor Earth Science Department, Brasilia University, Brasilia, Brazil. \\ massimo@unb.br \\ ${ }^{3}$ Professor Earth Science Department, Brasilia University, Brasilia, Brazil. \\ nilsonfb@unb.br \\ ${ }^{4}$ Consulting Geologist, Panama City, Panama \\ mail@sredwood.com \\ ${ }^{5}$ Professor Earth Science Department, National University of Colombia, Bogotá, Colombia. \\ jcmolanom@unal.edu.co \\ ${ }^{6}$ VP of Exploration, Gran Colombia Gold Corp., Medellin, Colombia. \\ acecchi@grancolombiagold.com
}

\begin{abstract}
4.1 Abstract
The Marmato gold deposit is located in one of the premier mineral provinces of Colombia, the Middle Cauca belt, associated with a late Oligocene to late Miocene volcanic arc. The Marmato and Aguas Claras suite (MACS) hosted and epithermal to veinlet at deep gold mineralization in the Marmato group and a porphyry gold mineralization in the Aguas Claras group.

MACS dated between ( $6.58 \pm 0.07$ Ma to $5.74 \pm 0.14 \mathrm{Ma}$, U-Pb LA-ICP-MS in zircon). Epithermal to veinlet at depth related hydrothermal adularia yielded a weighted plateau ${ }^{40} \mathrm{Ar} /{ }^{39} \mathrm{Ar}$ age of $(6.05 \pm 0.02)$ Ma to $(5.96 \pm 0.02)$ Ma, for two samples, which are between the age of pre and pos-mineralization Marmato porphyry intrusions.

The MACS is mainly composed by andesite to dacite rocks, calc-alkaline to high $\mathrm{K}$ calcalkaline, oxidized type - magnetite series with high Mn-ilmenite contents and low magnetite, characterized by an "adakite-like" signature with relatively high $\mathrm{Sr} / \mathrm{Y}(>55)$, low $\mathrm{La} / \mathrm{Yb}(<20), \mathrm{Mg} \#<0.5$, and $\left(\mathrm{Dy}_{\mathrm{N}} / \mathrm{Yb}_{\mathrm{N}}\right)<1.5$. Geochemistry and Sr-Nd isotopic compositions suggest a magma generated by partial melting of the mantle wedge followed by minimal crustal contamination and crystal fractionation at high $\mathrm{fO}_{2}$ - hydrous
\end{abstract}


conditions. Compositional similarities between the MACS and spatially associated intrusions with gold deposits in Colombia mostly reflect similar regional-scale process for the generation of productive intrusions through the late Miocene after a prolonged period of arc magmatism that began in the late Oligocene (and is still active).

Magmatic Mn-ilmenite bearing rocks not just suggest high $\mathrm{fO}_{2}$ in the magma, but also along with hydrothermal pyrrhotite characterized the Marmato epithermal to veinlet at depth $\mathrm{Au}$ mineralization and generate medium low susceptibility values and natural remanent magnetization (NRM) intensities. This highlight the importance of this type of deposits as interesting targets for exploration in the late Miocene volcanic arc in Colombia, in addition to those with typical associated magmatic-hydrothermal bearing magnetite (disseminate/veinlets).

\subsection{Introduction}

THE MARMATO gold deposit is located on the eastern flank of the Western Cordillera of Colombia (roughly $45 \mathrm{~km}$ north of the city of Manizales, Caldas Department). Exploration work by Gran Colombia Gold Corp., has defined open pit resources estimated at $11.8 \mathrm{Moz}$ $\mathrm{Au}$ and $80.3 \mathrm{Moz} \mathrm{Ag}$ in 409.7 Mt with grades of $0.9 \mathrm{~g} / \mathrm{t} \mathrm{Au}$ and $6.1 \mathrm{~g} / \mathrm{t} \mathrm{Ag}$ in the measured and indicated categories, plus 2.60 Moz Au and 9.4 Moz Ag in 79.10 Mt with grades of $1.02 \mathrm{~g} / \mathrm{t} \mathrm{Au}$ and $3.7 \mathrm{~g} / \mathrm{t} \mathrm{Ag}$ in the inferred category, based on a cut-off grade of $0.3 \mathrm{~g} / \mathrm{t} \mathrm{Au}$ and a gold price of \$1,400 per ounce for a total of $496 \mathrm{Mt}$ containing 15.0 Moz Au and 90.0 Moz Ag (Parsons, 2012). Past production is estimated to have been between 1.75 and 2.25 Moz Au over two and a half millenia (Redwood, 2011).

The Marmato gold deposit consists of a structurally controlled epithermal vein system with a mineral assemblage dominated by pyrite, arsenopyrite, marmatite, pyrrhotite, chalcopyrite and electrum gold (upper zone) and a veinlet type system with a mineral assemblage dominated by pyrrhotite, chalcopyrite, bismuth minerals and free gold (lower zone), associated with the late Miocene Marmato and Aguas Claras suite (MACS) located at southern part of the Marmato stock.

The marmato stock is an elongated N-S body (18 km long and $3 \mathrm{~km}$ wide) emplaced during the late Miocene to early Pliocene (Aspden et al., 1987; Tassinari et al., 2008) that hosts the Marmato and Aguas Claras gold mineralization of epithermal and porphyry type similar to others Miocene gold deposits located in the middle Cauca valley (Sillitoe et al., 1982; Sillitoe and Hart, 1984; Rodriguez and Warden, 1993; Sillitoe, 2008; Leal-Mejía, 2011; Lesage et al., 2013). Some previous studies have been carried out of the Marmato mineralization (Bedoya, 1998; Rossetti and Colombo, 1999; Tassinari et al, 2008; Santacruz, 2011) although none of them have carried out a complete dating program nor 
considered the role of litho-geochemistry and oxides chemistry in the generation and characterization of the deposit.

Our aim is to constrain the age of the magmatism and mineralization in the Marmato gold deposit and the petrogenetic evolution of the MACS to evaluate the metallogenetic implications of these parameters and contribute to the regional exploration in the late Miocene magmatic arc in Colombia. We present a data set of (U-Pb) LA-ICP-MS and $\left({ }^{40} \mathrm{Ar}-{ }^{39} \mathrm{Ar}\right)$ dating, geochemical and isotopic composition of the mineralized porphyry intrusions in the Marmato and Aguas Claras suite (MACS), and electron probe microanalyzer data for oxides. Finally we compare it to the related gold deposits of La Colosa and Buritica.

\subsection{Regional Geologic Setting}

The Colombian Andes are include in the Northern Andean Block, which include the north volcanic zone (NVZ) (Gansser, 1973; Shagam, 1975) (Figure 1 A-B), and comprise three N to NNE trending mountain ranges, the Western, Central and Eastern Cordilleras, separated by two major depressions, the Cauca-Patía and Magdalena from west to east, which represent terrane boundaries (Figure 2 A). The Colombian Andes have a complex history of volcanism, subduction, accretion and faulting, represented by the juxtaposition of metamorphic, igneous and sedimentary rocks of various ages from the Precambrian to the

present (Aspden et al., 1987; Restrepo and Toussaint, 1988; Taboada et al., 2000; Pindell and Kennan, 2009). 


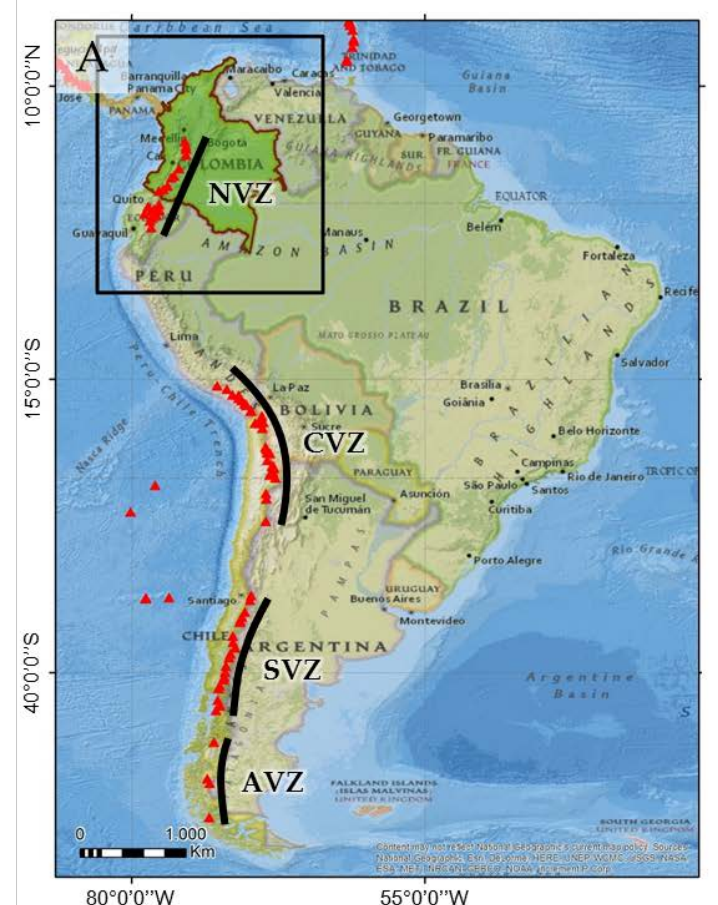

$80^{\circ} 0^{\prime} 0^{\prime \prime} \mathrm{W}$

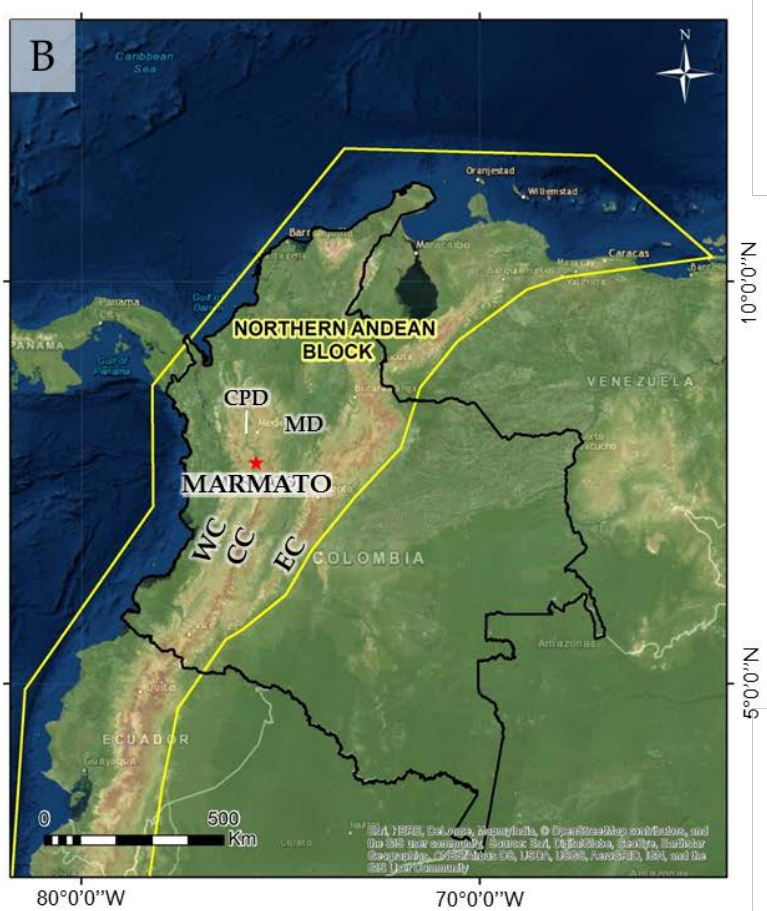

$80^{\circ} 0^{\prime} 0^{\prime \prime} \mathrm{W}$

$70^{\circ} 0^{\prime} 0^{\prime \prime} \mathrm{W}$

Figure 1 A. Volcanic zones of South America. NVZ: North volcanic zone; CVZ: Central Volcanic Zone; SVZ: Sothern Volcanic Zone; AVZ: Austral Volcanic Zone. B. Northern Andean Block comprising the Colombian Andes. WC: Western Cordillera; CC: Central Cordillera; EC: Eatern Cordillera; CPD: Cauca-Patia Depression; MD: Magdalena Depression.

In order to explain the complex geology setting of Colombia, (Cediel et al., 2011) have proposed nine principal tectonic realms which can comprise at the same time different terranes: 1) Guyana shield; 2) Maracaibo sub-plate; 3) Central continental sub-plate; 4) Pacific terranes; 5) Caribbean terranes; 6) Choco-Panama arc; 7) Guajira terrane; 8) Caribbean Plate; 9) Nazca Plate (Figure 2 A).

Marmato is located on the eastern side of the Western Cordillera which is separated from the Central Cordillera to the east by the River Cauca and lies within the Romeral terrane bounded by the Cauca Fault (West) and by the Romeral Fault (East) and is part of the Pacific terranes realm (Figure $2 \mathrm{~B}$ ). In this paper only a summary of the Western Cordillera geology around Marmato is presented. Detailed Colombian geological descriptions include Campbell (1974), Shagam (1975), Etayo et al. (1983), Cediel and Cáceres (2000), Cediel et al. (2003), Cáceres et al. (2003), Cediel et al., (2011) and Gómez et al. (2015). 

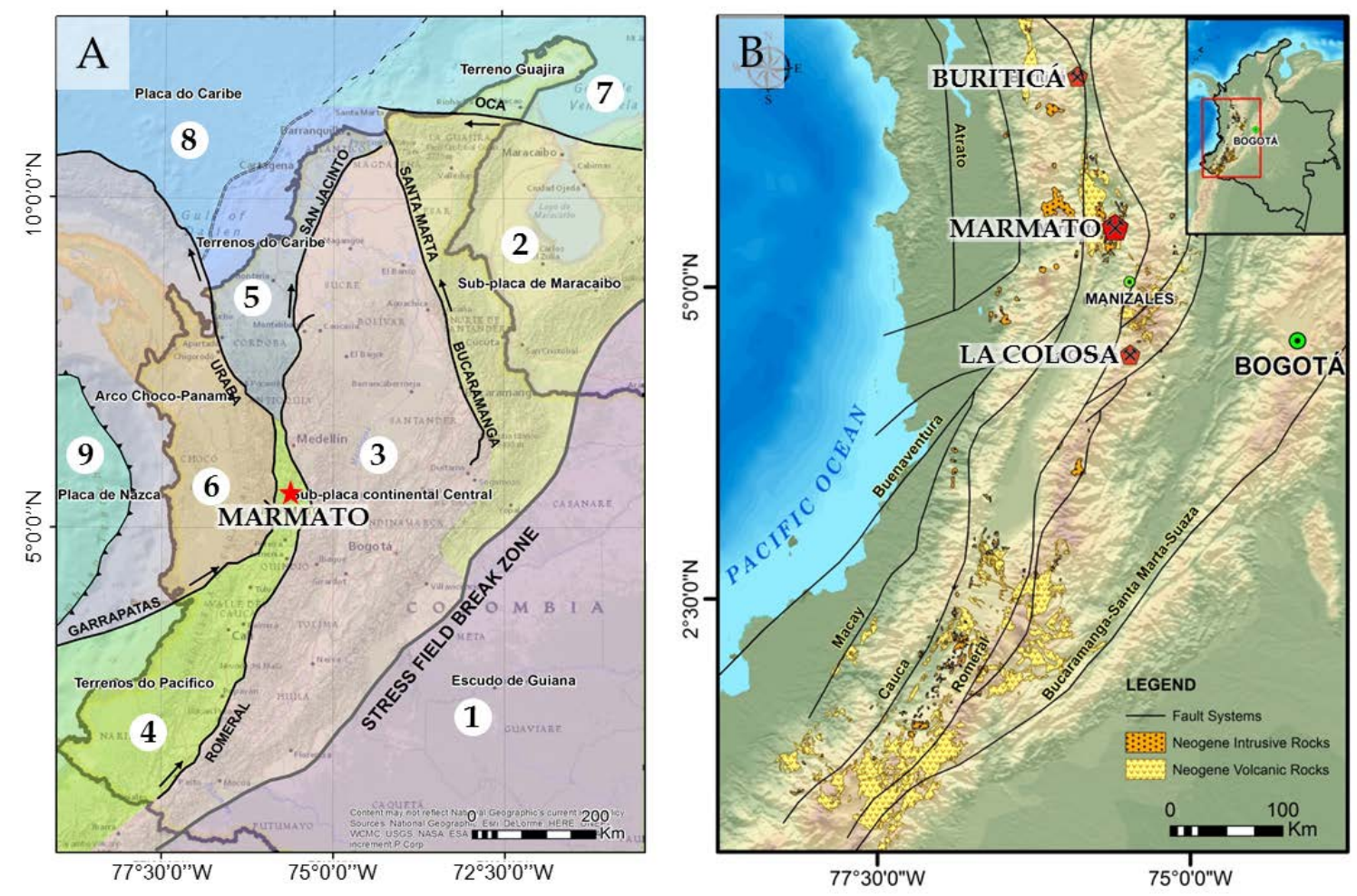

Figure 2 A. Principal tectonic realms of Colombia (Modified from Cediel et al., 2011): 1) Guyana shield; 2) Maracaibo sub-plate; 3) Central continental sub-plate; 4) Pacific terranes; 5) Caribbean terranes; 6) Choco-Panama arc; 7) Guajira terrane; 8) Caribbean Plate; 9) Nazca Plate B. Neogene (mostly late Oligocene to late Miocene) magmatic rocks over the Colombian Andes. Modified from Geological map of Colombia (Geological Colombian Survey, 2015). Deposits of Marmato, La Colosa and Buritica over the Middle Cauca Valley gold belt.

The Romeral terrane is an oceanic terrane comprising metamorphosed mafic to ultramafic complexes, ophiolite sequences and oceanic sediments of probable Late Jurassic to Early Cretaceous age (Cediel and Cáceres, 2000; Cediel et al., 2003). This was accreted to the continental margin, which now forms the Central Cordillera along the Romeral Fault, which lies east of the River Cauca, in the Aptian (125 to 110 Ma). Movement on the Romeral Fault was dextral (Cediel and Cáceres, 2000; Cediel et al., 2003) indicating that terrane accretion was highly oblique from the south-west. These rocks form the country rock of the Marmato stock and include metabasalts, amphibolites, serpentinites, graphitic schist, biotite schist, sericite schist and chlorite schist that are called the Arquía Complex (Calle et al., 1984; Durán et al., 2005). The Romeral Fault zone is marked by dismembered ophiolitic rocks, including glaucophane schist, in a tectonic melange and is interpreted as a terrane suture marking an old subduction zone.

The Romeral terrane is bounded on the west side by the Cauca Fault and is partially covered by continental sediments of the Oligocene to Lower Miocene age Amagá Formation, comprising gray to green coloured conglomerates, sandstones, shales and coal 
seams, which are overlain by thick volcanic and sedimentary rocks of the Late Miocene Combia Formation, divided into a Lower Member of basalt and andesite lava flows, agglomerates and tuffs, and an Upper Member of conglomerates, sandstones and tuffs (Durán et al., 2005). Further west, additional oceanic and island arc terranes were subsequently accreted to the Western Cordillera in the Paleogene and Neogene Periods, culminating in the on-going collision of the Panamá-Choco arc since the late Miocene. This reactivated the Cauca and Romeral Faults with left lateral and reverse movements (Cediel and Cáceres, 2000; Cediel et al., 2003). The crustal thinning and reactivation of the Romeral and Cauca faults triggered by the accretion of the Panamá-Choco block onto the Western Cordillera around 12 Ma allowed Late Miocene intrusions along the middle Cauca valley (Duque-Caro, 1990; Ego and Sebrier, 1995; Tassinari et al, 2008).

The recent tectonic setting of the Colombian Andes is characterized by subduction of young ( $<20 \mathrm{Ma})$ oceanic crust (Ramos and Folguera, 2009) beneath relative thin continental crust $(<40 \mathrm{Km})$ (Cediel and Caceres, 2000; Cediel et al., 2003). Benniof zone is located around 140-200 Km under the volcanic belt in the Colombian Andes which has remained almost the same during the last 10Ma (Pennington, 1981; James \& Murcia, 1984; Gustscher et. al., 1999 and Vargas \& Mann, 2013). The Marmato stock is part of Miocene magmatism (Figure 2B) characterized by calc-alkalic subvolcanic intrusions and volcanic rocks of the Combia Formation. Miocene magmatism cross-cut the units of the Romeral terrain, the plutonic units of the Albian and early Cenozoic, and siliciclastic sequences of the Amagá Formation deposited in a pull-apart basin (Restrepo et al., 1981; Cáceres et al. 2003; Tassinari et al, 2008). Miocene gold related magmatism in Colombia has been wellrecognized in the Western and Central Cordilleras associated with batholiths and stocks (Sillitoe et al., 1982; Alvarez, 1983; Sillitoe and Hart, 1984; Aspden et al., 1987; Toussaint and Restrepo, 1988; Rodriguez and Warden, 1993; López et al., 2006; Sillitoe, 2008; Lodder et. al, 2010; Leal-Mejía, 2011; Lesage et al., 2013) (Figure 2B). Further, late Miocene-Pliocene magmatism has also been recognized in the Santander Massif in the northern part of the Eastern Cordillera (Mantilla et al., 2009) with related gold mineralization.

\subsection{Local Geologic Setting}

The Marmato gold deposit is hosted by the andesite to dacite Marmato porphyry stock which is $18 \mathrm{~km}$ long and 3 to $6 \mathrm{~km}$ wide and is elongated north to south (Calle et al., 1984). It intrudes the Arquía Complex and Amagá Formation on the east side in the Cauca Valley, and it is part of the Combia Formation on the west side. The Marmato gold deposit is hosted by a set of porphyry bodies which comprises a stock with dimensions of about 3.0 km NS by 1.6-2.5 km wide near the southern end of the larger Marmato stock. Five main 
porphyry pulses have been identified in the Marmato gold deposit, named P1 to P5 from oldest to youngest (the Marmato porphyry group) (Figure 3-Figure 4). The ages of the intrusions have been reported previously between 7.1 \pm 0.2 Ma (Rodrigues, 1987, quoted in Rodrigues and Warden, 1993) to 6.3 \pm 0.7 Ma (Gonzalez, 1980, quoted in: Sillitoe et al., 1982), both by the K-Ar method. A geographic separate porphyry group with five porphyry pulses, named AP1 to AP5 from oldest to youngest (Aguas Claras porphyry group), occurs $3 \mathrm{~km}$ southwest of the Marmato porphyry group (Figure 3 and Figure 5). Two intrusions of the Marmato group, P3 and P5, cross-cut the Aguas Claras group in a dike-like. There is no previous dating of the Aguas Claras porphyry group.

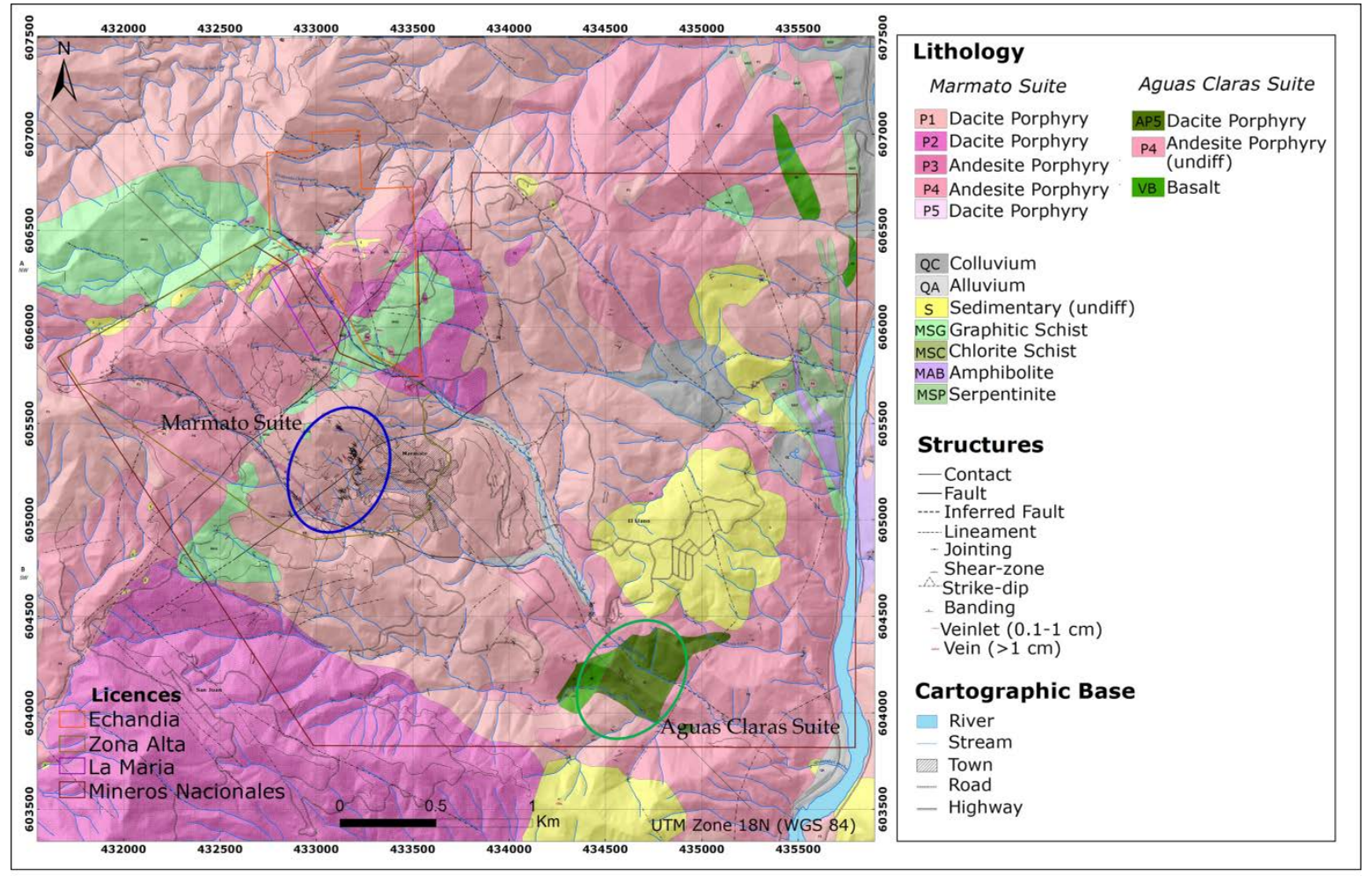

Figure 3 Local geological map superimposed on a DEM background of the Marmato gold deposit. Gran Colombia Gold Corp. 


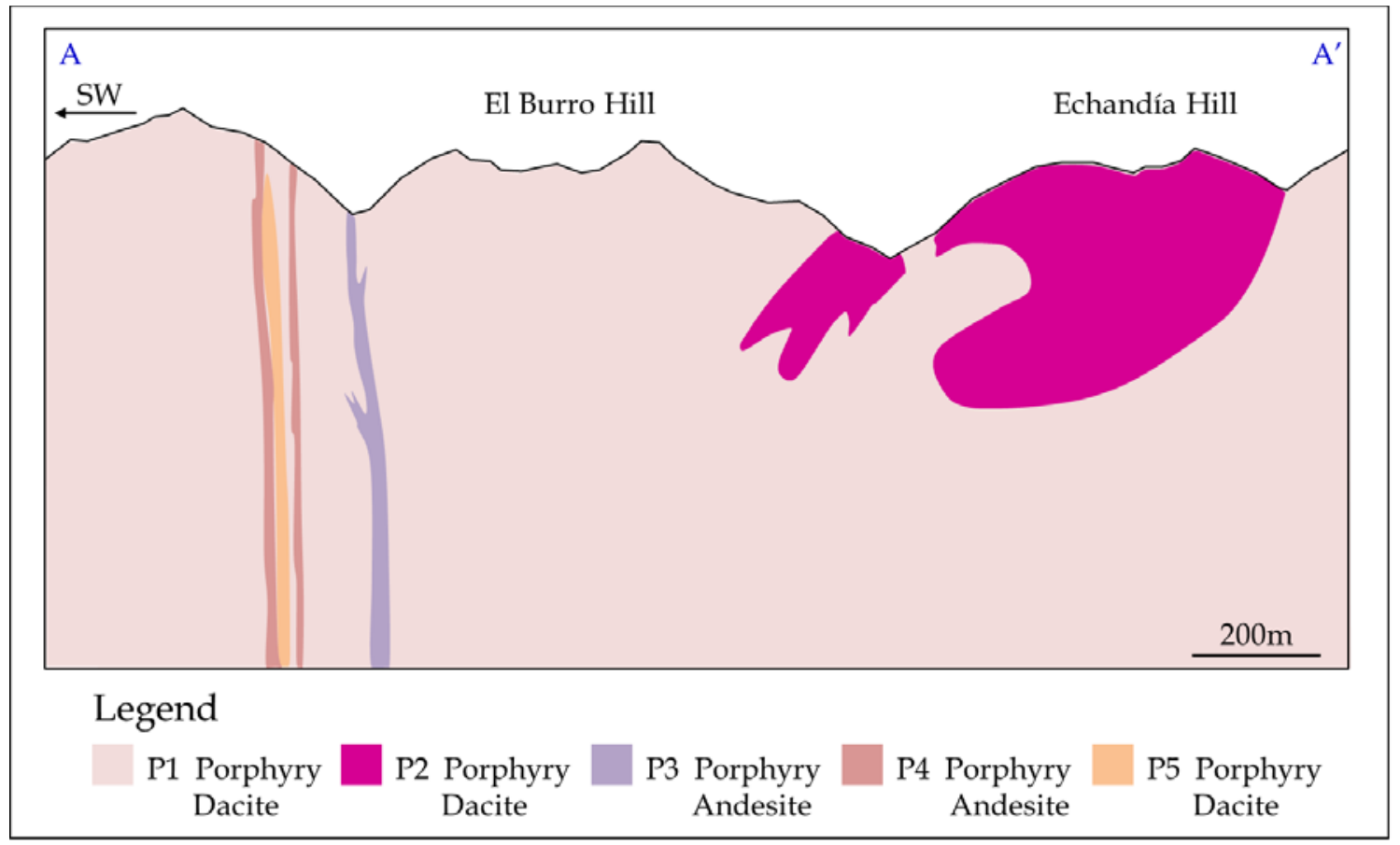

Figure 4. Schematic profile showing the occurrence of intrusions P1 to P5 in the Marmato gold deposit. Marmato gold deposit is develop mainly under the El Burro hill and SW of the Echandía hill.

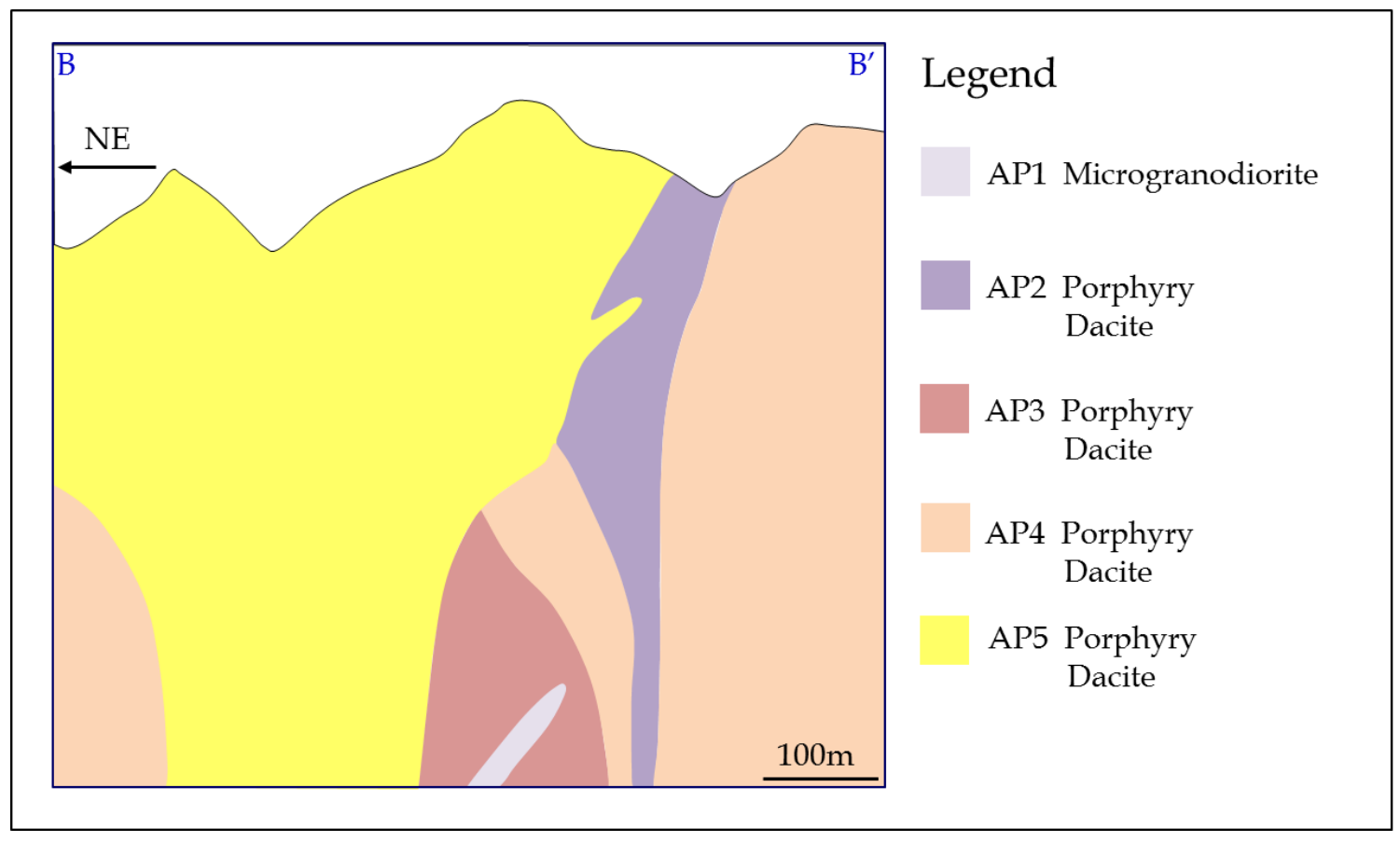

Figure 5. Schematic profile showing the occurrence of intrusions AP1 to AP5 in the Aguas Claras deposit. Aguas Claras deposit is located mainly around intrusion AP1. 
Gold mineralization in the Marmato porphyry group is epithermal and veinlet type at depth and structurally controlled in veins and veinlets with dominant NW and WNW trends (Figure 6). The deposit mainly comprises sulfide-rich veinlets and veins composed of quartz, carbonate, pyrite, arsenopyrite, marmatite, pyrrhotite, chalcopyrite and electrum gold (epithermal upper zone) (Figure 6-Figure 7), and quartz, pyrrhotite, chalcopyrite, bismuth minerals and free gold (veinlet type at lower zone) (Figure 6 and Figure 8). Pervasive early propylitic alteration is over-printed principally by phyllic and intermediate argillic alteration related to the gold mineralized veins, with weak potassic (biotite) alteration at depth (Figure 7-Figure 8). Mineralization extends over 1,250 m vertically and is open at depth (Figure 6).

The Aguas Claras porphyry group shows pervasive potassic alteration and low grade porphyry style Au-Cu-Mo mineralization. Limited drilling has given intersections up to $87.9 \mathrm{~m}$ at $0.118 \mathrm{~g} / \mathrm{t} \mathrm{Au}$ and $53.9 \mathrm{~m}$ at $0.377 \mathrm{~g} / \mathrm{t} \mathrm{Au}$, with low grades of $\mathrm{Cu}$ (maximum sample grade 1,737 ppm), Mo (maximum sample grade $308 \mathrm{ppm}$ ) and Ag (maximum sample grade $438 \mathrm{ppm}$ ). There is no mineral resource for Aguas Claras. 


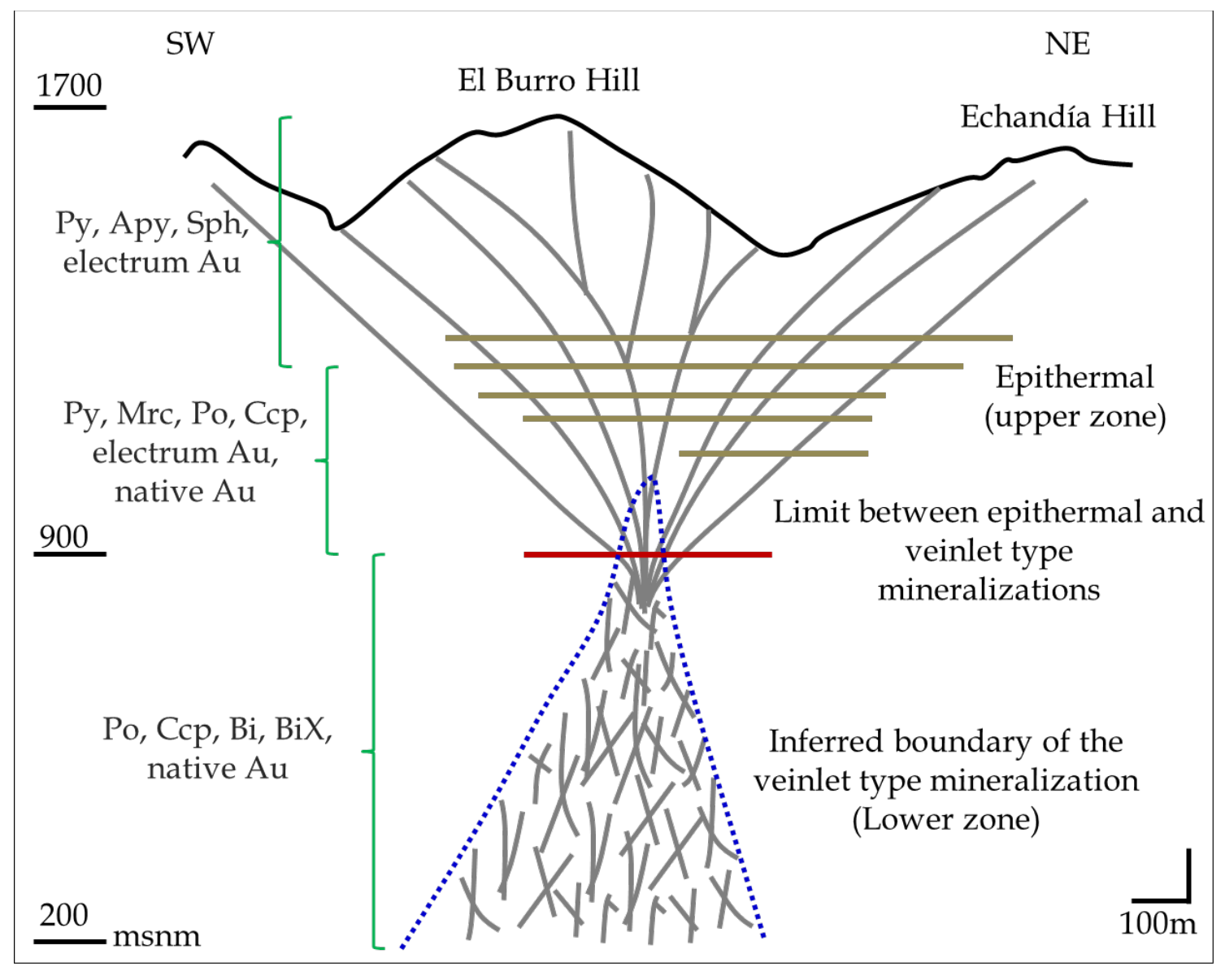

Figure 6. Marmato deposit section (Modified from Gran Colombia Gold Corp.) showing the two principal zones. Upper zone characterized by epithermal sulfide veins and lower zone with a veinlet type occurrence, both with almost 700 meters of vertical extension. Sulfide zonation occurs from the top to the lower zone of the system as gold increase their fineness. Mineral association at lower zone of the deposit is remarkable by the association of Po, Ccp, Bi, Bix and native gold. Golden lines in the Upper zone make reference to diferent levels for gold extraction. Py: Pyrite; Ccp: Chalcopyrite; Po: Pyrrhotite; Apy: Arsenopyrite; Sph: Sphalerite (Marmatite); Mrc: Marcasite: Bi: Bismuth; BiX: Bismuth minerals; Au: Gold. 

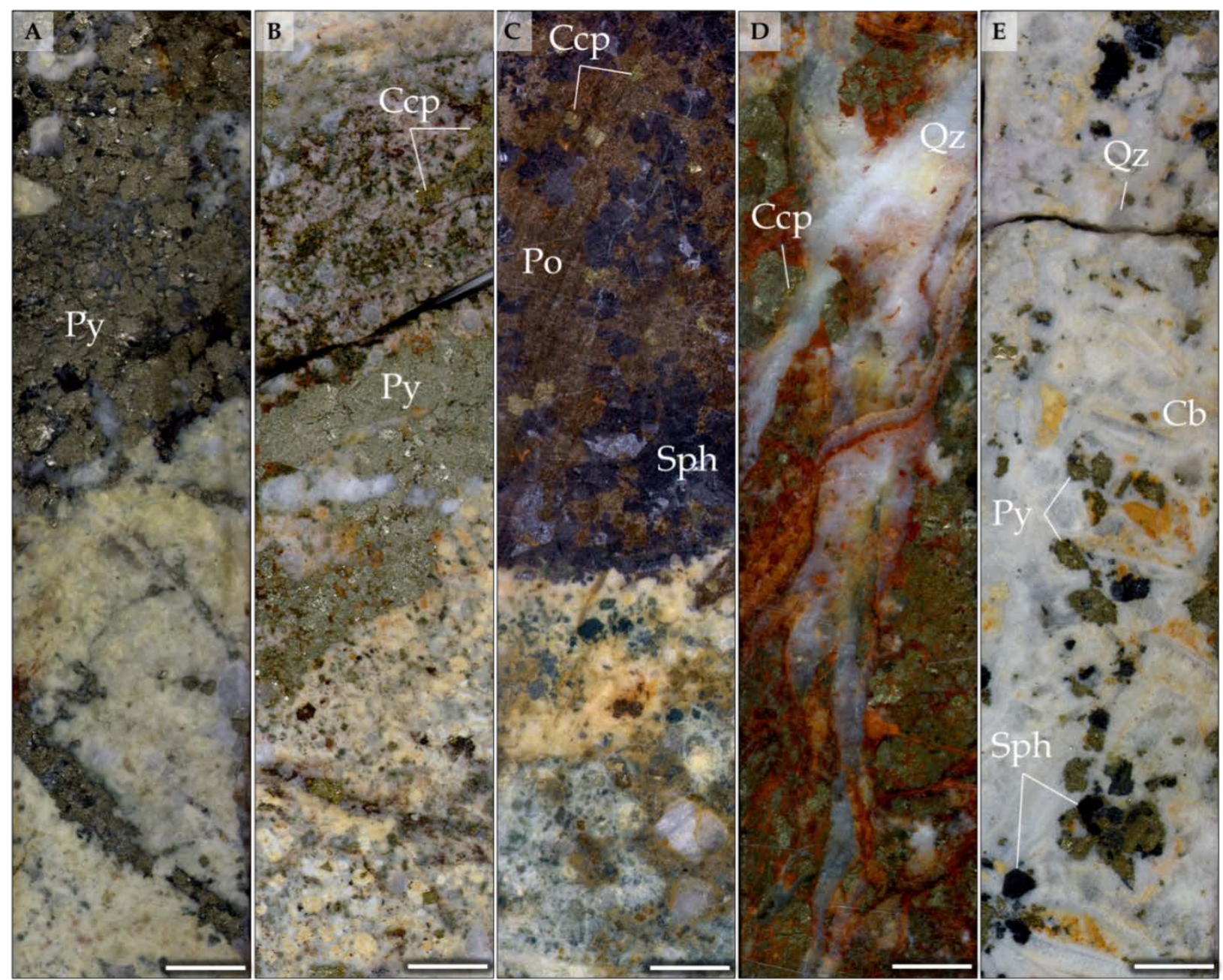

Figure 7. Marmato veins rocks types in hand specimen (Upper zone) A. Veins with massif pyrite and quartz in contact with porphyry dacite P1 which show a sericitic to weak argillic alteration halo in the wall-rock. B. Zoned vein with chalcopyrite in the center and pyrite in contact with the wall-rock with a sericitic to weak argillic alteration halo. C. Massif pyrrhotite and sphalerite (Marmatite) vein with minor chalcopyrite, wall-rock show two alteration zones, sericitic to weak argillic closer to the vein follow by a propylitic halo. D. Massif chalcopyrite with some oxides-hydroxides associated with banded quartz. E. Carbonate vein with some quartz associated with sphalerite (Marmatite) and pyrite. Veins thickness can be up to 2 meters. Py: Pyrite; Sph: Sphalerite (Marmatite); Ccp: Chalcopyrite; Po: Pyrrhotite; Qz: Quartz; Cb: Carbonate. Scale is 1cm 


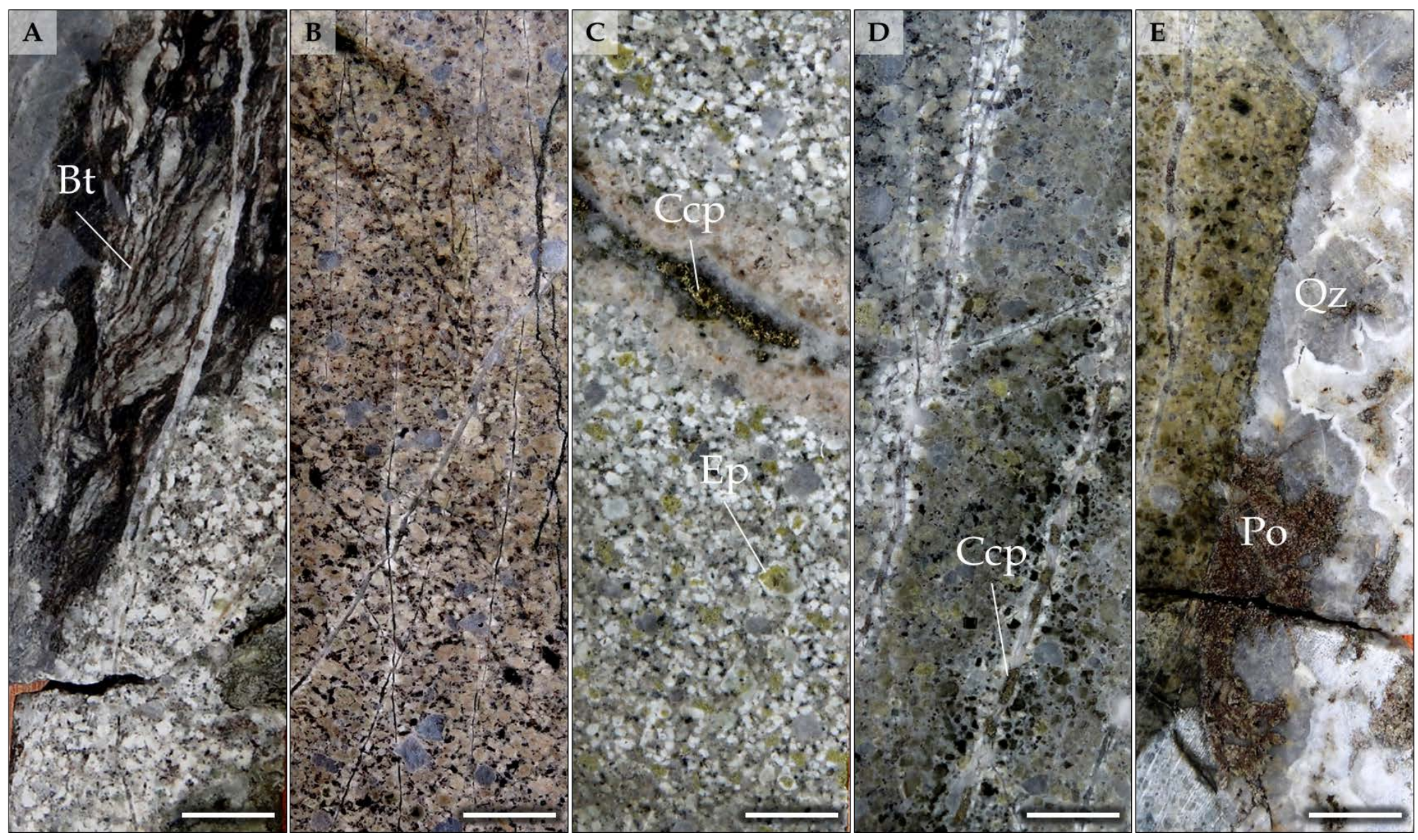

Figure 8. Marmato veinlets rocks types in hand specimen (Lower zone). Lower system show mostly veinlets array but veins are also display and thickness can be up to 10 centimeters A. Dacite porphyry P1 in contact with graphitic schist of the Arquía Complex, brownish color in both is generated by the presence of hydrothermal biotite (potassic alteration). B. Quartz with minor pyrrhotite veinlets in dacite porphyry P1 with potassic alteration. C-D. Chalcopyrite with quartz and minor pyrrhotite in a veinlet with a white feldspar halo and outer smectite-illite alteration crosscut dacite porphyry P1. E. Cockscomb and colloform banded quartz vein with pyrrhotite minor chalcopyrite crosscut dacite porphyry with propylitic and smectite-illite alteration halo.. Ccp: Chalcopyrite; Po: Pyrrhotite; Qz: Quartz; Bt: Hydrothermal biotite. Scale is 1cm. 


\subsection{Sampling and Analytical Methods}

Twenty six samples of least altered porphyry rocks were collected from drill cores of Gran Colombia Gold Corp. in the Marmato and Echandia Hills (mainly porphyry bodies P1-P5) and in the Aguas Claras zone (closely related porphyry bodies AP1-AP5) (Figure 3-Figure 5).

\subsubsection{Petrography}

Weakly altered samples of the different porphyry units of the Marmato gold deposit were analyzed for igneous petrography purposes. A total of 26 thin sections were used for point counting. The modal analyses were classified according to the QAP triangle for plutonic and silica-saturated rocks of (Le Maitre, 2002).

\subsubsection{Electron Probe Microanalyzer- EPMA}

A total of 93 EPMA analyses on ilmenites and magnetites crystals were carried out from the MACS intrusions at Brasilia University and National University of Colombia with a JEOL JXA-8500 electron microprobe and JEOL JXA-8230 superprobe, respectively, both possessing XRM area mapping and back-scattered electron imaging capabilities. The measurements were done with a primary $\mathrm{W}^{6+}$ beam source of approximately 20-85 nA at $20 \mathrm{KeV}$. The primary ion beam diameter was 1-5 $\mu \mathrm{m}$.

\subsubsection{Lithogeochemistry}

Lithogeochemical analyses were obtained from ACME Laboratories in Canada by combined ICP-ES and ICP-MS techniques, with multi acid digestion after lithium borate fusion for major and trace elements, except for base metals that were extracted by acqua regia. Lecco technique was used for total $S$ and $C$. These were the same from the petrographic samples, and were collected from least-altered zones close to mineralization but away from veins, and altered zones trying to assess the effects of alteration. The accuracy of the analyses (as determined from analyses of international standards and duplicates) is within 5 relative \% for major elements, and within 10 relative \% for minor and trace elements. For plotting purposes, all major oxide compositions have been normalized to a volatile-free basis.

\subsubsection{Geochronology}

$\mathrm{U} / \mathrm{Pb}$ analyses were carried out at the Brasilia University Isotope Geochronology Laboratory. Zircons crystals from ten weakly altered intrusive porphyry rocks were analyzed. The samples were crushed using both a jaw and agate crushers, and then sieved to obtain the desired size fraction $(125-300 \mu \mathrm{m})$. Zircon crystals were further concentrated using a pan and finally a Frantz magnetic separator was used to remove magnetic minerals 
from the heavy mineral fraction. Final purification of zircons was done by handpicking. The zircons were analyzed by LA-MC-ICP-MS following the methodology proposed by (Bühn et al., 2009). Analyses were performed using spot size of $30 \mu \mathrm{m}$ and laser induced fractionation of the ${ }^{206} \mathrm{~Pb} /{ }^{238} \mathrm{U}$ ratio was corrected using the linear regression method (Koesler et al., 2002).

$\mathrm{Ar} / \mathrm{Ar}$ analyses were realized at OSU Argon Geochronology Lab. Adularia crystals from one hydrothermal vein (Upper zone) and one veinlet (Lower zone) were analyzed by a Thermo Scientific ARGUS VI multi-collector mass spectrometer.

\subsubsection{Sr-Nd isotopes}

Sr-Nd isotope analyses for whole-rock samples were conducted in the Geochronological Laboratory at Universidade de Brasilia, Brazil. For Sr-Nd analyses applied in this study were the same as those described by (Gioia \& Pimentel, 2000), the samples were broken by hammer, crushed in a jaw crusher discarding rock chips with visible features of weathering/ hydrothermal alteration, washed in deionized water, leached for 25-30 minutes in warm $1 \mathrm{~N}$ distilled $\mathrm{HCl}$ in an ultrasonic bath, and ground to a fine powder using a WC shatter box.

Separation of Sm from Nd was accomplished by using cation exchange columns, after which obtained fractions were evaporated with two drops of $0.025 \mathrm{~N} \mathrm{H}_{3} \mathrm{PO}_{4}$. The residue was dissolved in $1 \mu \mathrm{l}$ of $5 \%$ distilled $\mathrm{HNO}_{3}$ and loaded onto a double Re filament assembly. The mass spectrometer used was a Finnigan MAT 262 with 7 collectors with analyses accomplished in static mode. Uncertainties for ${ }^{147} \mathrm{Sm} /{ }^{144} \mathrm{Nd}$ and ${ }^{143} \mathrm{Nd} /{ }^{144} \mathrm{Nd}$ ratios were better than $\pm 0.2 \%(2 \sigma)$ and $\pm 0.0045 \%(2 \sigma)$, respectively, based on analysis of BHVO-1 international rock standard. The ${ }^{143} \mathrm{Nd} /{ }^{144} \mathrm{Nd}$ ratio was normalized using ${ }^{146} \mathrm{Nd} /{ }^{144} \mathrm{Nd}=0.7219$ and the employed decay constant was $6.54 \times 10-12 \mathrm{y}-1$ (Lugmair \& Marti, 1978).

For Sr isotope analyses, the methodology employed consist of after acid digestion and separation in cation exchange columns, the Sr-bearing fractions were deposited along with $1 \mu \mathrm{l}$ of $\mathrm{H}_{3} \mathrm{PO}_{4}$ onto a Ta filament of a Finnigan MAT 262 mass spectrometer. Based on

analysis of the NBS987 international standard, ${ }^{87} \mathrm{Sr} /{ }^{86} \mathrm{Sr}$ ratio uncertainties were better than $\pm 0.0036 \%(2 \sigma)$. The Rb decay constant employed was that from (Nebel et al., 2011) with a value of $1.393 \times 10-11 \mathrm{y}-1$.

\subsection{Results}

\subsubsection{Petrography of porphyry intrusions and relative chronology of magmatic events}

The samples are comprises by two principal groups which present a different geographic location (Figure 3). The Marmato porphyry group comprises intrusions P1 to P5 while the 
Aguas Claras porphyry group covers intrusions AP1 to AP5 (Figure 9-Figure 10). The relative temporal evolution of the different bodies was defined in drill core by cross-cutting relationships (Figure 4-Figure 5). Textural and mineralogical characteristics are shown in (Table 1).

\subsubsection{Marmato porphyry group}

The Marmato porphyry group is located close around the Burro Hill and is represented by hornblende dacite-andesite sub-intrusive porphyry bodies (Figure 9-Figure 10). Hydrothermal alteration in the Marmato group is dominantly propylitic although moderate potassic have been found in the deeper zones of the deposit.

Dacitic intrusions are characterized by quartz, hornblende, biotite and zoned plagioclase phenocrysts in a fine grained quartz-plagioclase groundmass, nevertheless phenocrysts proportion and sizes are different from one body to other. Andesitic intrusions show the same petrographic characteristics except for the absence of quartz phenocrysts (Figure 9Figure 10). Intrusion P1 is the main porphyry body in the Marmato group and corresponds to a porphyry dacite intrusion with large $\beta$ quartz $(>7 \mathrm{~mm})$ phenocrysts intruded by intrusion P2 which corresponds to a porphyry dacite intrusion that exhibits fewer and smaller phenocrysts. Intrusion P3 forms porphyry andesite dike-like with plagioclase megacrysts $(>10 \mathrm{~mm})$ which cut intrusions P1 and P2. Intrusion P4 is a porphyry andesite intrusion which cut intrusions $\mathrm{P} 1, \mathrm{P} 2$ and $\mathrm{P} 3$, and is characterized by smaller plagioclase phenocrysts. Finally, Intrusion (P5), the youngest porphyry in the Marmato group represented by a porphyry dacite dike-like intrusion characterized by large quartz and elongate plagioclase phenocrysts which cut intrusion P1. Mineralization is hosted mainly by intrusions P1 to P4 while almost nonexistent in the intrusion P5.

\subsubsection{Aguas Claras porphyry group}

The Aguas Claras porphyry group is located $3 \mathrm{~km}$ to the southeast of the Marmato porphyry group and mostly comprises biotite-hornblende dacite sub-intrusions bodies and an inequigranular medium grained biotite micro-granodiorite (Figure 9-Figure 10).. The dominant alteration types are potassic with biotite and magnetite, moderate calc-sodic alteration with actinolite, and weak propylitic alteration.

Similar to the Marmato group, most of the Aguas Claras group intrusions are characterized by porphyritic texture with biotite, hornblende, quartz, and zoned plagioclase phenocrysts in a fine grained quartz-plagioclase groundmass, with variation in the proportion and size of phenocrysts from one body to other (Figure 9-Figure 10). The dike-like intrusion AP1 is hosted into the intrusion AP3, contact zone has only been intersected in a single drill hole, where AP1 show an inequigranular medium grained granodiorite composed of fresh plagioclase, quartz, biotite and lesser K-feldspar. Intrusion AP2 is a porphyry dacite with 
weak flow texture and phenocrysts of quartz $(<2 \mathrm{~mm})$. Intrusion AP3 correspond to a porphyry dacite with characteristic large quartz $(<10 \mathrm{~mm})$ phenocrysts. Intrusion AP4 is a porphyry dacite formed by abundant quartz and plagioclase phenocrysts $(<4 \mathrm{~mm})$ with minor hornblende and biotite $(<2 \mathrm{~mm})$. Finally, intrusion AP5 is a porphyry dacite characterized by homogeneous sized $(<2 \mathrm{~mm})$ quartz, plagioclase, hornblende and lesser biotite phenocrysts. 

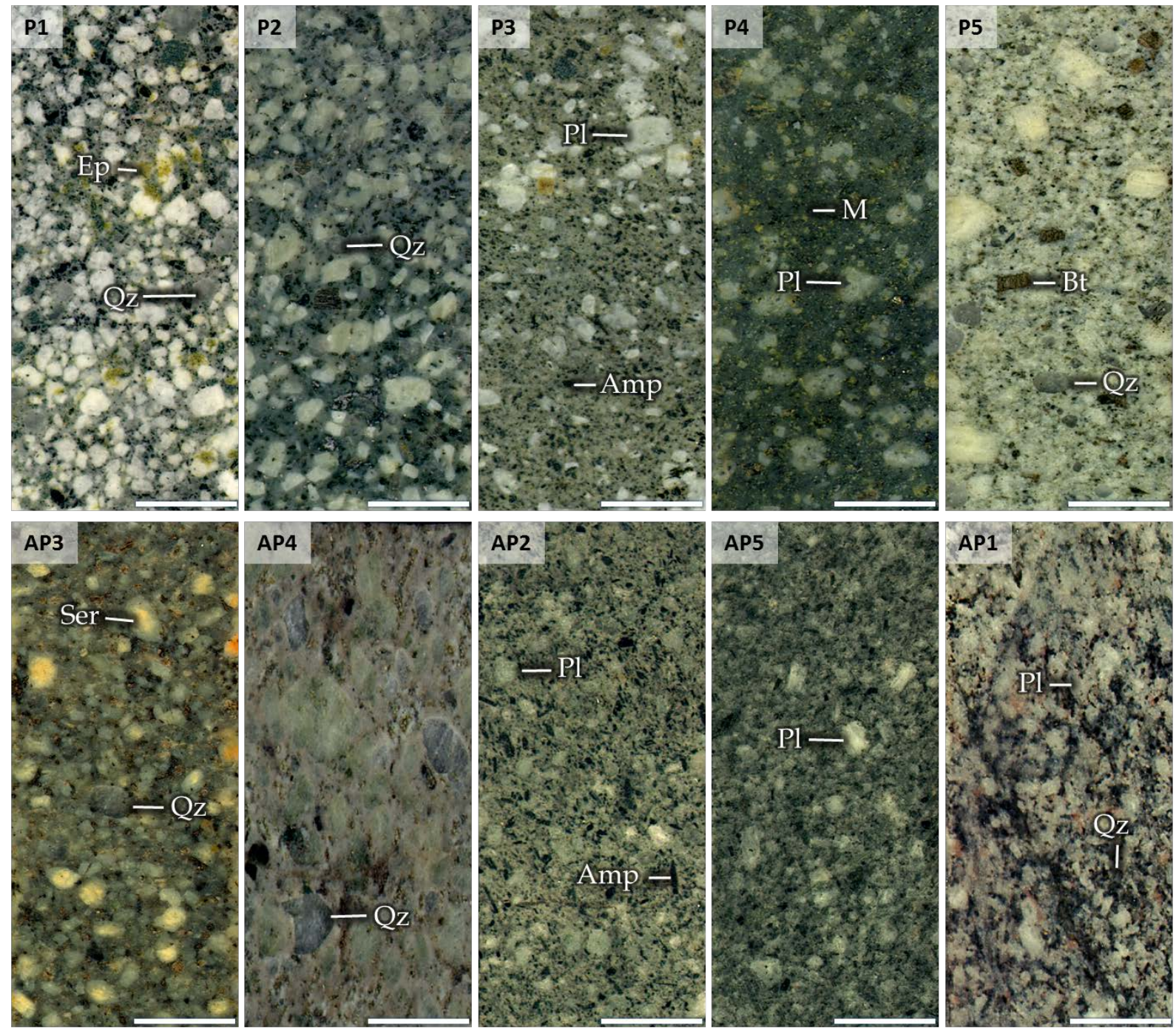

Figure 9. Marmato (P1 to P5) and Aguas Claras (AP1 to Ap5) rocks in hand sample. Intrusions are characterized by variable proportion and sizes of phenocrysts from one body to other, where phenocrysts are quartz (Qz), amphibole (Amp), biotite (Bt) and plagioclase ( $\mathrm{Pl})$ phenocrysts in a matrix $(\mathrm{M})$. Scale $1 \mathrm{~cm}$. Ep: Epidote; Ser: Sericite. 


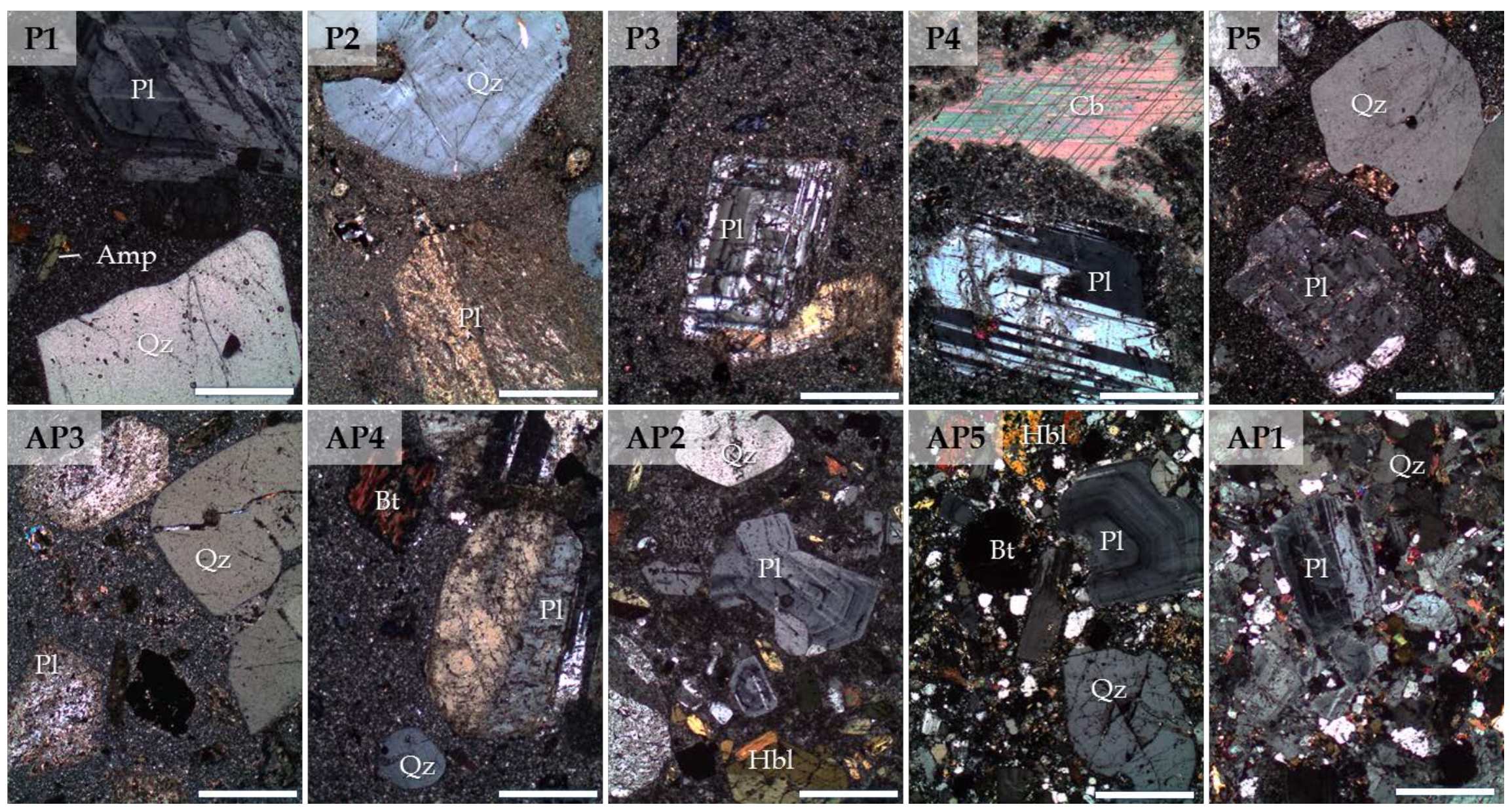

Figure 10 Marmato (P1 to P5) and Aguas Claras (AP1 to Ap5) rocks in thin sections. Dacites are characterized by quartz (Qz), hornblende (Hbl), biotite (Bt) and zoned plagioclase (Pl) phenocrysts in a fine grained quartz-plagioclase groundmass. Phenocrysts proportion and sizes are different from one body to other. Andesitic intrusions show the same

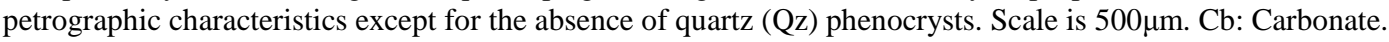


Additionally, anhydrite occurs along with veins and cracks with quartz, biotite, magnetite, and sulfides in intrusion AP1, which suggest that anhydrite crystallized together with hydrothermal minerals (Figure 11F).

\subsubsection{Oxide Petrography}

\subsubsection{Marmato porphyry group}

Altered ilmenite and idiomorphic ilmenite pseudomorphs are widely distributed throughout the samples from Marmato intrusions. Some magnetite crystals occur in intrusions P1 and P3, but magnetite or magnetite pseudomorphs are not recognized in the other intrusions. P5 intrusion lacks ilmenite and magnetite crystals or their pseudomorps at least in the analyzed section probably because of alteration (Figure 11) (Table 1). Sulfides drops are not present in oxides. The above suggest that magnetite and ilmenite were derived from a magmatic origin. The primary hydrothermal mineral assemblage is pyrrhotite-chalcopyrite-pyrite in veinlets commonly accompanied by bismuth (Lower zone) (Figure 12) (Table 1).

\subsubsection{Aguas Claras porphyry group}

Magnetite has been widely recognized in intrusion AP1 without ilmenite or ilmenite pseudomorphs in the sample, while intrusions AP2 and AP5 contain idiomorphic ilmenite and magnetite, and AP4 has idiomorphic ilmenite without magnetite. Intrusion AP3 has neither magnetite nor ilmenite crystals nor pseudomorps in the analyzed section probably because of alteration. Magnetite mostly shows well defined borders, but subeuhedral forms have been also recognized, it occurs in veinlets and disseminated. In addition, sulfides drops (pyrite-chalcopyrite) are present in magnetite crystals but not in ilmenite. Occasionally irregular magnetite is observed around altered ilmenite (Figure 11) (Table 1). Textural observations suggest that ilmenite is magmatic while at least most of the magnetite is hydrothermal but magmatic magnetite could be also present and might have been precipitated from the magma after or at the same time with ilmenite crystallization. The primary hydrothermal mineral assemblage is magnetite-chalcopyrite-pyrite in veinlets (Figure 12) (Table 1). 


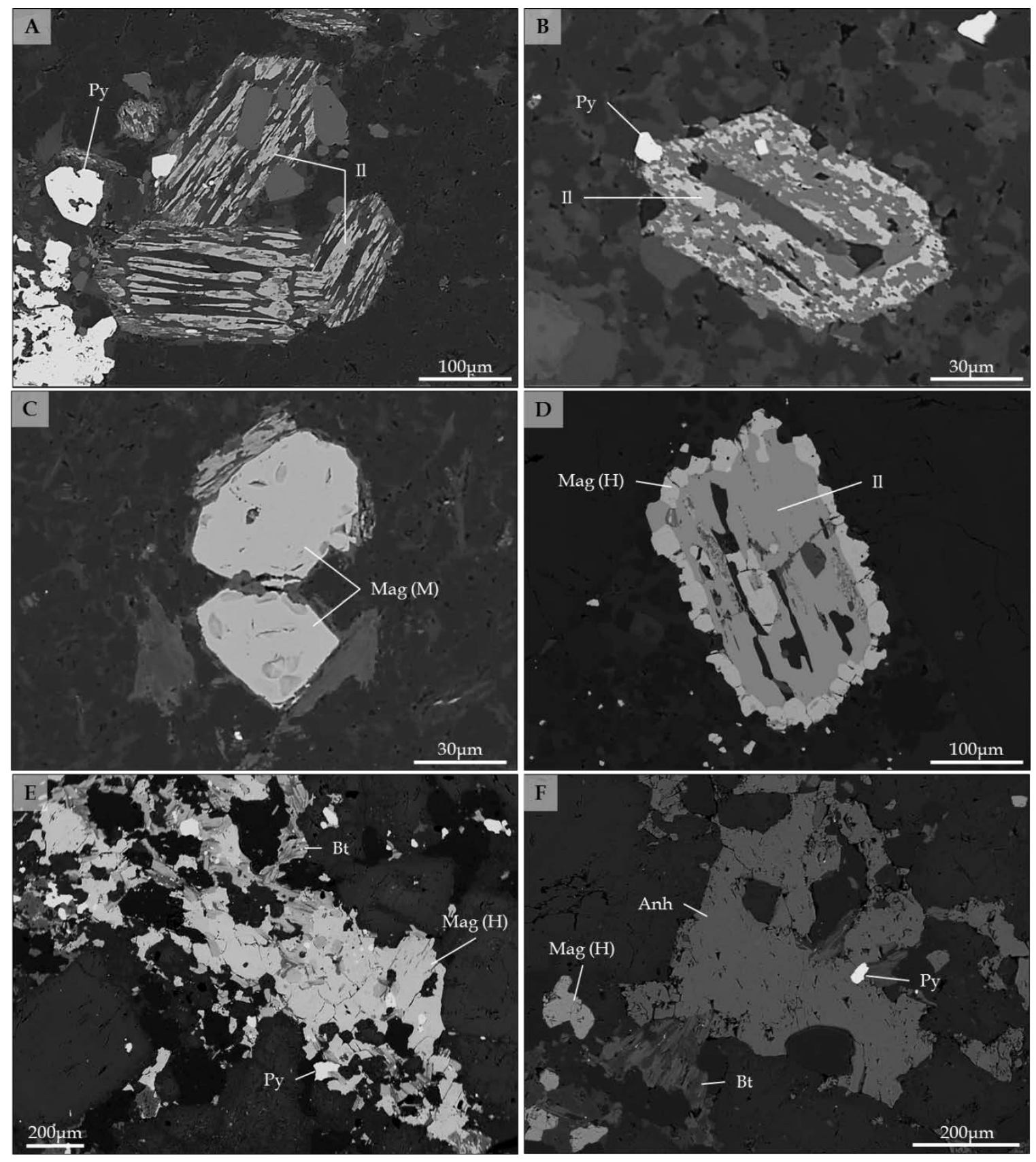

Figure 11 EPMA images from MACS: A. Mn-Ilmenite cluster in porphyry andesite (P4); B. Mn-ilmenite crystal in porphyry dacite (P1); C. Magmatic magnetite crystal in porphyry andesite (P3); D. Mn-ilmenite crystal surrounded by hydrothermal magnetite. E. Veinlet with hydrothermal magnetite, biotite and pyrite; and F. Hydrothermal anhydrite associated with pyrite, magnetite and biotite. Anh: Anydrite, Bt: Biotite, Py: Pyrite, Il: Ilmenite, Mt: Magnetite, M: magmatic, H: Hydrothermal. 
Table 1 Textural and mineralogical characteristics of MACS intrusions. Bt: Biotite phenocrysts; Hb: Hornblende phenocrysts; Il: Ilmenite; Mag: Magnetite; Po: Pyrrhotite; Ccp: Chalcopyrite; and Py: Pyrite.

\section{Aguas Claras Porphyry Group}

\begin{tabular}{|c|c|c|c|}
\hline Intrusion & Rock Name & Alteration Type & $\begin{array}{l}\text { Magmatic oxides } \\
\text { ocurrences }\end{array}$ \\
\hline AP1 & Microgranodiorite (Bt) & Moderate Potassic & Mag? \\
\hline AP2 & Porphyry Dacite & $\begin{array}{l}\text { Dominant Strong Potassic, subordinate } \\
\text { weak proplitic }\end{array}$ & II, Mag? \\
\hline AP3 & Porphyry Dacite $(\mathrm{Bt}+\mathrm{Hb})$ & Weak Propylitic & \\
\hline AP4 & Porphyry Dacite (Bt) & Calc-sodic & II \\
\hline AP4 & Porphyry Dacite (Bt) & $\begin{array}{l}\text { Dominant Moderate Potassic, subordinate } \\
\text { weak propylitic }\end{array}$ & \\
\hline \multirow[t]{2}{*}{ AP5 } & Porphyry Dacite $(\mathrm{Bt}+\mathrm{Hb})$ & Weak propylitic & II, Mag? \\
\hline & & Marmato Porphyry Group & \\
\hline P1 & Porphyry Dacite $(\mathrm{Hb}+\mathrm{Bt})$ & $\begin{array}{l}\text { Moderate propylitic, weak potassic and } \\
\text { argillic }\end{array}$ & II, Mag \\
\hline $\mathrm{P} 2$ & Porphyry Dacite (Hb) & Strong propylitic & ॥ \\
\hline P3 & Porphyry Andesite (Hb) & Moderate Propylitic & II, Mag \\
\hline P4 & Porphyry Andesite (Hb) & Moderate Propylitic & II \\
\hline P5 & Porphyry Dacite (Hb) & Weak Propylitic & \\
\hline
\end{tabular}



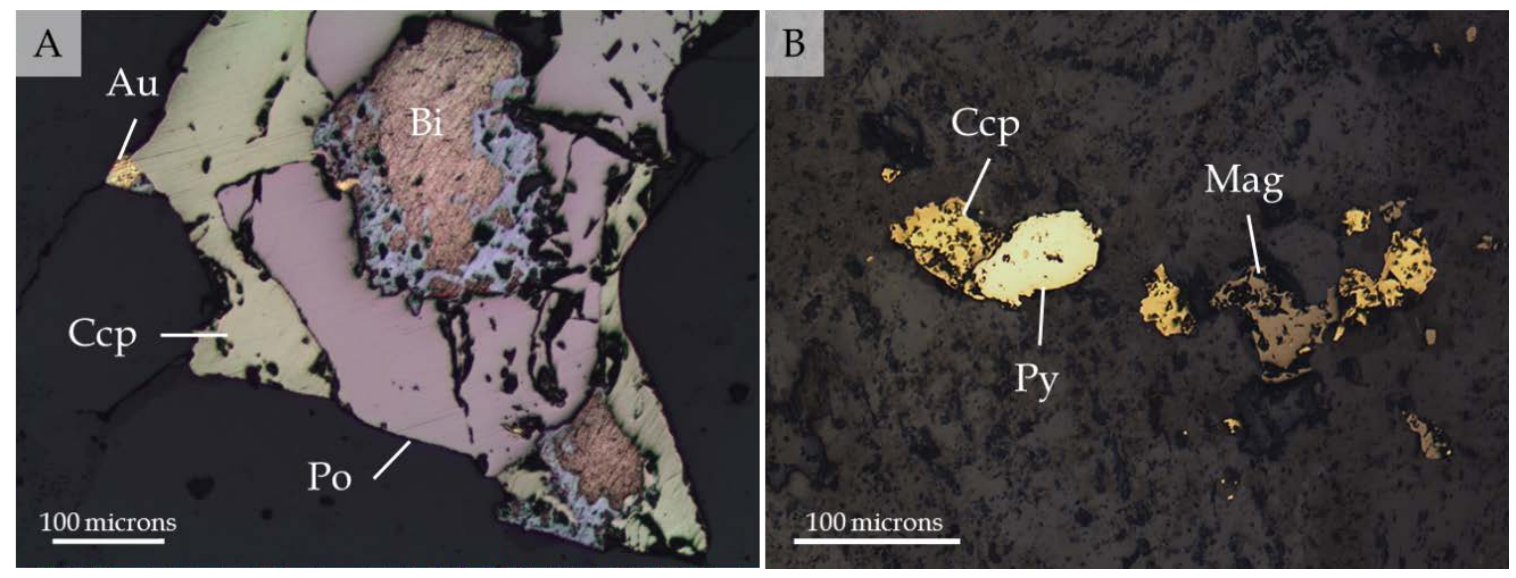

Figure 12 A. Primary hydrothermal mineral assemblages in the Marmato deposit (Lower zone) composed by pyrrhotite (Po), chalcopyrite (Ccp), pyrite (Py) in veinlets accompanied by bismuth (Bi). B. Magnetite (Mag), chalcopyrite (Ccp) and pyrite (Py) in veinlets characterizing the hydrothermal mineral assemblage in the Aguas Claras deposit.

\subsubsection{Lithogeochemistry}

26 samples from the MACS porphyry bodies were analyzed for whole-rock geochemistry. Because of the widespread hydrothermal alteration, we selected samples with up (LOI $<5$ weight \%), because samples with higher LOI (2.2 to 4.9 weight \%) show similar patterns with samples with lower LOI ( $<2.2$ weight $\%$ ). Samples with (LOI $>5$ weight) were discard because they start to show anomaly geochemistry patterns and values. Adittionally, because alteration can modify the major element chemistry (especially for the alkali and alkali earth elements), the most altered samples have been avoided on the geochemical diagrams to allow a better petrogenetic interpretation. Most samples exhibit weak propylitic alteration related. A few samples from the MACS show weak potassic and calc-sodic alterations, and some others show sericitic and intermediate argillic alteration related to gold mineralization. Adularia is also present in one sample infilling cavities together with quartz, and is directly related to gold mineralization. The range of geochemical data for Miocene igneous rocks of the La Colosa porphyry Au deposit (Gil-Rodriguez, 2010), and the Buriticá epithermal Au deposit (Lesage et al., 2013) are also plotted for comparison.

When plotted on a total alkali-silica classification diagram (Le Bas et al., 1986), the MACS mostly plot in the andesite and dacite fields (Figure 13). One sample of the Marmato porphyry andesite (P3) straddles the basaltic trachydacite field, while weakly potassic altered dacite (P2) straddles the trachyandesite field (Figure 13). Hydrothermal alterations slightly increased or decreased the $\mathrm{K}_{2} \mathrm{O}, \mathrm{CaO}$ and $\mathrm{Na}_{2} \mathrm{O}$ content of some porphyry samples, but do not appear to have significantly affected the $\mathrm{SiO}_{2}$ content. Samples from MACS are mainly characterized by $\mathrm{SiO}_{2}$ between 60.8-66.1 weight\%, high $\mathrm{Al}_{2} \mathrm{O}_{3}$ values (15.5-16.5 weight\%), moderate $\mathrm{Na}_{2} \mathrm{O}$ (3-5.6 weight\%), low $\mathrm{K}_{2} \mathrm{O}$ (0.9-3.8 weight\%), low $\mathrm{MgO}$ (0.9-2.5 
weight\%) and a low magnesium number (Mg\#) (0.32 and 0.47). On the other hand the trace elements shows a high Sr content (466-1140 ppm) and low Y (4.9-17.2 ppm) (Table 2).

Harker diagrams plotted as a function of $\mathrm{SiO}_{2}$ show that the MACS does not reveal any clear fractionation trends, however there is a slight decrease of $\mathrm{MgO}, \mathrm{FeO}$ total, $\mathrm{TiO}, \mathrm{MnO}$ and $\mathrm{Y}$ while $\mathrm{Al}_{2} \mathrm{O}_{3}$ content apparently do not change with silica increase (Figure 14). The Sr does not show any clear trend.

Table 2. Parameters and characteristic values for Adakites rocks compared with MACS. Values from (Richards, 2007 and Caceres, 2010 after Kay, 1978; Defant and Drummond, 1990; Peacock et al., 1994; Rollinson and Martin, 2005; Martin et al., 2005). (Dy/Yb) $)_{\mathrm{N}}$ value from Kelemen et al., 2014 for magnesian andesites. Actual subducted oceanic crust age related to MACS from (Muller et al., 2008).

$\begin{array}{cccc}\text { Parameter } & \begin{array}{c}\text { Characteristic } \\ \text { value }\end{array} & \text { Marmato group } & \text { Aguas Claras group } \\ \mathrm{SiO}_{2} & \geq 56 \mathrm{wt} \% & 61.8-66.1 & 60.8-65.6 \\ \mathrm{Al}_{2} \mathrm{O}_{3} & \geq 15 \mathrm{wt} \% & 15.5-16.3 & 15.6-16.5 \\ \mathrm{MgO} & <\sim 3 \mathrm{wt} \% & 0.8-2.0 & 1.2-2.5 \\ \mathrm{Mg} \# & \sim 0.5 & 0.32-0.46 & 0.41-0.47 \\ \mathrm{Na}_{2} \mathrm{O} & \geq \sim 3 \mathrm{wt} \% & 3.0-5.6 & 3.5-5.2 \\ \mathrm{~K}_{2} \mathrm{O} & \leq 3 \mathrm{wt} \% & 0.9-3 & 1.8-2.8 \\ \mathrm{~K}_{2} \mathrm{O} / \mathrm{Na}{ }_{2} \mathrm{O} & \sim 0.42 & 0.16-1.26 & 0.52-0.68 \\ \mathrm{Rb} & \leq 65 \mathrm{ppm} & 30.6-72.6(\mathrm{Most}<65) & 39-62 \\ \mathrm{Sr} & \geq \sim 300 \mathrm{ppm} & 466-1140 & 843-1045 \\ \mathrm{Y} & \leq \sim 10 \mathrm{ppm} & 4.9-17.2 & 8.7-17 \\ \mathrm{Yb} & \leq \sim 1 \mathrm{ppm} & 0.53-1.86 & 0.78-1.89 \\ \mathrm{Ni} & \geq 20 \mathrm{ppm} & 1.1-7 & 1.7-51.8(\mathrm{Most}<20) \\ \mathrm{Cr} & \geq 30 \mathrm{ppm} & 14-27.4 & 20.5-68.4(\mathrm{Most}<30) \\ \mathrm{Sr} / \mathrm{Y} & \geq \sim 20 & >55 & >55 \\ \mathrm{La} / \mathrm{Yb} & \geq \sim 20 & 11.8-53.8(\mathrm{Most}<20) & 13.4-20.2 \\ (\mathrm{Dy} / \mathrm{Yb})_{\mathrm{N}} & >1.5 & 1-1.55 & 1.21-1.43 \\ { }^{87} \mathrm{Sr} /{ }^{86} \mathrm{Sr} & \leq 0.7045 & \leq 0.7045 & \leq 0.7045 \\ \mathrm{Subducted} \mathrm{Oceanic} & \leq 25 \mathrm{~m} . \mathrm{y} . & <25 \mathrm{~m} . \mathrm{y} . & <25 \mathrm{~m} . \mathrm{y} . \\ \mathrm{Crust} \mathrm{Age} & & & \end{array}$




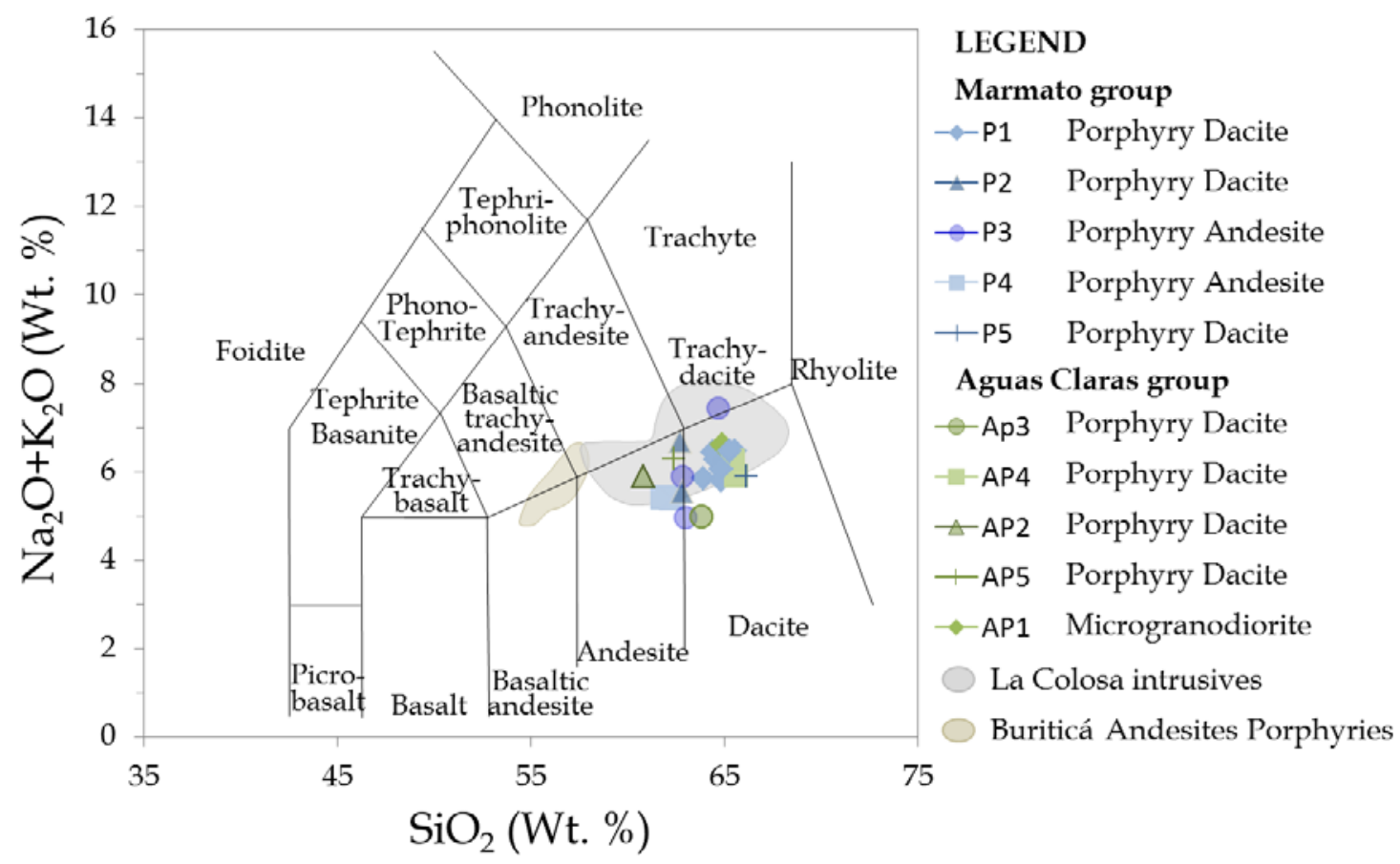

Figure 13 Total alkali-silica classification diagram from LeBas et al., (1986) for MACS rocks.

The MACS samples mostly plot between the calk-alkaline and high-K calk-alkaline fields (Peccerillo and Taylor, 1976) (Figure 14). Samples from the Buriticá deposit analyzed by Lesage et al. (2013), which were also weakly altered (propylitic, adularia-sericite and potassic), are more mafic and have slightly higher $\mathrm{K}_{2} \mathrm{O}$ contents lying on high-K calkalkaline series,. On the other hand samples from La Colosa deposit analyzed by GilRodriguez (2010), which were mostly weakly altered (potassic, intermediate argillic, sericite and propylitic), lie narrowly on the same trend as the Marmato andesite-dacite porphyries.

Trace element data are illustrated on normalized multi-element diagrams using normalization values from (Sun and McDonough, 1989) in Figure 15-Figure 16. The MACS is enriched in LREE with flat HREE profiles, showing general similar patterns, nevertheless three slightly different trends are distinguishable among them mainly by different MREE and HREE enrichment: 1) Intrusions P1, P2, P3, AP1, AP3 and AP4 which present values around 4-7 and 1.3-2.9 for MREE-HREE in the chondrite-normalized and the primitive mantle-normalized REE diagrams, respectively. 2) Intrusions P4, AP2 and AP5 which show MREE-HREE values around 10 and 3-4 in the chondrite-normalized and primitive mantle-normalized REE diagrams, respectively, and; 3) Intrusion P5 which displays MREE-HREE values around 2-3 and 0.8-1.1 in the chondrite-normalized and the primitive mantle-normalized REE diagrams. Although values for MREE-HREE in patterns 
1 and 3 are slightly different their show a parallel behavior, contrary to pattern 2 which show a clear no parallel trend with respect to patterns 1 and 3 .
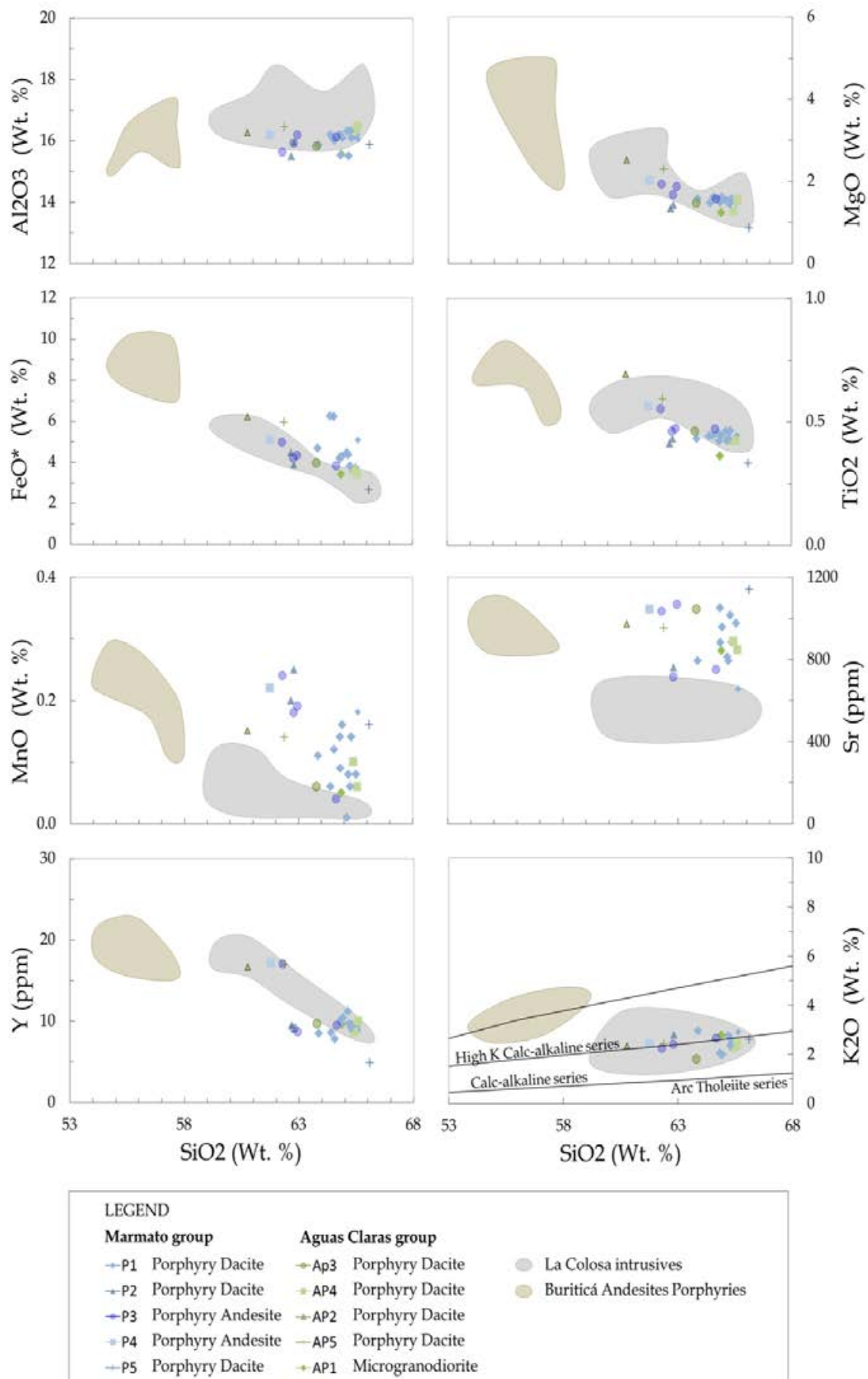

Figure 14 Harker diagrams for Marmato and Aguas Claras groups. La Colosa and Buritica for comparation. 


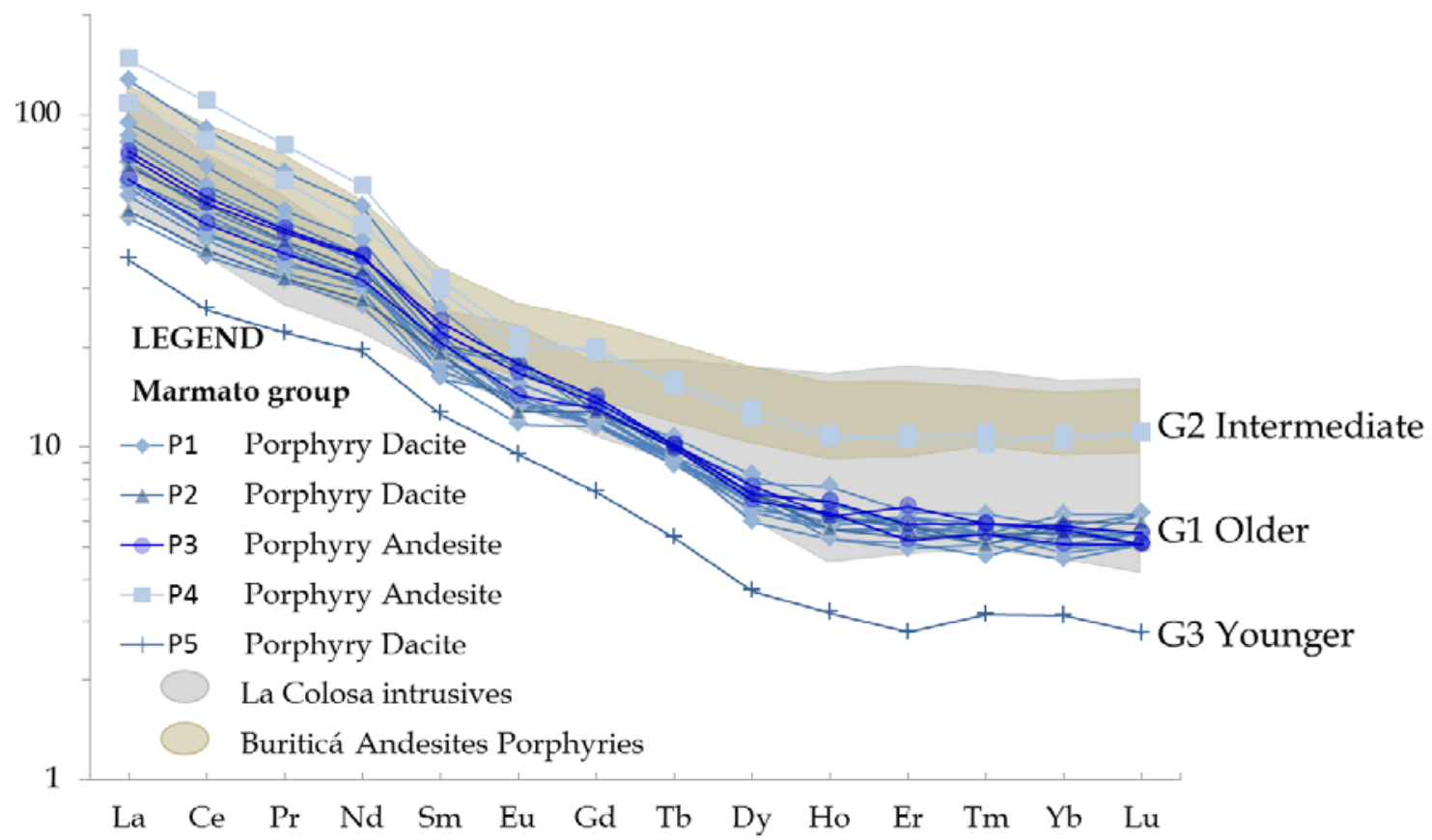

Figure 15 C1 normalized normalized REE diagram for Marmato group. G1: Group 1 (Older Intrusions P1, P2 and P3); G2: Group 2 (Intermediate intrusion P4); G3: Group 3 (Younger intrusion P5).

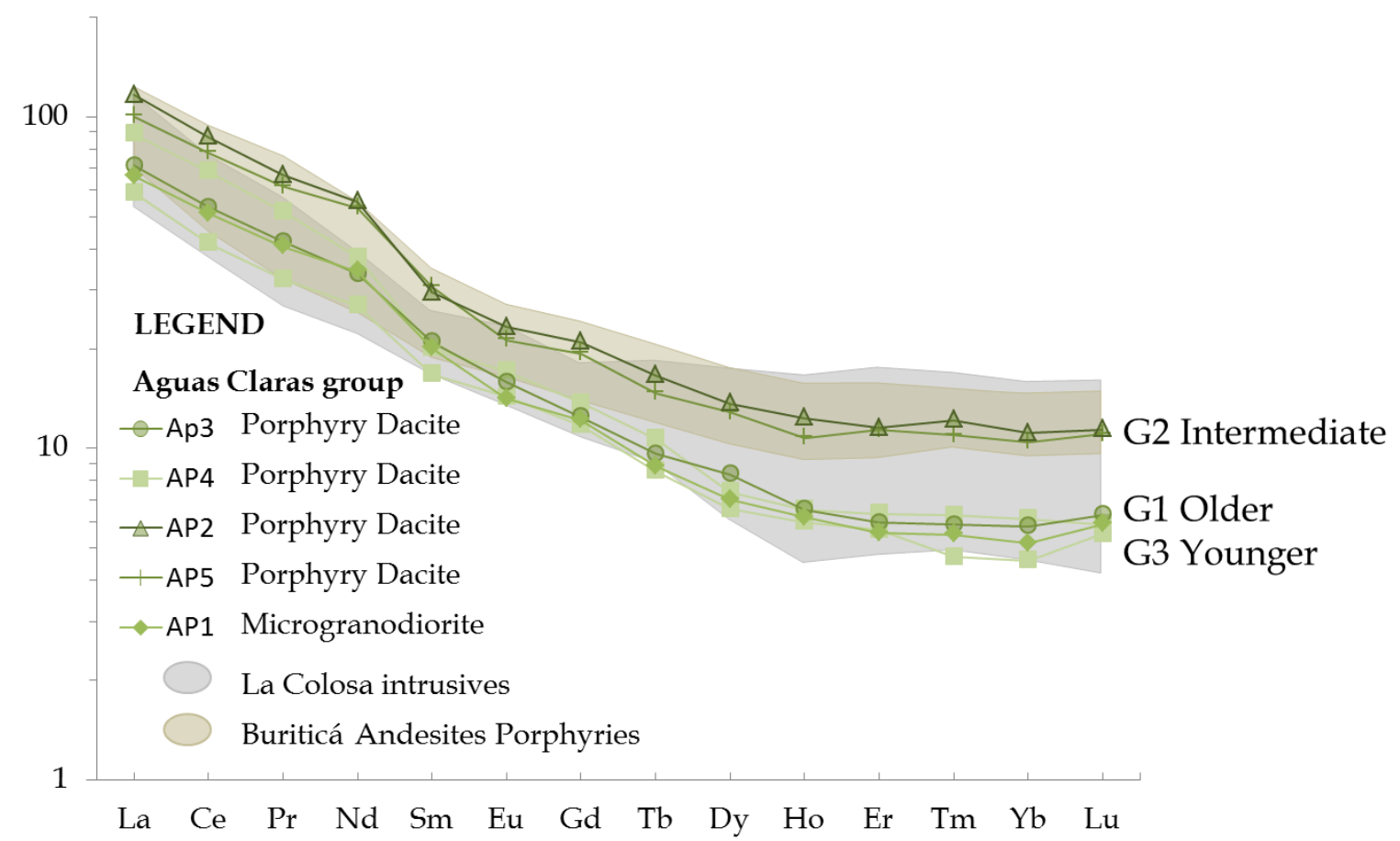

Figure 16 C1 normalized REE diagram for Aguas Claras group. G1: Group 1 (Older Intrusions AP3, AP4); G2: Group 2 (Intermediate intrusions AP2, AP5); G3: Group 3 (Younger intrusion AP1). 
Additionally, any element enrichment distinguish samples from moderately altered (propylitic, potassic, sericite altered, and adularia in cavities) and theses with weakly altered (propylitic) suggesting that alteration has not had a significant effect on fluid-mobile trace element concentrations, including rare earth elements (REEs) Figure 15-Figure 16. Marmato and Aguas Claras $\mathrm{Eu}_{\mathrm{N}} / \mathrm{Eu}^{*}$ anomalies (0.75-1.1) are consistent with samples from Buritica and La Colosa. Samples with flat to slightly negative $\mathrm{Eu}_{\mathrm{N}} / \mathrm{Eu}^{*}$ anomalies of 0.6-1 (Figure 17), suggest two possible process: 1) lack of plagioclase fractionation from primitive magmas, 2) high magmatic water contents or a high magmatic oxidation state which would either suppress plagioclase fractionation or cause $\mathrm{Eu}$ be present in the trivalent state in the melt, which does not partitioned into plagioclase (Frey et al., 1978; Hanson, 1980; Sisson and Grove, 1993), the last consistent with the presence of plagioclase phenocrysts in samples from MACS. Samples with a slightly positive $\mathrm{Eu}_{\mathrm{N}} / \mathrm{Eu}^{*}$ anomalies of $>1$ (Figure 17), indicate slightly or nor plagioclase accumulation in the rock (Green and Pearson, 1985). These are consistent with Eu values for samples from Buritica and La Colosa.

In a plot of $\mathrm{Sr} / \mathrm{Y}$ versus $\mathrm{Y}$, samples from the MACS are located in the field of adakite or adakite-like rocks over the normal arc rocks, but most fall below the adakitic or adakite-like field in a plot of $\mathrm{La} / \mathrm{Yb}$ versus $\mathrm{Yb}$ (Figure 17). All samples show weak enrichment of MREE relative to $\operatorname{HREE}\left([\mathrm{Dy} / \mathrm{Yb}]_{\mathrm{N}}=1.04-1.55\right)$ (Figure 17), suggesting both no significant involvement of garnet (Kelemen et al., 2014), and hornblende control on MREE-HREE abundances, consistent with the presence of hornblende phenocrysts in most samples from MACS. 

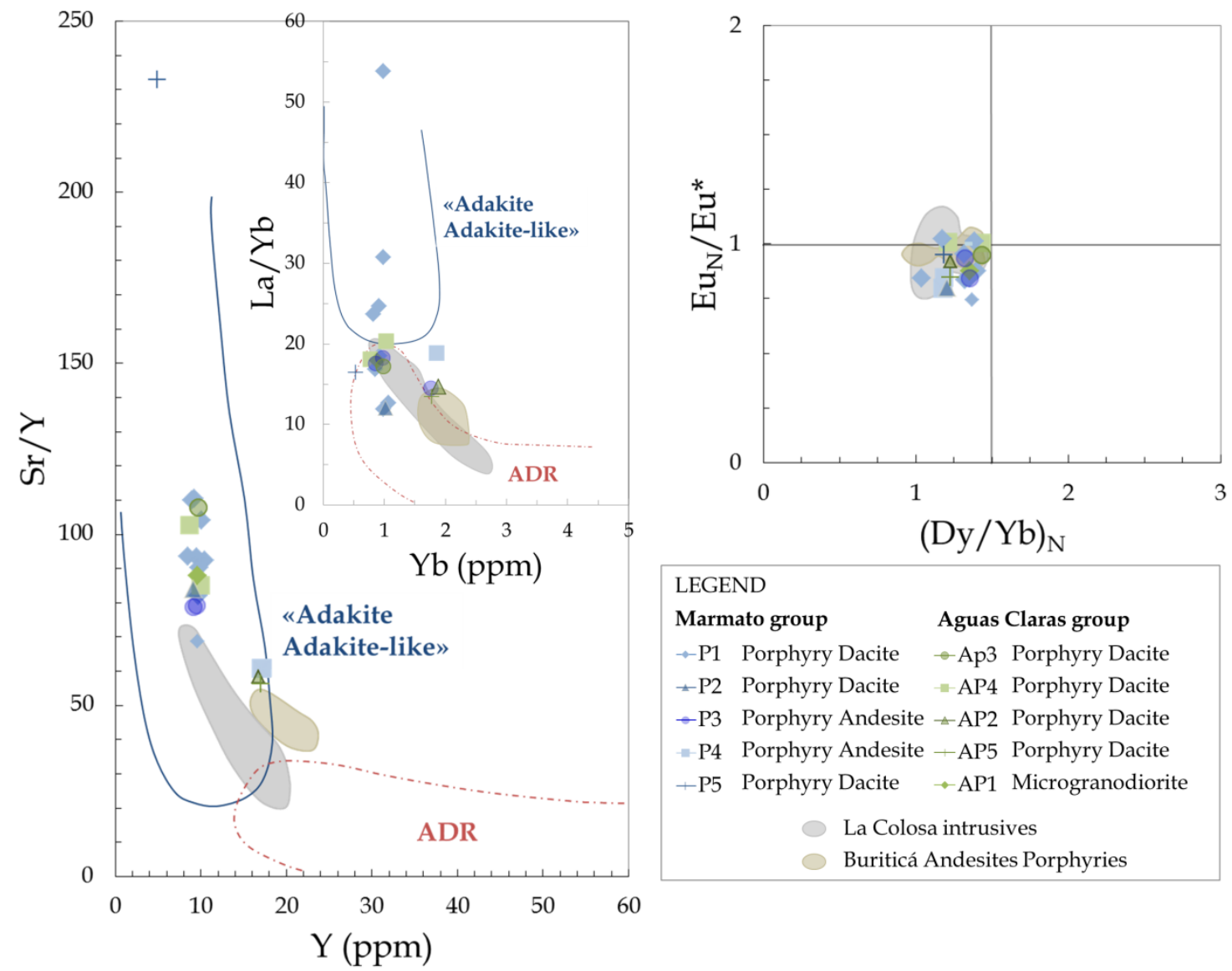

Figure $17 \mathrm{Sr} / \mathrm{Y}$ vs Y, La/Yb vs Yb modified from (Castillo, 2012 after Drummond and Defant, 1990) and Eu $\mathrm{Eu}_{\mathrm{N}} / \mathrm{Eu}^{*} \mathrm{vs}$ $(\mathrm{Dy} / \mathrm{Yb})_{\mathrm{N}}$ modified from Kelemen et al., 2014,diagrams for MACS. Note the high Sr/Y “Adakite Like”, but low La/Yb, $\mathrm{Eu}_{\mathrm{N}} / \mathrm{Eu}^{*}<1$, and the $(\mathrm{Dy} / \mathrm{Yb})_{\mathrm{N}}<1.5$ ratios for MACS. ADR: Normal arc andesite, dacite and rhyolite lavas.

On an extended trace element diagram (Figure 18-Figure 19), samples from MACS show patterns consistent with an evolved arc source. LILE enrichments and strong negative anomalies for $\mathrm{Nb}$, Ta, and $\mathrm{Ti}$ are mostly characteristics of subduction zone magmatism. Other incompatible elements are also enriched (Figure 18-Figure 19). Lead and antimony, although commonly abundant in subduction related rocks, are present in unusually high concentrations in the MACS, independently of whether the samples are weakly or moderately altered, but nevertheless likely reflect mobilization in hydrothermal fluids, as evidenced by the abundance of galena in mineralized veins. The Marmato dacite-andesite porphyries samples are very similar to those from the La Colosa and least altered Buriticá deposits in trace element composition. 


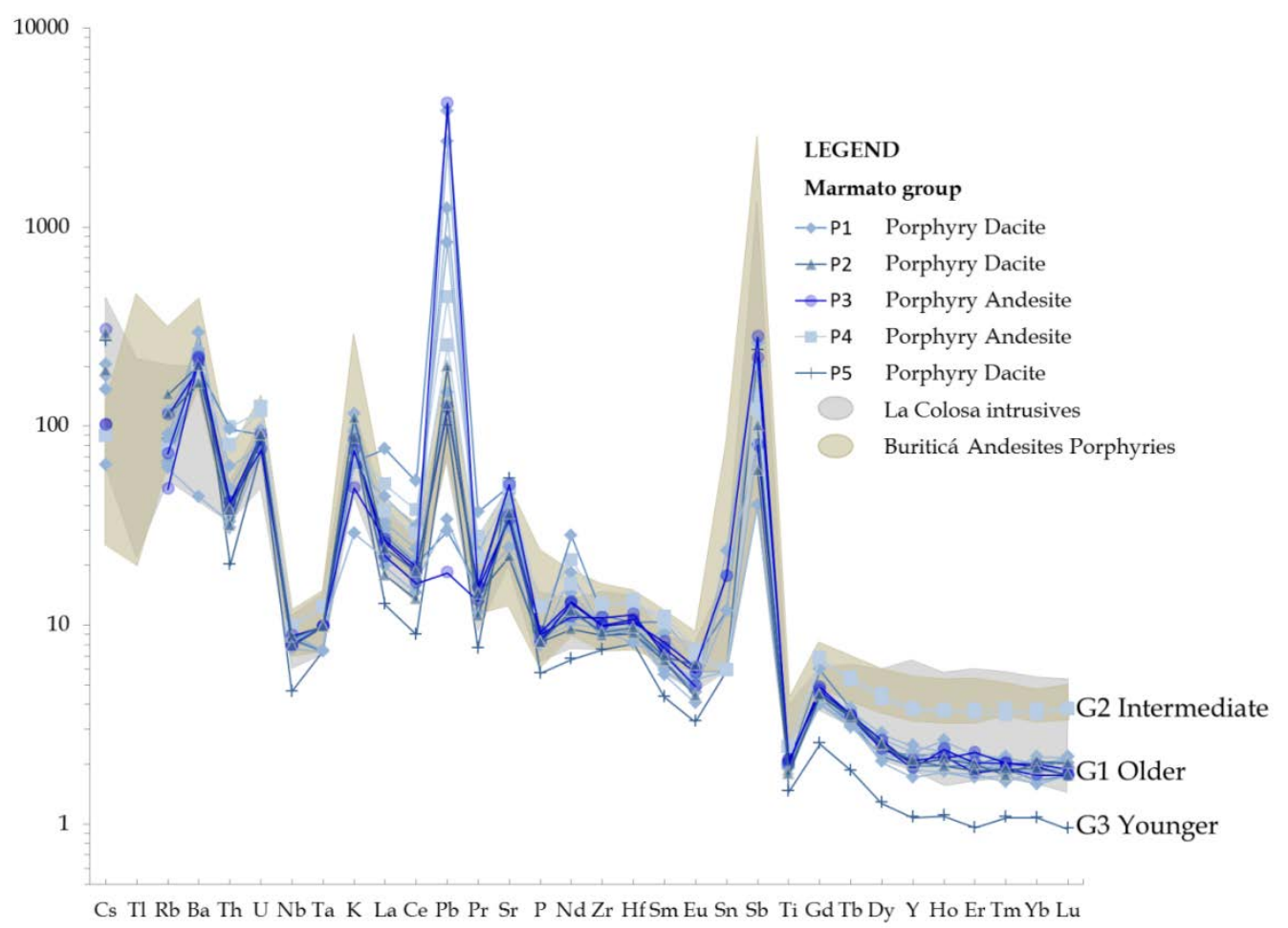

Figure 18 Primordial mantle normalized trace element patterns for the Marmato group. G1: Group 1 (Older Intrusions P1, P2 and P3); G2: Group 2 (Intermediate intrusion P4); G3: Group 3 (Younger intrusion P5). 


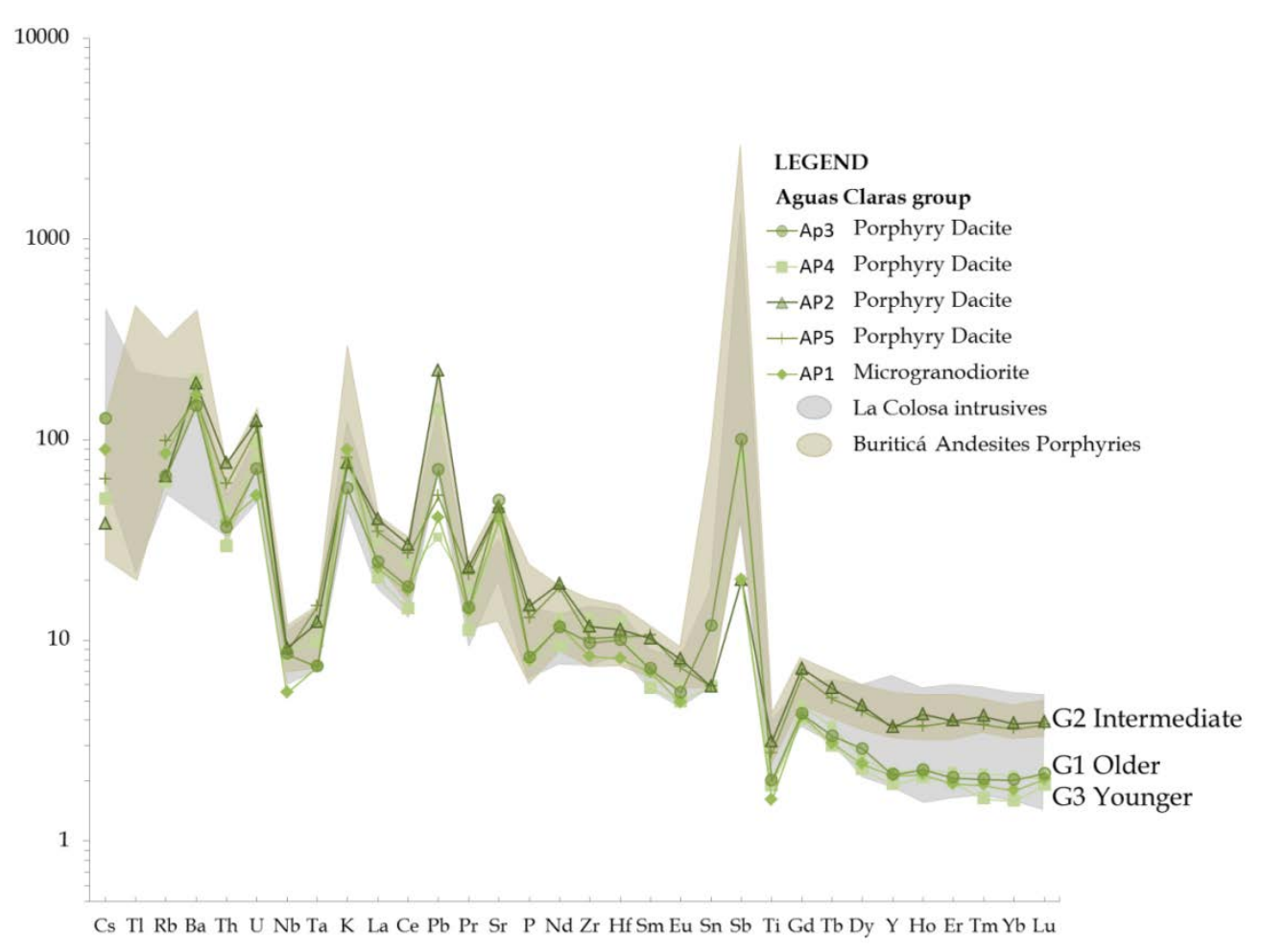

Figure 19 Primordial mantle normalized trace element patterns for Aguas Claras group. G1: Group 1 (Older Intrusions AP3, AP4); G2: Group 2 (Intermediate intrusions AP2, AP5); G3: Group 3 (Younger intrusion AP1).

\subsubsection{Oxides chemistry}

EPMA analyses of 59 ilmenites crystals and 34 magnetites crystals from samples of the MACS intrusions were carried out. Unfortunately, oxides from intrusions P2, P5 and AP3 were too much altered and no data is available about these. Representative oxides images and analyses are in (Figure 11) and (Table 3). Complete oxides analyses are in (Annex 1Annex 3) As mentioned above, ilmenite is the dominant oxide mineral in the Marmato group, EPMA analyses show that ilmenites are Mn bearing (around 14.7wt\% in andesites and around 6.2wt\% in dacites), calculated structural formula for andesites (P3 and P4) is $\left(\mathrm{Mn}_{0.3}\right) \mathrm{Fe}_{0.7} \mathrm{TiO}_{3}$ while for dacite $\mathrm{P} 1$ is $\left(\mathrm{Mn}_{0.1}\right) \mathrm{Fe}_{0.9} \mathrm{TiO}_{3}$, indicating pyrophanite extreme member proportion up to 23.9\%. Most intrusions of the Aguas Claras group presented ilmenite also, and these are also $\mathrm{Mn}$ bearing (around 6.0wt\%). Calculated structural formula for dacites (Ap2, Ap4 and Ap5) is $\left(\mathrm{Mn}_{0.1} \mathrm{Fe}^{3+}{ }_{0.2}\right) \mathrm{Fe}^{2+}{ }_{0.8} \mathrm{Ti}_{0.9} \mathrm{O}_{3}$ where $\mathrm{Fe}^{3+}$ content is remarkable, indicating pyrophanite and hematite extreme members proportions up to $13.8 \%$ and $16.6 \%$, respectively.

As described above, magmatic magnetite is subordinated in the Marmato group, calculated structural formula from EPMA analyses of intrusions (P1 and P3) is $\left(\mathrm{Ti}_{0.1} \mathrm{Al}_{0.1}\right) \mathrm{Fe}^{2+}{ }_{1.1} \mathrm{Fe}^{3+}{ }_{1.7} \mathrm{O}_{4}$. By the other hand, hydrothermal magnetite is dominant in 
intrusions (AP1, Ap2 and AP5) from the Aguas Claras group. Calculated structural formula is $\left(\mathrm{Fe}^{2+} \mathrm{Fe}^{3+}{ }_{1.9} \mathrm{O}_{4}\right)$ with contents less than $0.1 \%$ of ( $\mathrm{Ti}, \mathrm{Al}$, and $\left.\mathrm{V}\right)$. Nadoll et al, (2014), suggest that lower titanium contents are common in hydrothermal magnetites which are consistent with textural observations and calculated formulas from magmatic magnetites in the Marmato group and hydrothermal magnetites in the Aguas Claras group. Magmatic magnetite in the Aguas Claras group is not clearly recognize nor by petrographic nor by elemental composition at least with the available data. 
Table 3 Representative EPMA oxides analysis in the MACS, recalculated to 4 oxygens and 3 cations (Magnetites) and 3 oxygens and 2 cations (ilmenites). Mag (M): Magmatic magnetite; Mag (H): Hydrothermal magnetite; and Il: Ilmenite.

\begin{tabular}{ccccccccccccc} 
& $\mathbf{S i O}_{2}$ & $\mathbf{T i O}_{2}$ & $\mathbf{A l}_{2} \mathbf{O}_{3}$ & $\mathbf{F e}_{2} \mathbf{O}_{3}$ & $\mathbf{F e O}$ & $\mathbf{M n O}$ & $\mathbf{M g O}$ & $\mathbf{C a O}$ & $\mathbf{N i O}$ & $\mathbf{C r}_{2} \mathbf{O}_{3}$ & $\mathbf{V}_{2} \mathbf{O}_{3}$ & $\mathbf{T o t a l}$ \\
Mag (M) & 0.057 & 3.653 & 2.130 & 59.274 & 34.650 & 0.348 & 0.054 & 0.000 & 0.000 & 0.049 & 0.419 & $\mathbf{1 0 0 . 6}$ \\
$\quad$ Il & 0.062 & 52.560 & 0.013 & 0.000 & 32.525 & 14.246 & 0.045 & 0.149 & 0.000 & 0.023 & 0.377 & $\mathbf{1 0 0 . 0}$ \\
$\quad$ Il & 0.000 & 52.250 & 0.000 & 0.588 & 39.127 & 7.561 & 0.016 & 0.144 & 0.000 & 0.000 & 0.348 & $\mathbf{1 0 0 . 0}$ \\
& & & \multicolumn{7}{c}{ Aguas Claras porphyry group } \\
Mag (H) & 0.012 & 2.238 & 0.540 & 63.799 & 33.097 & 0.372 & 0.001 & 0.000 & 0.000 & 0.052 & 0.658 & $\mathbf{1 0 0 . 8}$ \\
$\quad$ Il & 0.075 & 47.199 & 0.000 & 9.910 & 36.677 & 5.706 & 0.049 & 0.000 & 0.000 & 0.011 & 0.439 & $\mathbf{1 0 0 . 1}$
\end{tabular}




\subsubsection{U-Pb age determinations}

We carried out U-Pb LA-ICP-MS ages determinations on zircons rims from ten drill core porphyry intrusion rock samples from the MACS, including intrusions P1-P5 and AP1AP5. The analyzed zircons are euhedral, prismatic and elongated, up to $175 \mu \mathrm{m}$ in size, and pink. Backscattering images, show that zircons display igneous oscillatory and sector zoning (Hoskin and Schaltegger, 2003), and neither recrystallization nor hydrothermal characteristics were seen. Old inherited zircon cores have not been observed; nevertheless it was detected by analyzing zircon cores where large variations in ${ }^{206} \mathrm{~Pb} /{ }^{238} \mathrm{U}$ ages exist. Additionally slightly older zircons were also distinguished which represents zircons crystallized earlier in the same magmatic system.

The obtained ages from zircon rims are considered to be crystallization age for each intrusion. Analyzed zircons from MACS intrusions are presented in (Annex 4-Annex 5) (Wendt and Carl, 1991). Weighted average age plots are shown in Figure 20.

Porphyry dacite P1 yielded a weighted average ${ }^{206} \mathrm{~Pb} /{ }^{238} \mathrm{U}$ age of $6.576 \pm 0.075 \mathrm{Ma}$ for the eleven younger zircons analyzed). Porphyry dacite P2 yielded a weighted average ${ }^{206} \mathrm{~Pb} /{ }^{238} \mathrm{U}$ age of $6.38 \pm 0.13 \mathrm{Ma}$ for the seven younger zircons analyzed) which is coherent with the older age of P1. Porphyry andesite P3 yielded a weighted average ${ }^{206} \mathrm{~Pb} /{ }^{238} \mathrm{U}$ age of $6.32 \pm 0.12 \mathrm{Ma}$ for the six younger zircons analyzed), which is coherent with the older age of P2. Porphyry Andesite P4 yielded a weighted average ${ }^{206} \mathrm{~Pb} /{ }^{238} \mathrm{U}$ age of $6.42 \pm 0.17 \mathrm{Ma}$ for the four younger zircons analyzed). Porphyry Dacite P5 yielded a weighted average ${ }^{206} \mathrm{~Pb} /{ }^{238} \mathrm{U}$ age of $5.75 \pm 0.11 \mathrm{Ma}$ for the six younger zircons analyzed), which is coherent with the older ages of intrusions P1 to P4.

In the Aguas Claras group the micro-granodiorite intrusion AP1 yielded a weighted average ${ }^{206} \mathrm{~Pb} /{ }^{238} \mathrm{U}$ age of $5.74 \pm 0.14 \mathrm{Ma}$ for the five younger zircons analyzed), which is a similar age to intrusion P5. Porphyry dacite AP2 yielded a weighted average ${ }^{206} \mathrm{~Pb} /{ }^{238} \mathrm{U}$ age of 6.46 $\pm 0.13 \mathrm{Ma}$ for the eight younger zircons analyzed), which represent the oldest intrusion of Aguas Claras group. Porphyry andesite AP3 yield a weighted average ${ }^{206} \mathrm{~Pb} /{ }^{238} \mathrm{U}$ age of $6.55 \pm 0.15 \mathrm{Ma}$ for the six younger zircons analyzed), which is not coherent with the younger age of AP2, although a younger age of intrusion AP3 compared with intrusion AP2 is possible within the internal error of the dates. Porphyry andesite AP4 yielded a weighted average ${ }^{206} \mathrm{~Pb} /{ }^{238} \mathrm{U}$ age of $6.48 \pm 0.14$ Ma for the nine younger zircons analyzed, which is coherent with the older ages of intrusions AP2 and AP3. Porphyry dacite AP5 yielded a weighted average ${ }^{206} \mathrm{~Pb} /{ }^{238} \mathrm{U}$ age of $6.253 \pm 0.090$ Ma for the ten younger zircons analyzed), which is coherent with the older ages of intrusions AP2 to AP4. 



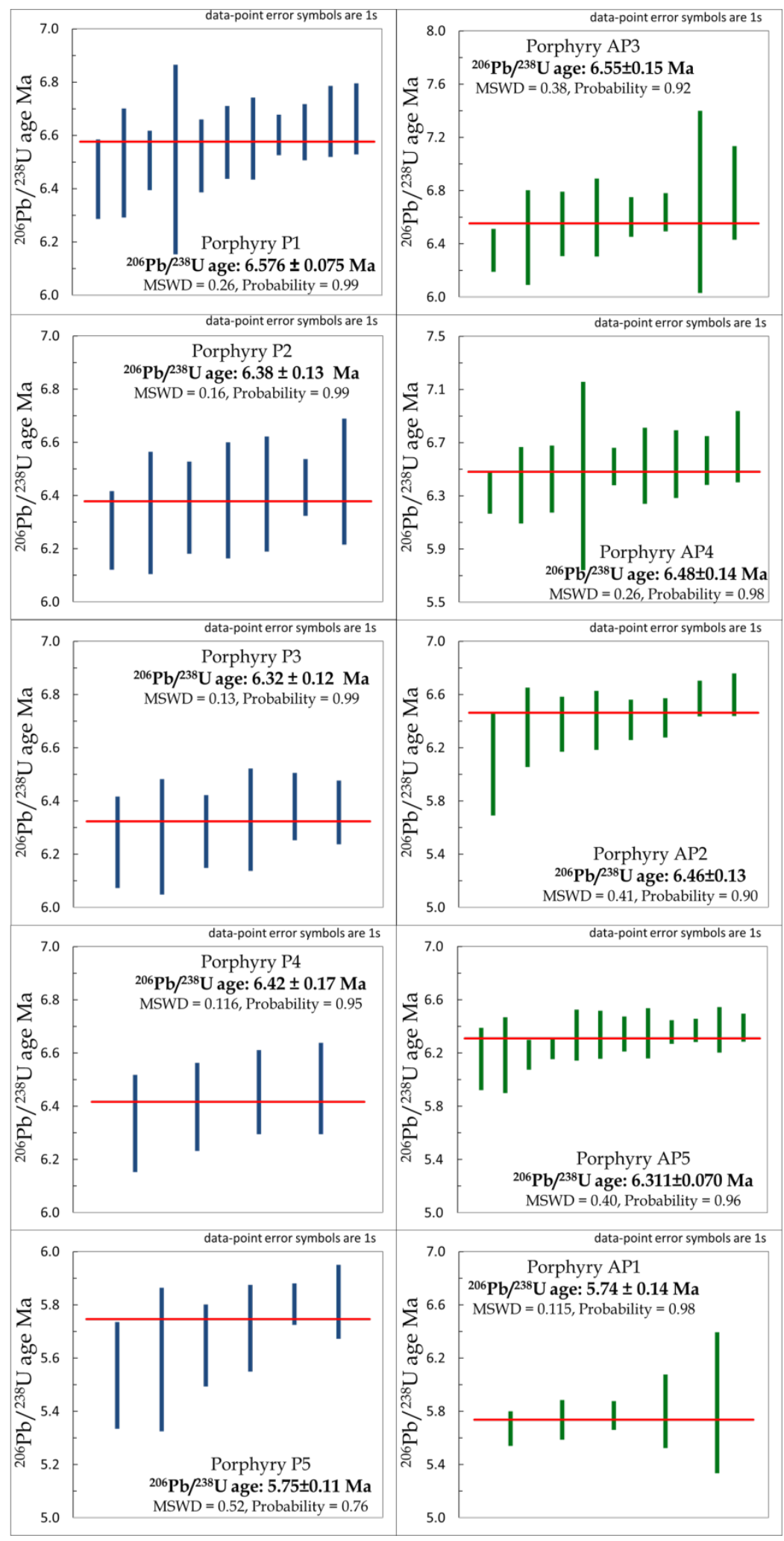

Figure 20 U-Pb LA-ICP-MS dating in zircons rims from the Marmato group (blue) and Aguas Claras group (Green). 
Figure 22 shows the relation between ages intrusions of MACS ( $\pm 1 \sigma$ uncertainty level). Ages are constrained between 6.6 to 5.7 Ma for MACS and the trend between older and younger intrusions in each group is similar. Taking into account the statistical uncertainly for each age, the results are comparable with the relative chronology established from cross cutting relationships observed in drill core. The exception is the intrusion AP1, which was reported by cross-cutting relationships as possibly the oldest intrusion of the Aguas Claras group; however, the cross cutting relationship of AP1 is not well defined and it was logged in only a single drill hole where it forms a dike-like intrusion surrounded by AP3. Dating show that AP1 is the youngest intrusion. In accordance with the coherence of dating and cross cut relations ships from all other intrusions of MACS, we suggest that the body AP1 is the youngest and not the oldest body in the Aguas Claras group as indicated by a single and possible misleading cross cut relationship.

Additionally, obtained ages are consistent with REE diagrams which display three different geochemical patterns in the MACS: 1) Younger intrusions with intermediate fractionation for MREE-HREE; 2) Intermediate age intrusions with low MREE-HREE; and 3) Older P5 intrusion with parallel but weaker fractionation for all REE in comparison with pattern 1 (Figure 15-Figure 16) AP1 intrusion show a geochemical consistent with pattern 1, but correspond to the older intrusion in the Aguas Claras group. This geochemical difference is consistent with petrographic between the granodiorite AP1 and the porphyry dacite P5. In general the MACS is enriched in LREE with flat HREE profiles and closely overlaps the compositional range of samples from Buritica and La Colosa.

\subsubsection{Age of mineralization by ${ }^{40} \mathrm{Ar} /{ }^{39} \mathrm{Ar}$ incremental heating}

${ }^{40} \mathrm{Ar} /{ }^{39} \mathrm{Ar}$ age spectra obtained from two hydrothermal adularia are presented in (Figure 21), and full analytical data are provided in (Annex 6-Annex 7). Plateau and ages were determined using the criteria of Dalrymple and Lanphere (1971) and Fleck et al. (1977), specifying the presence of at least three contiguous gas fractions that together represent more than 50 percent of the total ${ }^{39} \mathrm{Ar}$ released from the sample and for which no age difference can be detected between any two fractions at the 95 percent confidence level. Furthermore, the two adularia ages have also been calculated with the inverse isochron method (Annex 8-Annex 9), (McDougall and Harrison, 1999).

The two samples of adularia in vein (Upper mineralized zone) and veinlet (Lower mineralized zone) yielded similar ages, with well-defined plateaus at $5.96 \pm 0.02 \mathrm{Ma}$ and $6.05 \pm 0.02 \mathrm{Ma}$ (Figure 21). Isochron ages are respectively 5.06 $\pm 0.02 \mathrm{Ma}$ and $6.04 \pm 0.02$ Ma for the same samples (Figure 21). Spectrum shapes and initial 40Ar/36Ar ratios (295.7 \pm 2 and $297.8 \pm 2.8$ ) confirm that no excess ${ }^{40} \mathrm{Ar}$ is present. In both cases, the data points on the isochron plots are show a well distribution, so the plateau and isochron ages are 
considered reliable. The ages of the two samples is interpreted to represent the age of mineralization at Marmato. According to these results, the timing of mineralization is between the timing of porphyry magmatism at $6.576 \pm 0.075$ to $5.75 \pm 0.11$ Ma (Figure 22).
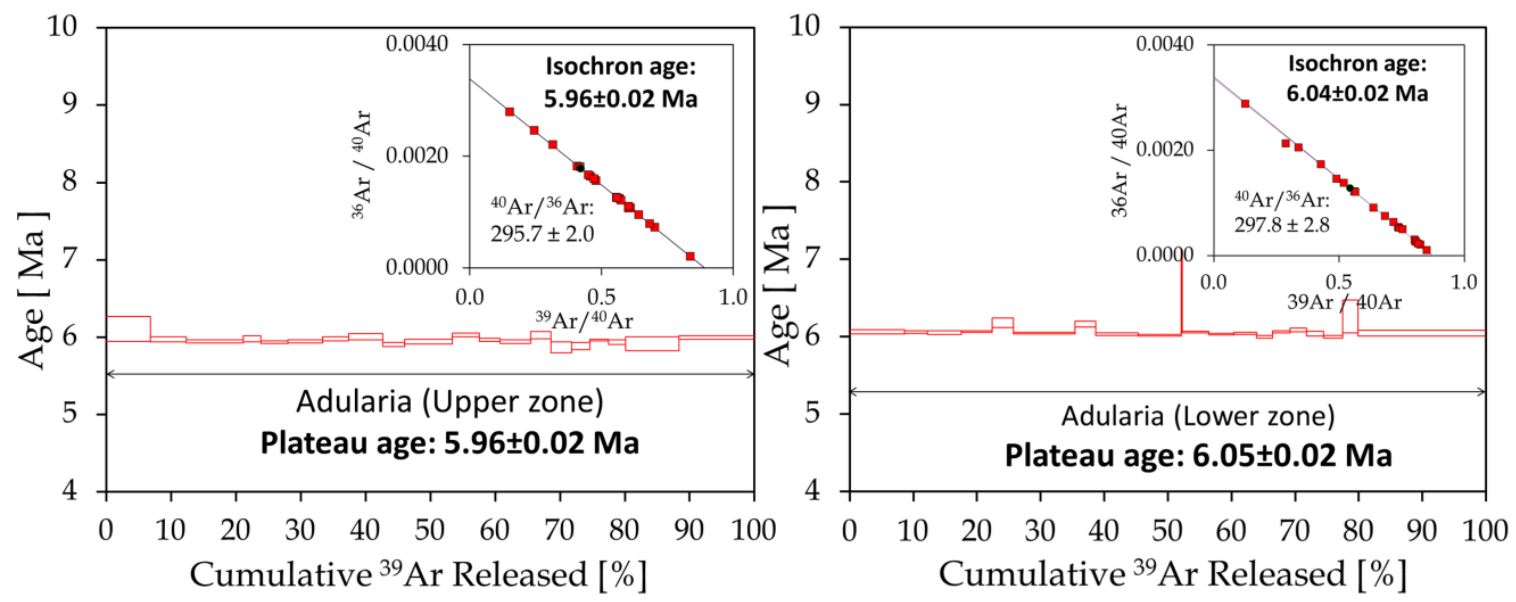

Figure 21. ${ }^{40} \mathrm{Ar} /{ }^{39} \mathrm{Ar}$ ages spectra for two hydrothermal adularia samples of the Marmato gold deposit which yield a valid plateau and isochron age. A. Hydrothermal adularia in vein (Upper zone). B. Hydrothermal adularia in veinlet (Lower zone). See text for discussion.

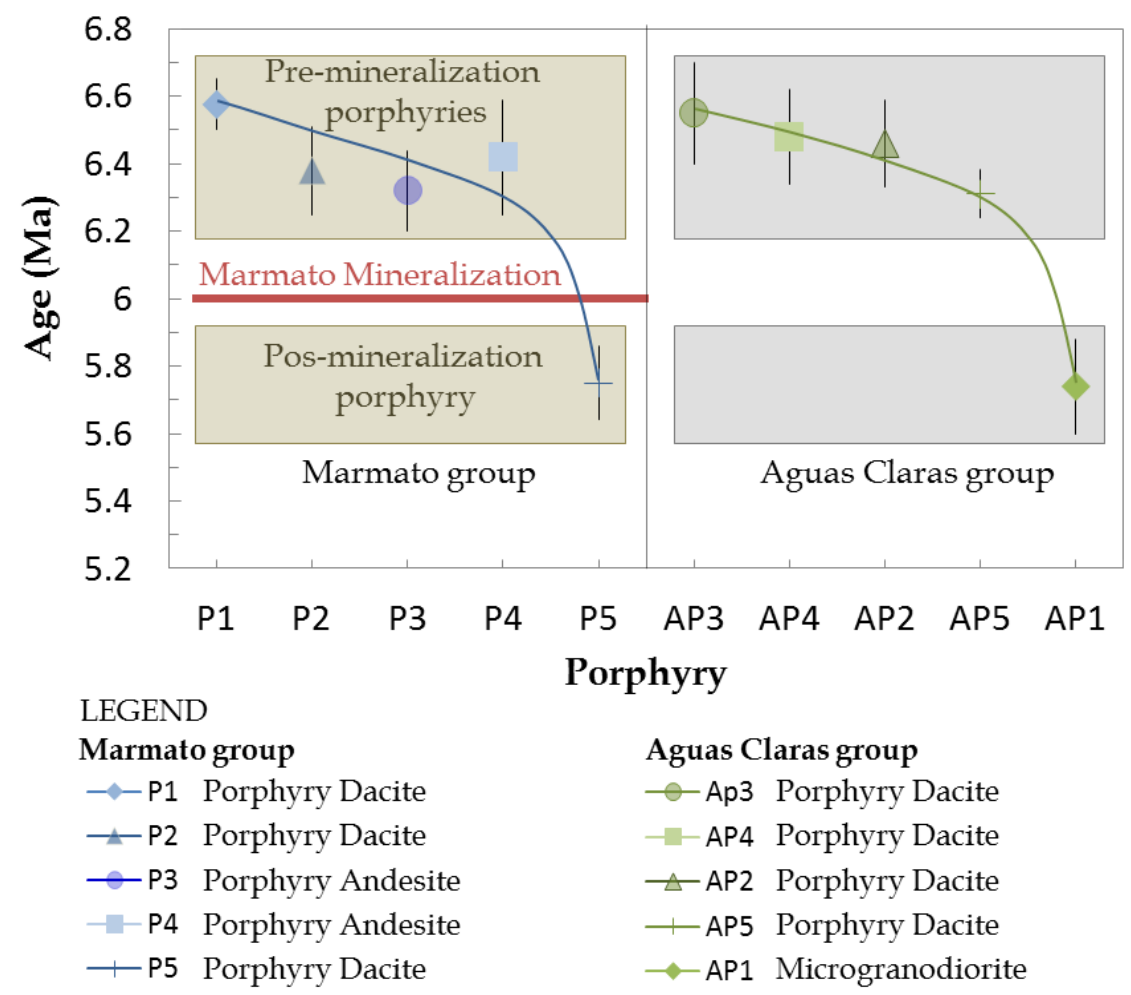

Figure 22 Relationship between U-Pb dating for MACS. Marmato mineralization age are represented by Ar-Ar hydrothermal adularia related to gold mineralization in the Marmato deposit. See text for discussion. 


\subsubsection{Sr-Nd Isotopes}

Sr-Nd isotope data for the MACS are listed in (Annex 10) and illustrated in Figure 23. Marmato and Aguas Claras rocks have ${ }^{87} \mathrm{Sr} /{ }^{86} \mathrm{Sr}$ ratios of 0.70435 to 0.70756 and 0.7045 to 0.70513 respectively, with narrow ranges of ${ }^{143} \mathrm{Nd} /{ }^{144} \mathrm{Nd}$ values of 0.512688 to 0.512935 and 0.512693 to 0.512898 respectively, and Tdm ages of $\sim 0.28$ to $0.54 \mathrm{Ga}$ and $\sim 0.22$ to $0.58 \mathrm{Ga}$, respectively. Tassinari et al (2008) indicate ${ }^{87} \mathrm{Sr} /{ }^{86} \mathrm{Sr}$ ratios of 0.70445 to 0.70460 with ${ }^{143} \mathrm{Nd} /{ }^{144} \mathrm{Nd}$ values of 0.512752 to 0.512802 for the principal host rock in the Marmato group which they describe as a porphyry dacite, consistent with P1, and therefore their SrNd data are used in order to plot P1 as well as quartz-gold veins.

Sr-Nd isotopic ratios from the MACS plot a cluster in the mantle-array field (Figure 23). Nevertheless some Sr-Nd isotopic signatures from porphyry rocks show a slightly displacement generated higher or lower values of ${ }^{143} \mathrm{Nd} /{ }^{144} \mathrm{Nd}$ and higher ${ }^{87} \mathrm{Sr} /{ }^{86} \mathrm{Sr}$. This Sr$\mathrm{Nd}$ isotopic variation in porphyries is explained by 1) the probably interaction with the continental crust as suggested by Sr-Nd values of crustal xenoliths or; 2) the inheritance variation of the magma source.

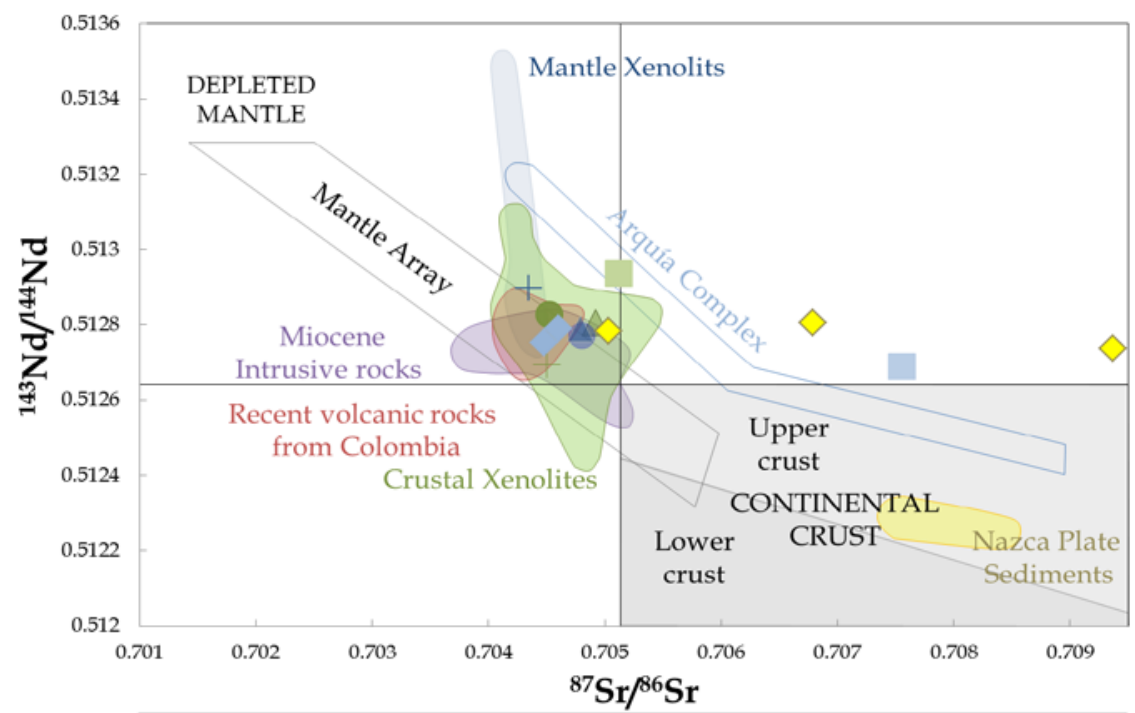

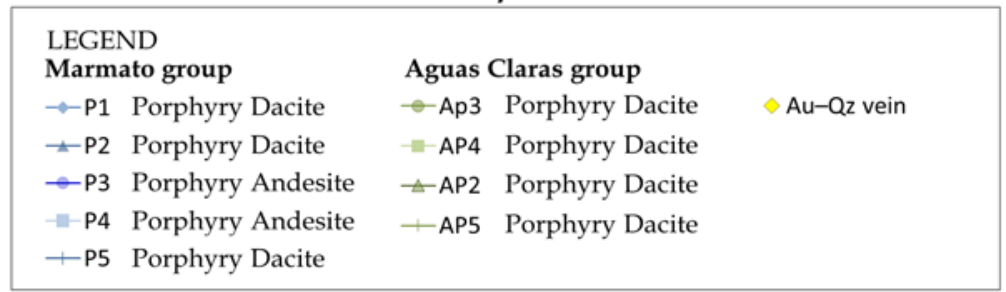

Figure $23{ }^{87} \mathrm{Sr} /{ }^{86} \mathrm{Sr}$ vs ${ }^{143} \mathrm{Nd} /{ }^{144} \mathrm{Nd}$. MACS are mostly plotted in the Mantle-array field, however crustal assimilation and hydrothermal alteration are suggested from the data (See text for disccussion). Modified after (Gil-Rodrihuez J., 2014), $\mathrm{Au}-\mathrm{Qz}$ vein data from (Tassinari et al., 2008). The ${ }^{87} \mathrm{Sr} /{ }^{86} \mathrm{Sr}$ ratios and ${ }^{143} \mathrm{Nd} /{ }^{144} \mathrm{Nd}$ are reported as present day values, because the measured values are very close to calculated values at the time of magmatism. 
In addition, the P4 porphyry intrusion shows relatively higher Sr values which were likely generated by the hydrothermal event as suggested by the Sr-Nd values of the quartz-gold veins.

\subsection{Discussion}

\subsubsection{Ages of the magmatism and Marmato gold mineralization}

Timing of the MACS magmatism is constrained between (6.58 \pm 0.07 to $5.74 \pm 0.14 \mathrm{Ma}$ ), while formation of adularia associated with Marmato gold mineralization in the upper and lower zones yielded between (6.05 \pm 0.02 to $5.96 \pm 0.02 \mathrm{Ma}$ ). Additionally, Marmato ages are consistent with petrography where porphyries P1 to P4 are pre-mineralization bodies $(6.576 \pm 0.075$ to $6.42 \pm 0.17 \mathrm{Ma})$ which hosted most of the mineralization that take place around (6.05 \pm 0.02 to $5.96 \pm 0.02 \mathrm{Ma}$ ), while porphyry P5 are pos-mineralization (5.75 \pm $0.11 \mathrm{Ma}$ ) (Figure 22). Aguas Claras group ages show a close similar behavior with this of the Marmato group, nevertheless petrography show that the younger porphyry Ap1 also hosted the mineralization suggesting that Aguas Claras mineralization may be younger that Marmato mineralization.

Timing of the magmatism is consistent with previous dating works carried out in Marmato in spite of none of these give a detailed location of the samples, nor or few specifications of the dating method used, nor more that the briefest description of the lithology, and in some cases no information at all. Age of P1 intrusion $(6.7 \pm 0.2$ to $6.5 \pm 0.2 \mathrm{Ma}$ by U-Pb SHRIMP) on zircon cores and rims, respectively (Frantz et al., 2003) are consistent with our data. Some additional ages are deduced from papers to correspond with porphyry P1, showing the cooling age of the P1 intrusion at $6.7 \pm 0.06$ Ma by Ar-Ar method in biotite (Vinasco, 2001), and a younger relative age of $6.3 \pm 0.7$ by K-Ar method on whole rock (Gonzalez, 1980, quoted in Sillitoe et al, 1982), the last with a bigger error and, in addition, maybe affected by propylitic alteration present around all the deposit. Finally (Rodrigues, 1987, quoted in: Rodriguez and Warden, 1993) published a K-Ar age of $7.1 \pm 0.2$ for andesite porphyry (possibly intrusion P4).

Additionally, important related late Miocene deposits in Colombia are: La Colosa (8 Ma by Gil-Rodriguez, 2010), Buritica (7.4 Ma by Lesage et al., 2013) and Yurumalito (7 Ma by Henrichs et al., 2014). All this deposits are part of a late and evolved magmatism that comprise from 30 to $3.5 \mathrm{Ma}$ (Aspden et al., 1987).

\subsection{2 “Adakite like” rocks}

Lithogeochemistry of MACS display and “Adakite like” behavior, in order to clarify some key aspects we realized a briefly descrition of the "Adakite like” rocks. 
The term "Adakite like" makes reference to rocks which display close similar characteristics with adakite rocks, but a different genetic process is assumed. Adakite rocks were first described by Kay (1978) for young andesites ( $<25 \mathrm{Ma}$ ) with a high magnesium content found in Adak Island in the Aleutians which are characterized by high La/Yb ratios and high concentrations of $\mathrm{Sr}(\sim 1800 \mathrm{ppm}), \mathrm{Mg}, \mathrm{Cr}$ and $\mathrm{Ni}$ compared with normal andesites. The author suggested that these geochemical characteristics are consistent with an origin of partial melt of the subducted oceanic crust, with partial reaction and equilibration with a wedge of asthenospheric mantle peridotite during ascent to the upper crust (see also Schiano et al., 1995; Kepezhinskas et al., 1995, 1996; Kelemen et al., (2014); Martin et al, (2005). Defant and Drummond (1990, 1993), Maury et al., (1996) quote in Martin et al., (2005) and Martin (1999) coined the term “adakites”, established the absence of a basalt member, and proposed geochemical graphics to differentiate between adakitic magmas and those derived from normal island arcs. Martin and Moyen (2003) and Champion and Smithies, (2003), independently proposed two main compositional adakite groups, which are defined based on the silica content as low silica (LSA; $\mathrm{SiO}_{2}<60$ weight $\%$ ) or primitive magnesian andesite, and high-silica (HSA; $\mathrm{SiO}_{2}>60$ weight \%) consisting of both silicic slab melt and slab melt that has equilibrated with mantle peridotite, where the high $\mathrm{Sr} / \mathrm{Y}$ and $\mathrm{La} / \mathrm{Yb}$ ratios depend mainly on the initial ratios, the stability of plagioclase during melting and crystallization, and the fractionation of amphiboles in hydrous mafic magmas (Zamora, 2000 quote in Martin et al., 2005; Castillo, 2012).

Additionally, the role of magmas derived from the partial fusion of the oceanic crust "adakites" as a source of metals in porphyry deposits has been suggested amply by different authors (Thiéblemont et al., 1997; Oyarzun et al., 2001; Reich et al., 2003; Sun et al., 2013; Sun et al., 2015), nevertheless it has been proposed that alternative crustal interaction and crystal fractionation process during the magma ascent are capable of generating an "adakite-like” signature without the need slab melt and are also linked to porphyry deposits (Richards and Kenrrich, 2007; Richards, 2011; and Richards et al., 2012).

Castillo, (2012) and Kelemen et al., (2014) present a very complete and interesting discussion about the different controversial points around adakites and related primitive magmas, and point out that the term "adakite” had been misused, commonly referring both to a rock name and to a specific genetic process, but it relies on trace element chemistry for its distinguishing characteristics.

\subsubsection{Tectonic setting and characteristics of the magma}

The tectonic setting of the Colombian Andes is characterized by subduction of young ( $<20$ $\mathrm{Ma}$ ) oceanic crust (Ramos and Folguera, 2009) beneath relative thin continental crust ( $<40$ Km) (Cediel and Caceres, 2000; Cediel et al., 2003). Benniof zone is located around 140- 
$200 \mathrm{Km}$ under the volcanic belt in the Colombian Andes which has remained almost the same during the last 10Ma (Pennington, 1981; James \& Murcia, 1984; Gustscher et. al., 1999 and Vargas \& Mann, 2013) and is deeper in comparison with the "adakite window" located between 75 and $85 \mathrm{Km}$ where melting of the subducted oceanic crust occur (Drummond \& Defant, 1990). Rocks younger than 5 Ma with geochemical “Adakite like” signatures have been reported previously in the late Miocene to recent rocks in the Colombian Andes (Toro et al., 2008; Borrero et al., 2009).

The geochemistry of the MACS is consistent with "Adakite like” rocks, where some critical

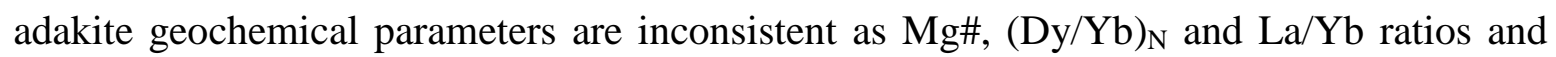
$(\mathrm{Ni}, \mathrm{Cr})$ content. $(\mathrm{Dy} / \mathrm{Yb})_{\mathrm{N}}>1.5$ ratio values have been suggested to demonstrate garnet fractionation (Kelemen et al., 2014), while a high Mg\# ( $>0.5)$ could indicate a possible, but not necessary, adakite origin (Castillo, 2012; Kelemen et. al., 2014). Nevertheless, none of these values are consistent with the MACS (Table 2). Instead we can interpret $(\mathrm{Dy} / \mathrm{Yb})_{\mathrm{N}}<$ 1.5 to be the result of amphibole fractionation (Kelemen et al., 2014) and consistent with REE diagrams (Figure 15-Figure 16) which show typical flat to listric-shaped patterns also reflecting amphibole fractionation which preferentially partitions MREE (Castillo et al., 1999; Richards, 2011). High Sr/Y ratios (>55) could been generated by an alternative process such as crystal fractionation (Castillo et al., 1999; Richards and Kenrrich, 2007; Castillo, 2012), while low Mg\# values $(<0.5)$ are characteristic of evolved melts (Kelemen et al., 2014).

Amphibole stability in magmas is achieved in relatively high $\mathrm{H}_{2} \mathrm{O}$ concentrations $(\geq 4$ weight \%) (Ridolfi et al., 2010), which in turn will suppress plagioclase on the liquidus until after the appearance of hornblende (Moore and Carmichael, 1998; Kelemen et al., 2014). $\mathrm{Eu}_{\mathrm{N}} / \mathrm{Eu}^{*}$ anomalies of $0.75-1.1$ from the MACS are in agreement with the above, suggesting high magmatic water contents or a high magmatic oxidation state which would either suppress plagioclase fractionation or cause Eu be present in the trivalent state in the melt, which does not partition into plagioclase (Frey et al., 1978; Hanson, 1980; Sisson and Grove, 1993). High water contents are consistent with amphibole fractionation. Evidence for the voluminous precipitation of amphibole in the MACS is evidenced by the amphibolerich porphyries (P1-P5 and AP1-AP5), usually accompanied with biotite.

By the other side, oxidized and reduced type igneous rocks can be distinguished on the basis of the magnetite content in the rocks which is mainly controlled by the redox state of components in the magma, additionally ilmenite could be the dominant oxide in oxidized type magmas where just few magnetites crystal occur (Ishihara, 1977; Takagi \& Tsukimura, 1997). MACS can be classified as oxidized type - magnetite series magmas where Mn-ilmenite is the most common oxide. 
Frost (1991), pointed out that a rock that crystallized at relatively oxidized conditions, but containing ilmenite as the major oxide, will follow a relatively oxidizing cooling trend, similar to rocks with and $\mathrm{H}_{2} \mathrm{O}$-rich fluid by the reaction between oxides, K-feldspar and biotite. Stabilization of ilmenite at high $\mathrm{fO}_{2}$ instead of magnetite, due to high Mn contents would be influence the departure of the classic magnetite - ilmenite oxide assemblage (Czamanske \& Mihálik, 1972; Czamanske et al. 1977). Abundant Mn-ilmenite was crystallized in an early magmatic stage, suggesting that MACS departs from a melt that was already oxidized and follows a Mn-ilmenite trend. By follow this trend the $\mathrm{fO}_{2}$ may reach that of the ilmenite-hematite solvus, causing hematite to exsolve from the ilmenite (Geuna et al., 2008), nevertheless the cooling trend did not get the ilmenite - hematite solvus in the Marmato group but was closer in the Aguas Claras group as indicate the higher (16.6\%) hematite solid solution proportion. Regardless the fact that cooling trend did not get the ilmenite - hematite solvus in the MACS, the final $\mathrm{fO}_{2}$ may have been higher that the initial (Figure 24). Hydrothermal anhydrite in the intrusion AP1 is also consistent with these high $\mathrm{fO}_{2}$ magmas (Imai, 2001; Sun et al., 2015). The initial high $\mathrm{fO}_{2}$ in the MACS may have also generated the absence of a Eu anomaly.

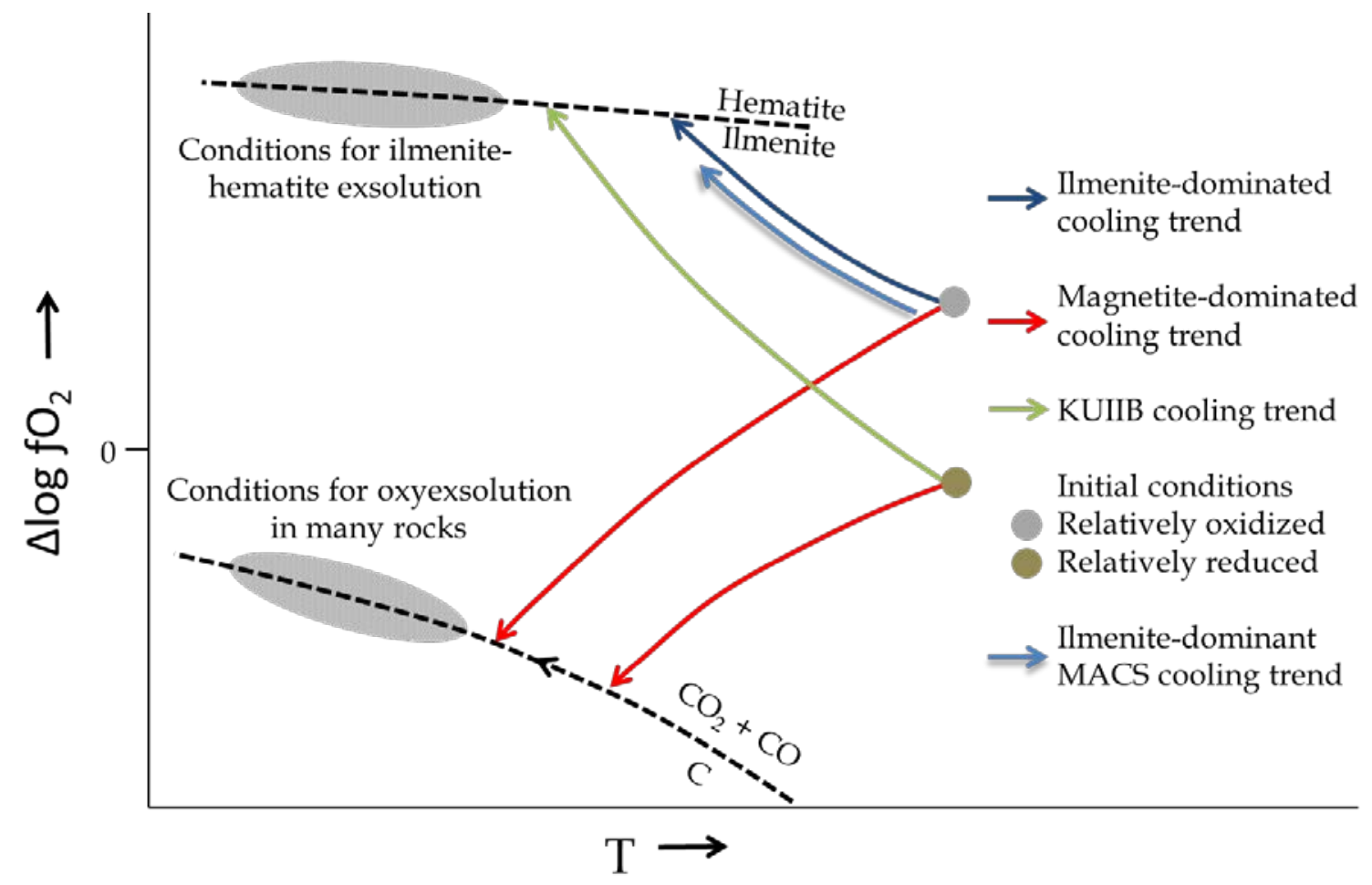

Figure $24 \Delta \log \mathrm{fO}_{2}-\mathrm{T}$ diagram showing inferred cooling trends for Fe-Ti oxides, after Frost (1991). MACS cooling trend is close to the inferred ilmenite-dominated cooling trend, nevertheless ilmenite-hematite solvus was not reached. 


\subsubsection{Source of the magma and comparison with related igneous rocks in Colombia}

Almost all Sr-Nd isotopic compositions for the MACS are plot in the mantle field Figure 23 , with a slightly variation generated by probably weak interaction with the continental crust or the inheritance variation of the magma source, unless they has been affected by hydrothermal fluids such as porphyry P4. It is difficult to demonstrate or discard a minor magmatic contribution resulting from the partial melting of the Nazca plate although the position of the Benniof zone under the volcanic belt in the Colombian Andes, and the absent of garnet fractionation evidence suggest that melting have not taken place.

Our observations for MACS are consistent with La Colosa, Buriticá and late Miocene and Recent volcanic rocks which show similar lithogeochemical patterns (Marriner and Millward, 1984; Cepeda, 1985; Thouret et al., 1995; Druox and Delaloye, 1996; Calvache et al., 1997; Correa et al., 2000; Dominguez et al., 2003; Borrero et al., 2009, and Lesage et al., 2013), and Sr-Nd isotopic compositions (James and Murcia, 1984; Calvache and Williams, 1997; Ordoñez and Pimentel, 2001; Tassinari et al., 2008, Gil-Rodriguez J., 2010, 2014), constantly display that magma contamination must have been minimal due to the different values show by the basement rocks of the Central cordillera in Colombia (Mantle and Crustal Xenolits and Arquía Complex in Figure 23). Petrogenetic models are also similar.

According to the above the most probable source of the magma (MACS) might be originated by partial melting of the mantle wedge by fluids (minimal melt if existing) from the subducted slab and/or sediments, followed by processes of crystal fractionation and minimal crustal contamination at high $\mathrm{fO}_{2}$ - hydrous conditions, which is also consistent with petrogenetic models of (Richards, 2003; and Candela \& Piccoli, 2005).

\subsubsection{Implications for mineralization and regional exploration}

As describe above, ages and petrogenetic models for the generation of MACS, La Colosa, Buriticá and late Miocene to Recent igneous rocks in Colombia are very similar. Notwithstanding, Marmato gold deposit shows a remarkable mineralization style specially at depth (Lower Zone), which differ from La Colosa porphyry type and the epithermal type of Buriticá. Mineralization in the Marmato group are associated with pyrrhotitechalcopyrite-pyrite veinlets commonly accompanied by bismuth, while most intrusions from the Aguas Claras group are related to veinlets with magnetite-chalcopyrite-pyrite, strongly suggesting different $\mathrm{fO}_{2}$ and $f \mathrm{~S}_{2}$ or diverse evolution paths of the hydrothermal fluids derived from a similar oxidized type - magnetite series suite (MACS).

The primary assemblage, with both abundant magmatic Mn-ilmenite and minor magmatic magnetite had important consequences for the rock magnetism of the MACS, resulting in 
medium low magnetic susceptibility values and a strong reduction of the natural remanent magnetization (NRM) intensities, especially for the Marmato group where magmatic Mnilmenite is the most abundant oxide mineral. Moreover, stronger ferrimagnetic hydrothermal magnetite may help to form a medium high anomaly in the Aguas Claras group while weaker ferromagnetic hydrothermal pyrrhotite contributes to a lesser extent in the Marmato group. Comparable conclusions have been reported for similar oxide mineral associations (Geuna et al., 2008; McEnroe et al., 2001). This is corroborated by aeromagnetic images for the MACS which show a medium low anomaly for the Marmato group and a medium high anomaly for the Aguas Claras group, the latter where mostly hydrothermal magnetite is the most abundant oxide mineral but where magmatic Mnilmenite is also important (Figure 25).

Discussion about genesis of the different hydrothermal mineral association and characterization of the Marmato gold deposit are interesting topics and will be the subject of an additional paper.

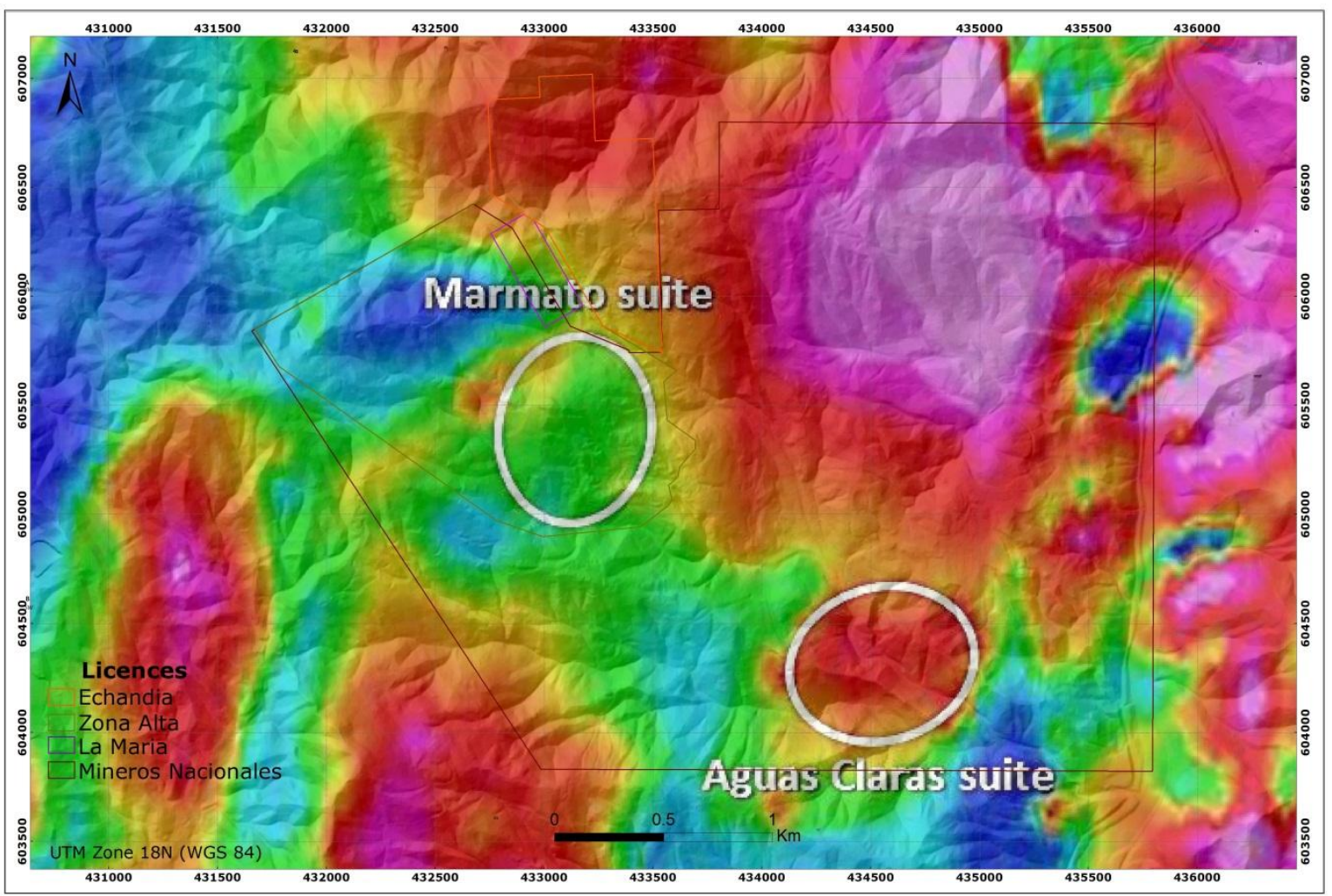

Figure 25 Aeromagnetic survey. Reduced to the Pole image superimposed on a DEM background over the MACS. Note the medium low anomaly for the Marmato group where magmatic Mn-ilmenite is the most abundant oxide mineral and a medium high anomaly for the Aguas Claras group where hydrothermal and lesser magmatic magnetite are the most abundant oxide minerals. 


\subsection{Conclusions}

The Marmato and Aguas Claras suite (MACS) comprise mostly andesites to dacites porphyry rocks which hosted one of the most important gold deposit in the Middle Cauca belt, an epithermal (Upper zone) to veinlet type (Lower zone) gold mineralization in the Marmato group and a related porphyry gold mineralization in the Aguas Claras group. Ages of the magmatism for the MACS has been constrained between (6.58 \pm 0.07 to $5.74 \pm 0.14$ $\mathrm{Ma})$. In the case of the Marmato gold deposit we distinguished between pre-mineralization porphyries $\mathrm{P} 1$ to $\mathrm{P} 4(6.576 \pm 0.075$ to $6.42 \pm 0.17 \mathrm{Ma}$ ) which hosted the mineralization that occur at (6.05 \pm 0.02 to $5.96 \pm 0.02 \mathrm{Ma}$ ) and pos-mineralization porphyry P5 (5.75 \pm 0.11 Ma).

The geochemistry of the MACS is consistent with calk-alkaline to high-K calk-alkaline “Adakite like” rocks with $(\mathrm{Dy} / \mathrm{Yb})_{\mathrm{N}}<1.5$, high $\mathrm{Sr} / \mathrm{Y}(>55)$ and low $\mathrm{La} / \mathrm{Yb}(<20)$ ratios, low Mg\# values ( $<0.5)$, REE diagrams with a typical flat to listric-shaped pattern, belonging to the oxidized type - magnetite series magmas, reflecting evolved melts generated in a volcanic environment where a young slab ( $<20 \mathrm{Ma})$ are subducted under a thin continental crust $(<40 \mathrm{Km})$ and benniof zone is located around $140-200 \mathrm{Km}$ beneath the volcanic belt since the late Miocene. Magma may be originated by partial melting of the mantle wedge by fluids (minimal melt if existing) from the subducted slab and/or sediments followed by minimal crustal contamination as suggested by Sr-Nd compositions and by processes of amphibole fractionation at high $\mathrm{fO}_{2}$ - hydrous conditions, suppressing plagioclase on the liquidus until after the appearance of amphibole, and generating a weak or no Eu anomaly. High initial $\mathrm{fO}_{2}$ also favoring the Mn-ilmenite crystallization which may be followed a relatively oxidizing cooling trend further increasing the $\mathrm{fO}_{2}$, and consistent with hydrothermal anhydrite.

Similarities between the MACS and other rocks of the late Miocene-Recent volcanic including those of La Colosa and Buritica gold deposits in the Middle Cauca metallogenic belt are significant, including host-rock geochemistry, Sr-Nd isotopic compositions and age, oxides cannot be compare because unfortunately most of those does not show any information, nonetheless similar petrogenetic models can be assumed. This geochemical signatures are preliminary a good regional exploration criteria for melts capable that produced porphyry to epithermal Au-Cu-Ag-minor Mo deposits specially in the late Miocene volcanic belt in colombian Andes as pointed out by (Richards, 2011; Richards et al., 2012) in other similar environments, but efforts must be continued in order to differentiate between fertile and barren melts.

The magmatic - hydrothermal mineral association is relevant for the rock magnetism of the MACS. In the Marmato gold deposit abundant magmatic Mn-ilmenite and minor magnetite 
plus hydrothermal pyrrhotite resulting in medium low magnetic susceptibility, while in the Aguas Claras deposit the presence of hydrothermal magnetite instead of pyrrhotite generated medium high magnetic susceptibility. As preliminar observations in the Marmato gold deposit display a remarkable mineralization style at depth, associated with pyrrhotitechalcopyrite-pyrite veinlets commonly accompanied by bismuth, differing from the Aguas Claras group related to veinlets with magnetite-chalcopyrite-pyrite, suggesting diverse $\mathrm{fO}_{2}$ and $f S_{2}$ characteristics in the hydrothermal fluids derived from a similar magmatic suite (MACS), the understanding of magmatic - hydrothermal mineral association is important for the exploration of targets similar to the Marmato gold deposit.

\subsection{Acknowledgments}

This study formed part of the senior author's MSc thesis and was supported by the Brasilia University and CAPES agency, Brazil, which provided a scolarship to L.R. Santacruz. The authors are grateful to the Brazilian National Council for Research (CNPq) for the financial support by means of the projects 550266/2011-9 and 305833/2010-3. The National University of Colombia is acknowledged for partial electron microprobe analyses supporter, Gran Colombia Gold Corp. for the help with the field work, providing samples from drill holes and technical reports, and SEG foundation by a fellowship that greatly contribute in the advance of the senior author's MSc thesis. We thank Juliana Plazas and Carolina Jiménez of National University of Colombia for analytical support and technical assistance. Comments by José Carlos Frantz and Claudinei Gouveia de Oliveira on an early version of the manuscript as part of the Ms.C. thesis were appreciated. 


\section{CAPITULO 5: CONCLUSÕES}

A suíte de Marmato e Aguas Claras (MACS) é constituída principalmente por andesitos e dacitos pórfiro, as quais hospedam um dos maiores depósitos de ouro no cinturão do Cauca Médio, uma mineralização de ouro epitermal (zona superior) a qual muda para tipo vênula (zona inferior) no grupo Marmato e uma mineralização de ouro do tipo pórfiro relacionada com o grupo Aguas Claras. A idade do magmatismo para o MACS é limitada entre (6,58 \pm 0,07-5,74 $\pm 0,14 \mathrm{Ma}$ ). No caso do depósito de Marmato, nós distinguimos entre intrusões pré-mineralização P1 a P4 (desde 6,576 \pm 0,075 até 6,42 $\pm 0,17 \mathrm{Ma}$ ) os quais hospedam a mineralização que ocorre aos $(6,05 \pm 0,02$ até $5,96 \pm 0,02 \mathrm{Ma})$ e a intrusão posmineralização P5 (5,75 \pm 0,11 Ma).

A geoquímica do MACS é consistente com rochas cálcio-alcalinas a cálcio-alcalinas de alto potássio, com assinatura "semelhante aos Adakitos" com (Dy/Yb) $\mathrm{N}<1,5$, alta relação $\mathrm{Sr} / \mathrm{Y}$ ( $>55)$ e baixa $\mathrm{La} / \mathrm{Yb}(<20)$, baixo valores $\mathrm{Mg \#}(<0,5)$, e diagramas de REE com um padrão típico plano ou em forma de lístrica, pertencentes a magmas oxidados da serie magnetita, refletindo magmas evoluídos gerados em um ambiente vulcânico, onde uma jovem crosta oceânica ( $<20 \mathrm{Ma}$ ) é subductada por embaixo de uma crosta continental fina ( $<40 \mathrm{~km})$, e a zona de benniof situa-se em torno de 140-200 Km abaixo do cinturão vulcânico desde o final do Mioceno. O magma pode ter sido gerado pela fusão parcial da cunha do manto por fluidos da crosta subductada e/ou sedimentos (fusão mínima, se existente) seguido de uma mínima contaminação da crosta continental como sugerido pelas composições Sr-Nd e continuado por processos de fraccionamento de anfibólio em condições de alta fO2 e hidratação, suprimindo a plagioclasa no liquidus até depois do aparecimento de anfibólio, e gerando uma fraca ou nenhuma anomalia de UE. A alta fO2 inicial também favoreceu a cristalização Mn-ilmenita que pode ter seguido uma tendência de resfriamento relativamente oxidante aumentando ainda mais a $f \mathrm{O} 2$, e consistente com a ocorrência de anidrita hidrotermal.

Existem semelhanças significativas entre os MACS e outras rochas vulcânicas do final do Mioceno até o Recente, incluindo aquelas dos depósitos de ouro de La Colosa e Buritica localizados no cinturão metalogenético do Cauca Médio, incluindo, geoquímica, composições isotópicas Sr-Nd e idades, os óxidos não podem ser comparados devido que, infelizmente, a maioria dos estúdios não apresenta este tipo de informação, no entanto modelos petrogenéticos semelhantes podem ser assumidos. Esta assinatura geoquímica é um bom critérios de exploração regional preliminar para magmas capazes de produzir depósitos Au-Cu-Ag- menor Mo do tipo pórfiro para épitermal especialmente no cinturão vulcânico do final do Mioceno nos Andes colombianos como apontado por (Richards, 
2011; Richards et al. , 2012) em outros ambientes similares, entretanto os esforços devem prosseguir na direção de conseguir diferenciar entre magmas férteis e estéreis.

A associação mineral magmática-hidrotermal é relevante para o magnetismo das rochas do MACS. No depósito de ouro Marmato abundante Mn-ilmenita de origem magmatico e em menor proporção magnetita mais pirrotita hidrotermal resulta numa susceptibilidade magnética meio-baixa, enquanto no deposito de Aguas Claras depositar a presença de magnetita hidrotermal em vez de pirrotita gera uma susceptibilidade magnética meio-alta. Como as observações preliminares no depósito de ouro de Marmato mostram um estilo de mineralização notável em profundidade, associado com vênulas com pirrotita-calcopiritapirita comumente acompanhada de bismuto, diferindo do grupo Aguas Claras relacionado com vênulas com magnetite-calcopirita-pirita, sugerindo diversas características na fO2 e fS2 nos fluidos hidrotermais derivados de uma suíte magmática semelhante (MACS), a compreensão da associação mineral magmática-hidrotermal é importante para a exploração de alvos semelhantes ao depósito de ouro Marmato. 


\section{REFERÊNCIAS BIBLIOGRÁFICAS}

Alvarez J.A., 1983. Geologia de la Cordillera Central y el occidente colombiano y petroquimica de los intrusivos granitoides meso-cenozoicos: Boletín Geologico, Ingeominas, Vol. 26, n. 2, 175 p.

Annen, C., Blundy, J.D., and Sparks, R.S.J., 2006, The genesis of intermediate and silicic magmas in deep crustal hot zones: Journal of Petrology, v. 47, p. 505-539.

Aspden J.A., McCourt W.J., and Brook M., 1987. Geometrical control of subductionrelated magmatism: the Mesozoic and Cenozoic plutonic history of western Colombia. Journal of the Geological Society, London, Vol 144, pp 893-905.

Baldwin, J.A., and Pearce, J.A., 1982, Discrimination of productive and nonproductive porphyritic intrusions in the Chilean Andes: Economic Geology, v. 77, p. 664-674.

Bedoya O. G. S., 1998. Geology, Hydrothermal alteration, paragenetic sequence and fluid inclusion of La Maruja level, Marmato district, Caldas Department, Colombia. Degree document of Master of Science, Colorado State University, Fort Collins, Colorado, 164 pp.

Borrero C., Toro L. M., Alvarán M. and Castillo H., 2009. Geochemistry and tectonic controls of the effusive activity related with the ancestral Nevado del Ruiz volcano, Colombia. Geofísica Internacional, vol. 48 - 1, pp 149 - 169.

Bühn B., Pimentel M.M., Matteini M., and Dantas E.L., 2009. High spatial resolution analysis of $\mathrm{Pb}$ and $\mathrm{U}$ isotopes for geochronology by laser ablation multi-collector inductively coupled plasma mass spectrometry (LA-MCICPMS). Annals of the Brazilian Academy of Sciences, Vol. 81: 99-114.

Caceres C., Cediel F. and Etayo. F., 2003. Guía Introductoria de la Distribución de Facies Sedimentarias de Colombia - Compendio del armazón estructural y de la geología sedimentaria de Colombia, cuyo fundamento fáctico está registrado en mapas a escala 1:1’000.000.: Ingeominas, 45 p., 18 mapas. Formato análogo y digital.

Calle B., González H., de la Peña R., Escorce E. and Durango J., 1984. Mapa Geológico Preliminar. Plancha No. 186 - Riosucio Instituto Nacional de Investigacion Geologico Minera, Informe 1878 (1980), 1 map at 1:100,000 scale.

Calvache V.M.L., and Williams S.N., 1997.Geochemistry and petrology of the Galeras Volcanic Complex, Colombia. Journal of Volcanology and Geothermal Research, v. 77, p. 21-38. 
Campbell C.J., 1974, Colombian Andes, in Spencer A.M., ed., Mesozoic-Cenozoic Orogenic Belts: Geological Society of London Special Publications, Vol. 4, p. 705-724.

Candela P. A., and Piccoli P. M., 2005. Magmatic processes in the development of porphyry-type ore systems: Economic geology 100th anniversary volume, pp. 25-37.

Castillo P.R., 2012. Adakite petrogenesis, Lithos v. 134-135, p. 304-316.

Castillo, P.R., Janney, P.E., Solidum, R., 1999. Petrology and geochemistry of Camiguin Island, southern Philippines: insights into the source of adakite and other lavas in a complex arc tectonic setting. Contributions to Mineralogy and Petrology, v. 134, p. 33-51.

Cediel F., Leal-Mejia H., Shaw R.P., Melgarejo J.C. and Restrepo-Pace P.A., 2011. Regional geology of Colombia. Petroleum geology of Colombia, ANH, 224 pp.

Cediel, F., and C. Cáceres, 2000, Geological Map of Colombia, Third Edition: Geotec Ltd., Bogotá, digital format with legend and tectonostratigraphic chart.

Cediel, F., R. P. Shaw, and C. Cáceres, 2003, Tectonic assembly of the Northern Andean Block, in C. Bartolini, R. T. Buffler, and J. Blickwede, eds., The Circum-Gulf of Mexico and the Caribbean: Hydrocarbon habitats, basin formation, and plate tectonics: AAPG Memoir 79, pp. 815-848.

Cepeda H., 1985. Anotaciones acerca de la geología del Volcán Galeras (Colombia, S. A.): Sexto Congreso Latinoamericano de Geología, pp. 338-383.

Champion, D.C., Smithies, R.H., 2003. Slab melts and related processes-Archaean versus Recent. In: Arima, M., Nakajima, T., Ishihara, S. (Eds.), Hutton Symposium V, The Origin of Granites and Related Rocks. Geological Survey of Japan, pp. 19.

Correa A. M., Cepeda H., Pulgarín B., and Ancochea E., 2000. El Volcán Nevado del Huila (Colombia): Rasgos generales y caracterización composicional: Geogaceta, V. 27, pp. 5154.

Czamanske G.K, Wones D.R. and Eichelberger J.C, 1977. Mineralogy and Petrology of the Intrusive Complex of the Pliny Range, New Hampshire. American Journal of Science, v. 277, p. 1073-1123.

Czamanske G.K., and Mihálik P., 1971. Oxidation During Magmatic Differentiation, Finnrnarka Complex, Oslo Area, Norway: Part 1, The Opaque Oxides, Journal of Petrology, v. 13-3, p. 493-509. 
Dalrymple, G.B., and Lanphere, M.A., 1971, 40Ar/39Ar technique of K-Ar dating: A comparison with the conventional technique: Earth and Planetary Science Letters, v. 12, p. 300-308.

Defant M. J. and Drummond M. S. (1990) Derivation of some modern arc magmas by melting of young subducted lithosphere. Nature 347, 662-665.

Defant M. J. and Drummond M. S. 1993, Mount St. Helens: Potential example of the partial melting of the subducted lithosphere in a volcanic arc: Geology, v. 21, p. 547-550.

Domínguez L., Concha, A. E., and Cepeda H., 2003, Volcán Cerro Machín: Mecanismo eruptivo, transporte y sedimentación (Tolima, Colombia): Geología Colombiana, V. 28, pp. 3-21.

Droux A., and Delaloye M., 1996, Petrography and geochemistry of Plio-Quaternary calcalkaline volcanoes of southwestern Colombia: Journal of South American Earth Sciences, V. 9, pp. 27-41.

Drummond, M.S., Defant, M.J., 1990. A model for trondhjemite-tonalite-dacite genesis and crustal growth via slab melting: Archaean to modern comparisons. Journal of Geophysical Research 95, 21503-21521.

Duque-Caro H., 1990. The Choco Block in the northwestern corner of South America: structural, tectonostratigraphic, and paleogeographic implications. Journal of South American Earth Sciences 3, 71-84.

Durán R., et al., 2005. Complementación Geológica, Geoquímica y Geofísica (Magnetométrica) de las Planchas 166, 167, 186 y 187, Escala 1:100,000, IGAC, Zona de Influencia del Sector Caucal-Romeral. Report by Union Temporal Dunia ATG (Dunia Consultores Ltda \& Asesorias Técnicas Geológicas), Bogotá, 462 p.

Ego F., Sebrier M., 1995. Is the Cauca-Patía and Romeral fault system left- or right-lateral? Geophysical Research, Letters 22, 33-36.

Etayo F., Barrero D. and others, 1983, Mapa de Terrenos de Colombia: Publicaciones Geológicas Especiales INGEOMINAS, n. 14-1, 235 p.

Fleck, R.J., Sutter, J.F., and Elliot, D.H., 1977, Interpretation of discordant 40Ar/39Ar age spectra of Mesozoic tholeiites from Antarctica: Geochimica and Cosmochimica Acta, v. 41, p. 15-32. 
Frantz, J.C., Ordoñez O. C., Franco E., Groves D. I., and McNaughton, N. J., (2003). Marmato Porphyry Intrusion, Ages and Mineralization. Memorias IX Congreso Colombiano de Geologia, Medellin, Sociedad Colombiana de Geologia, v. 1, p. 54-55.

Frey, F.A., Chappell, B.W., and Roy, S.D., 1978, Fractionation of rare-earth elements in the Tuolumne Intrusive Series, Sierra Nevada batholith, California: Geology, v. 6, p. 239242.

Frost, B.R., 1991. Magnetic petrology: factors that control the occurrence of magnetite in crustal rocks, in Oxide Minerals: Petrologic and Magnetic Significance, Reviews in Mineralogy, v. 25, p. 489-509.

Gansser, A. 1973, Facts and theories on the Andes. Journal of the Geological Society of London, v. 129, p. 93-131.

Geuna S. E.,McEnroe, S. A., Robinson P., and Escosteguy L. D., 2008, Magnetic petrology of the Devonian Achala Batholith, Argentina: titanohaematite as an indicator of highly oxidized magma during crystallization and cooling: Geophys. J. Int., v. 175, p. 925-941.

Gil-Rodriguez J., 2010, Igneous Petrology of The Colosa Gold-Rich Porphyry System (Tolima, Colombia). Degree Document, Professional Science Master, In the Graduate College, The University Of Arizona, 51 pp.

Gil-Rodriguez J., 2014, Petrology of the Betulia Igneous Complex, Cauca, Colombia. Journal of South American Earth Sciences vol 56, pp 339-356.

Gioia, S.M.C.L., Pimentel, M.M. 2000. The Sm-Nd Isotopic Method in the Geochronology Laboratory of the University of Brasília. Anais da Academia Brasileira de Ciências, v.72-2, p. 219-245.

Gómez T.J., Montes R.N.E., Nivia G.A., and Diederix H. (compiladores), 2015. Mapa Geológico de Colombia: INGEOMINAS, Escala 1:1’000.000, 2 p.

Green, T.H., and Pearson, N.J., 1985, Experimental determination of REE partition coefficients between amphibole and basaltic to andesitic liquids at high pressure: Geochimica et Cosmochimica Acta, v. 49, p. 1465-1468.

Gustscher M. A., Malavieille J., Lallemand S \& Collot J. Y., 1999. Tectonic segmentation of the North Andean margin: impact of the Carnegie Ridge collision. Earth and Planetary Sciences Letters, 168, p. 255-270. 
Hanson, G.N., 1980, Rare earth elements in petrogenetic studies of igneous systems: Annual Review of Earth Planetary Sciences, v. 8, p. 371-406.

Henrichs I. A., Frantz J. C., Marques J.C., Ordoñes O. C., Castoldi M. S., and Sato K., (2014) Caracterização e geocronologia SHRIMP U-Pb em zircão das rochas subvulcânicas do sistema pórfiro Yarumalito, Distrito de Marmato, Colômbia. Pesquisas em Geociências, v. 41-3, p. 231-242.

Hildreth W. and Moorbath S. (1988) Crustal contributions to arc magmatism in the Andes of central Chile. Contrib. Mineral. Petrol. 98, p. 455-489.

Hoskin, P., and Schaltegger, U., 2003, The composition of zircon and igneous and metamorphic petrogenesis: Reviews in Mineralogy and Geochemistry, Vol. 53, p. 27-62.

Imai, A., 2001. Generation and evolution of ore fluids for porphyry $\mathrm{Cu}-\mathrm{Au}$ mineralization of the Santo Tomas II (Philex) deposit, Philippines. Resource Geology, v. 51-2, p. 71-96.

Ishihara S., 1977. The Magnetite-series and Ilmenite-series Granitic Rocks, Mining Geology, v. 27, p. 293-305.

James, D. \& Murcia, L., 1984. Crustal contamination in northern Andean volcanics. Journal of the Geological Society London, 141, p. 823-830.

Kay R. W. (1978) Aleutian magnesian andesites: melts from subducted Pacific ocean crust. J. Volcanol. Geotherm. Res.4, 117-132.

Kelemen, P.B., Hanghøj, K., and Greene, A.R., 2014. One view of the geochemistry of subduction-related magmatic arcs, with an emphasis on primitive andesite and lower crust: Treatise on Geochemistry $2^{\text {nd }}$ Ed, p. 749-805.

Kepezhinskas, P.K., Defant, M.J., Drummond, M.S., 1995. Na-metasomatism in the island arc mantle by slab melt-peridotite interaction: evidence from mantle xenoliths in the north Kamchatka arc. Journal of Petrology, v. 36, p. 1505-1527.

Kepezhinskas, P.K., Defant, M.J., Drummond, M.S., 1996. Progressive enhancement of island arc mantle by melt-peridotite interaction inferred from Kamchatka adakites. Geochimica et Cosmochimica Acta, v. 60, p. 1217-1229.

Košler J., Fonneland H., Sylvester P., Tubrett M and Pedersen R.B., 2002. U-Pb dating of detrital zircons for sediment provenance studies - a comparison of laser ablation ICMPS and SIMS techniques. Chemical Geology, Vol. 182, p. 605-618. 
Le Bas, M.J., Maitre, R.W., Streckeisen, A., and Zanettin, B., 1986, A chemical classification of volcanic rocks based on the total alkali-silica diagram: Journal of Petrology, v. 27, p. 745-750.

Leal-Mejía, H., 2011, Phanerozoic Gold Metallogeny in the Colombian Andes - A tectonomagmatic approach: Ph.D. thesis, Barcelona (Catalonia), Spain, University of Barcelona, 1000p.

Le-Maitre R.W., 2002. Igneous rocks - a classification and glossary of terms. Recommendations of the IUGS subcommission on the Systematics of Igneous Rocks . Cambridge: Cambridge University Press. $2^{\text {nd }}$ edn.

Lesage G., Richards J. P., Muehlenbachs K., and Spell T. L., 2013. Geochronology, geochemistry, and fluid characterization of the late Miocene Buritica gold deposit, Antioquia Deparment, Colombia. Economic Geology, vol. 108, pp 1067-1097.

Lodder C., Padilla R., Shaw R., Garzon T., Palacio E. and Jahoda, R., 2010. Discovery history of the La Colosa Gold Porphyry deposit, Cajamarca, Colombia: Society of Economic Geologists Special Publication 15, p. 19-28.

López A., Sierra G.M. and Ramirez D.A., 2006. Vulcanismo Neogeno en el suroccidente antioqueño y sus implicaciones tectonicas: Boletín de Ciencias de la Tierra, n.19, p. 27-42.

López, L., 1982, Características geoquímicas de rocas ígneas asociadas con pórfidos cupríferos chilenos: Revista Geológica de Chile, no. 17, p. 3-19.

Loucks R.R., 2014, Distinctive composition of copper-ore-forming arcmagmas, Australian Journal of Earth Sciences, Australian Journal of Earth Sciences: An International Geoscience Journal of the Geological Society of Australia, 14 pp.

Lugmair, G.W., Marti, K. 1978. Lunar initial 143Nd/144Nd: Differential evolution of the lunar crust and mantle. Earth Planetary Science Letters, v. 39, p. 349-357.

Mantilla L.C., Valencia V.A., Barra F., Pinto J. and Colegial J., 2009, U-Pb geochronology from porphyry rocks in the Vetas-California gold mining area (Santander, Colombia): Boletín de Geología (UIS), v. 31, n.1, p. 31-43.

Marriner G. F., and Millward D., 1984. The petrology and geochemistry of Cretaceous to Recent volcanism in Colombia: The magmatic history of an accretionary plate margin: Journal of the Geological Society of London, V. 141, pp. 473-486. 
Martin, H., 1999, Adakitic magmas: Modern analogues of Archaean granitoids: Lithos, v. 46, p. 411-429.

Martin, H., Moyen, J.-F., 2003. Secular changes in TTG composition: comparison with modern adakites. EGS-AGU-EUG joint meeting, Nice, April, VGP7-1FR2O-001.

Martin, H., Smithies, R.H., Rapp, R. Moyen, J.-F., and Champion, D., 2005, An overview of adakite, tonalite-trondhjemite-granodiorite (TTG), and sanukitoid: relationships and some implications for crustal evolution: Lithos, v. 79, p. 1-24.

Maury, R.C., Sajona, F.G., Pubellier, M., Bellon, H., Defant, M.J., 1996. Fusion de la croute oceanique dans les zones de subduction/collision recentes: l'exemple de Mindanao (Philippines). Bull. Soc. Geol. Fr. 167 (5), 579- 595.

McDougall, I., and Harrison, T. M., 1999. Geochronology and Thermo-chronology by the 40Ar/39Ar Method. 2nd ed., Oxford Univ. Press, Oxford, UK.

McEnroe, S.A., Robinson, P. and Panish, P.T., 2001. Aeromagnetic anomalies, magnetic petrology, and rock magnetism of hemo-ilmenite- and magnetite-rich cumulate rocks from the Sokndal Region, South Rogaland, Norway, American Mineralogy, v. 86, p.1447-1468.

Moore, G.M., and Carmichael, I.S.E., 1998, The hydrous phase equilibria (to 3 kbar) of an andesite and basaltic andesite from western Mexico: Constraints on water content and conditions of phenocryst growth: Contributions to Mineralogy and Petrology, v. 130, p. 304-319.

Muller, R.D., Sdrolias M., Gaina C., and Roest W.R., 2008. Age, spreading rates and spreading symmetry of the world's ocean crust, Geochemistry Geophysics Geosystems, v. 9, $19 \mathrm{p}$.

Mungall, J.E., 2002. Roasting the mantle: slab melting and the genesis of major Au and Au rich $\mathrm{Cu}$ deposits. Geology, v. 30, p. 915-918.

Nadoll P., Angerer T., Mauk J.L., French D., Walshe J., 2014. The chemistry of hydrothermal magnetite: A review, Ore Geology Reviews, Vol. 61, p. 1-32.

Nebel, O., Scherer, E.E., Mezger, K., 2011. Evaluation of the 87Rb decay constant by age comparison against the U-Pb system. Earth and Planetary Science Letters, v. 301, p. 1-8.

Ordoñez, O. and Pimentel, M.M., 2001, Geoquímica isotópica del magmatismo reciente (<11Ma), en los Andes Colombianos: Congreso Colombiano de Geología, VII, Manizales, 2001. 
Oyarzun, R., Márquez, A., Lillo, J., López, I., and Rivera, S., 2001, Giant versus small porphyry copper deposits of Cenozoic age in northern Chile: Adakitic versus normal calcalkaline magmatism: Mineralium Deposita, v.36, p. 794-798.

Parsons, B., 2012. A NI 43-101 Mineral Resource Estimate on the Marmato Project, Colombia, 21 June 2012. Report for Gran Colombia Gold Corp. by SRK Consulting (UK) Limited, 3 August 2011, 187 p., published on SEDAR at www.sedar.com .

Peccerillo A., \& Taylor S.R., 1976, Geochemistry of Eocene calc-alkaline volcanic rocks from the Kastamonu area, northern Turkey: Contributions to Mineralogy and Petrology, Vol. 58, p. 63-81.

Pennington , W., 1981. Subduction of the eastern Panamá Basin and seismotectonics of northwestern South America. Journal of Geophysical Research, 86, B11: 10753-10770.

Pindell, J., Kennan, L., 2009. Tectonic evolution of the Gulf of Mexico, Caribbean and northern South America in the mantle reference frame: an update. In: James, K., Lorente, M.A., Pindell, J. (Eds.), The geology and evolution of the region between North and South America: Geological Society of London Special Publication, 328, pp. 1-55.

Ramos V. A., and Folguera A., 2009. Andean flat-slab subduction through time, from Muphy J.B., Keppie J.D., and Hynes A.J., (eds) Ancient Orogens and Modern Analogues. Geological Society, London, special publications, 327, pp 31-54.

Redwood, S.D., 2011. The History of the Marmato Gold Mine, Colombia. Unpublished report for Gran Colombia Gold Corp., 66 p.

Reich, M., Parada, M.A., Palacios, C., Dietrich, A., Schultz, F., and Lehmann, B., 2003, Adakite-like signature of late Miocene intrusions at the Los Pelambres giant porphyry copper deposit in the Andes of central Chile: Metallogenic implications: Mineralium Deposita, v. 38, p. 876-885.

Restrepo J.J., \& Toussaint J.F., 1988. Terrains and continental accretion in the Northern Andes: Episodes, Vol. 11, n. 3, p. 189-193.

Restrepo J.J., Toussaint J., and Gonzales H., 1981. Edades miopliocénicas del magmatismo asociado a la Formação Combia, Departamento de Antioquia y Caldas. Geología Norandina, Vol. 3, 21-26.

Richards J. P, Spell T., Rameh E., Razique A., Fletcher T., 2012. High Sr/Y Magmas Reflect Arc Maturity, High Magmatic Water Content, and Porphyry Cu $\pm \mathrm{Mo} \pm \mathrm{Au}$ 
Potential: Examples from the Tethyan Arcs of Central and Eastern Iran and Western Pakistan: Economic Geology, v. 107, pp. 295-332

Richards J. P., 2003. Tectono-magmatic precursors for porphyry Cu-(Mo-Au) deposit formation: Economic geology, V. 98, pp. 1515-1533.

Richards, J.P., 2011. High Sr/Y Arc Magmas and Porphyry Cu \pm Mo \pm Au Deposits: Just Add Water, Economic Geology, v. 106, p.1075-1081.

Richards, J.P., and Kerrich, R., 2007. Adakite-like rocks: Their diverse origins and questionable role in metallogenesis: Economic Geology, v. 102, p.537-576.

Ridolfi, F., Renzulli, A., and Puerini, M., 2010, Stability and chemical equilibrium of amphibole in calc-alkaline magmas: An overview, new thermobarometric formulations and application to subduction-related volcanoes: Contributions to Mineralogy and Petrology, v. 160, p. $45-66$.

Rodriguez C., and Warden A.J., 1993. Overview of some Colombian gold deposits and their development potential. Mineralium Deposita 28, pp 47-57.

Rossetti P., and Colombo F., 1999. Adularia-sericite gold deposits of Marmato (Caldas, Colombia): field and petrographical data. In: Mccaffrey K. J. W., Lonergan L. and Wilkinson J. J., (eds). Fractures, Fluid Flow and Mineralization. Geological Society, London, Special Publications, 155, pp 167-182

Santacruz R. L., 2010. Microtermometria De Inclusiones Fluidas Aplicada Al Depósito De Marmato: Trabajo de Grado, Departamento de Geociencias, Universidad Nacional de Colombia-Sede Bogotá, pp 23 y Anexos.

Schiano P., Clocchiatti R., Shimizu N., Maury R.C., Jochum K.P., and Hofmann A.W., 1995. Hydrous, silica-rich melts in the sub-arc mantle and their relationship with erupted arc lavas. Nature, v.377, pp 595-600.

Schmidbauer E., 1987, ${ }^{57}$ Fe Mössbauer spectroscopy and magnetization of cation deficient $\mathrm{Fe}_{2} \mathrm{TiO}_{4}$ and $\mathrm{FeCr}_{2} \mathrm{O}_{4}$. PartI: ${ }^{57} \mathrm{Fe}$ Mössbauer spectroscopy, Physics and Chemistry of Minerals v. 14, p. 533-541.

Shagam R., 1975. The northern termination of the Andes, in Nairn, A.E.M. \& Stehli, F.G., eds., The Ocean Basins and Margins: New York, Plenum Press, v. 3, p. 325-420. 
Shagam, R., 1975, The northern termination of the Andes, in Nairn, A.E.M., and Stehli, F.G., eds., The ocean basins and margins, v. 3: The Gulf of Mexico and the Caribbean: New York, Plenum Press, p. 325-420.

Sillitoe R. ., 2008. Major gold deposits and belts of the north and South aermican Cordillera: Distribution, tectonomagmatico, and Metallogenic Considerations. Economic Geology, vol 103, pp 663- 687.

Sillitoe R.H., and Hart S.R., 1984. Lead-isotopic signatures of porphyry copper deposits in oceanic and continental settings, Colombia Andes. Geochimica et Cosmochimica Acta, Vol 48, pp 2135-2142.

Sillitoe R.H., Jaramillo L., Damon P. E., Shafiqullah M., Escovar R., 1982. Setting, Characteristics, and Age of the Andean porphyry cooper belt in Colombia. Economic Geology, vol 77, pp 1837-1850.

Sisson T.W., and Grove T.L., 1993. Experimental investigations of the role of H2O in calcalkaline differentiation and subduction zone magmatism. Contributions to Mineralogy and Petrology, v.113, p. 143-166.

Sun W-D., Huang R-F., Li H., Hua Y-B., Zhang C-C., Sun S-J., Zhang L-P., Ding X., Li CY., Zartmana R.E., Ling M-X., 2015. Porphyry deposits and oxidized magmas, Ore Geology Reviews, Vol. 65, p. 97-131.

Sun W-d., Liang H-y., Ling M-x., Zhan M-z., Ding X., Zhang H., Yang X-y., Li Y-l., Ireland T. R., Wei Q-r., Fan W-m., 2013. The link between reduced porphyry copper deposits and oxidized magmas, Geochimica et Cosmochimica Acta, 103, pp 263-275.

Sun, S.S., and McDonough, W.F., 1989, Chemical and isotopic systematics of oceanic basalts: Implications for mantle composition and processes: Geological Society of London Special Publication, v. 42, p. 313-345.

Taboada A., Rivera L.A., Fuenzalida A., Cisternas A., Philip H., Bijwaard H., Olaya J., and Rivera C., 2000. Geodynamics of the northern Andes - Subductions and intracontinental deformation (Colombia), Tectonics, Vol. 19, n. 5, p. 787-813.

Takagi T., and Tsukimura K., 1997. Genesis of Oxidized and Reduced-Type Granites, Economic Geology, vol 92, pp. 81-86.

Tassinari C.C.G., Pinzon F.D., and Ventura J. B., 2008. Ages and sources of gold mineralization in the Marmato mining district, NW Colombia: A Miocene-Pliocene epizonal gold deposit. Ore Geology Reviews, vol. 33, pp. 505-518. 
Thiéblemont, D., Stein, G., Lescuyer, J.L., 1997. Epithermal and porphyry deposits: the adakite connection. Comptes Rendus de l'Académie des Sciences, Paris 325, pp 103-109.

Thouret J. C., Cantagrel J. M., Robin C., Murcia A., Salinas R., and Cepeda H., 1995. Quaternary eruptive history and hazard-zone model at Nevado del Tolima and Cerro Machín volcanoes, Colombia: Journal of Volcanology and Geothermal Research, V. 66, pp. 397-426.

Toro L.M., Alvarán M.E., Borrero C.A., 2008. Rocas con afinidad Adakitica al sur-este de Manizales: Rasgos petrogenéticos y geoquímicos. Boletín de Geología, Vol. 30-2. p. 49-60.

Toussaint J.F. \& Restrepo J.J., 1988. Cenozoic arc magmatism of northwestern Colombia: Geological Society of America, Special Paper 241, p. 205-212.

Vargas C.A \& Mann P., 2013. Tearing and Breaking Off of Subducted Slabs as the Result of Collision of the Panama Arc-Indenter with Northwestern South America, Bulletin of the Seismological Society of America, Vol. 103, No. 3, p. 2025-2046.

Vinasco, C.J., 2001. A utilização da metodologia ${ }^{40} \mathrm{Ar}-{ }^{39} \mathrm{Ar}$ para o estudo de reativações tectônicas em zonas de cisalhamento. Paradigma: O Falhamento de Romeral nos Andes Centrais da Colômbia. Unpublished M.Sc. thesis, Instituto de Geociências, Universidade de São Paulo, 85 pp.

Wendt I., \& Carl C., 1991, The statistical distribution of the mean squared weighted deviation: Chemical Geology, Vol. 86, p. 275-285.

Zamora, D., 2000. Fusion de la croute oceanique subductee: approche experimentale et geochimique. Universite Thesis Universite Blaise Pascal, Clermont-Ferrand, 314 pp 


\section{ANEXOS}

Annex 1 EPMA magnetites analysis in the MACS, recalculated to 4 oxygens and 3 cations.

\section{Marmato porphyry group}

\begin{tabular}{|c|c|c|c|c|c|c|c|c|c|c|c|c|}
\hline & $\mathrm{SiO}_{2}$ & $\mathrm{TiO}_{2}$ & $\mathbf{A l}_{2} \mathbf{O}_{3}$ & $\mathrm{Fe}_{2} \mathbf{O}_{3}$ & FeO & MnO & MgO & $\mathrm{CaO}$ & $\mathrm{NiO}$ & $\mathrm{Cr}_{2} \mathrm{O}_{3}$ & $\mathbf{V}_{2} \mathbf{O}_{3}$ & Total \\
\hline \multirow{4}{*}{ SD135 } & 1.608 & 1.891 & 0.479 & 56.859 & 31.821 & 0.056 & 0.004 & 1.097 & 0.000 & 0.000 & 0.259 & 94.1 \\
\hline & 0.000 & 2.399 & 0.051 & 60.621 & 31.606 & 0.122 & 0.000 & 0.000 & 0.000 & 0.020 & 0.199 & 95.0 \\
\hline & 0.000 & 1.036 & 0.042 & 63.217 & 30.304 & 0.089 & 0.019 & 0.005 & 0.000 & 0.010 & 199 & 94.9 \\
\hline & 1.609 & 1.889 & 0.480 & 61.443 & 33.883 & 0.056 & 0.004 & 097 & 0.000 & 000 & 259 & 00.7 \\
\hline \multirow{6}{*}{ SD149 } & 0.057 & 3.653 & 2.130 & 59.274 & 34.650 & 0.348 & 0.054 & 0.000 & 0.000 & .049 & .419 & 00.6 \\
\hline & 0.081 & 3.760 & 2.558 & 58.799 & 35.081 & 0.267 & 0.053 & 0.000 & 0.000 & .097 & .391 & 01.1 \\
\hline & 0.106 & 4.032 & 2.121 & 58.716 & 34.987 & 0.454 & 0.110 & 0.000 & 0.000 & 0.079 & 0.394 & 101.0 \\
\hline & 0.132 & 3.744 & 2.425 & 58.848 & 35.023 & 0.272 & 0.087 & 0.000 & 0.000 & 0.046 & 0.413 & 101.0 \\
\hline & 0.099 & 4.057 & 2.469 & 58.600 & 35.382 & 0.378 & 0.065 & 0.000 & 0.000 & 0.043 & 0.464 & 101.6 \\
\hline & 0.066 & 3.634 & 2.700 & 59.297 & 35.135 & 0.227 & 0.081 & 0.000 & 0.000 & 0.048 & 0.444 & 01.6 \\
\hline \multicolumn{13}{|c|}{ Aguas Claras porphyry group } \\
\hline & $\mathrm{SiO}_{2}$ & $\mathrm{TiO}_{2}$ & $\mathrm{Al}_{2} \mathrm{O}_{3}$ & $\mathrm{Fe}_{2} \mathrm{O}_{3}$ & $\mathrm{FeO}$ & MnO & MgO & $\mathrm{CaO}$ & $\mathrm{NiO}$ & $\mathrm{Cr}_{2} \mathrm{O}_{3}$ & $\mathrm{~V}_{2} \mathrm{O}_{3}$ & otal \\
\hline \multirow{6}{*}{ SD256 } & 0.000 & 0.470 & 0.401 & 68.401 & 32.082 & 0. & 0.013 & 0.000 & 0.000 & 0.079 & 0.439 & 1.9 \\
\hline & 0.000 & 0.529 & 0.635 & 67.800 & 32.064 & 0.051 & 0.016 & 0.000 & 0.000 & 0.056 & 0.452 & 101.6 \\
\hline & 0.000 & 0.608 & 0.877 & 67.260 & 32.140 & 0.056 & 0.016 & 0.000 & 0.000 & 0.068 & 0.464 & 101.5 \\
\hline & 0.054 & 1.373 & 0.668 & 66.701 & 33.145 & 0.121 & 0.000 & 0.000 & 0.000 & 0.032 & 0.364 & 102.5 \\
\hline & 0.082 & 1.414 & 0.392 & 66.730 & 33.081 & 0.123 & 0.008 & 0.000 & 0.000 & 0.018 & 0.364 & 102.2 \\
\hline & 0.080 & 0.678 & 0.374 & 67.621 & 32.222 & 0.043 & 0.012 & 0.000 & 0.000 & 0.030 & 0.368 & 101.4 \\
\hline \multirow{9}{*}{ SD258 } & 0.000 & 0.417 & 0.182 & 70.184 & 32.477 & 0.051 & 0.011 & 0.044 & 0.000 & 0.023 & 0.293 & 103.7 \\
\hline & 0.076 & 0.463 & 0.538 & 69.905 & 32.983 & 0.037 & 0.000 & 0.000 & 0.000 & 0.056 & 0.315 & 04.4 \\
\hline & 0.032 & 0.249 & 0.154 & 70.454 & 32.423 & 0.069 & 0.001 & 0.000 & 0.000 & 0.034 & 0.310 & 03.7 \\
\hline & 0.136 & 0.247 & 0.117 & 70.723 & 32.732 & 0.0 & 0.054 & 0.000 & 0.000 & 0.032 & 0.351 & 04.4 \\
\hline & 0.049 & 0.184 & 0.062 & 71.184 & 32.617 & 0.040 & 0.027 & 0.000 & 0.000 & 0.024 & 0.370 & 104.6 \\
\hline & 0.063 & 0.295 & 0.701 & 69.925 & 32.711 & 0.049 & 0.021 & 0.000 & 0.000 & 0.003 & 0.339 & 104.1 \\
\hline & 0.108 & 0.311 & 0.296 & 69.687 & 32.470 & 0.057 & 0.013 & 0.000 & 0.000 & 0.026 & 0.336 & 103.3 \\
\hline & 0.064 & 0.312 & 0.318 & 70.239 & 32.608 & 0.055 & 0.011 & 0.000 & 0.000 & 0.000 & 0.302 & 103.9 \\
\hline & 0.030 & 0.258 & 0.242 & 70.588 & 32.460 & 0.091 & 0.037 & 0.000 & 0.000 & 0.004 & 0.318 & 104.0 \\
\hline \multirow{7}{*}{ SD260 } & 0.012 & 2.238 & 0.540 & 63.799 & 33.097 & 0.372 & 0.001 & 0.000 & 0.000 & 0.052 & 0.658 & 100.8 \\
\hline & 0.012 & 0.335 & 0.247 & 68.815 & 32.040 & 0.057 & 0.003 & 0.000 & 0.000 & 0.027 & 0.683 & 102.2 \\
\hline & 0.056 & 0.710 & 0.503 & 67.546 & 32.362 & 0.087 & 0.019 & 0.000 & 0.000 & 0.038 & 0.656 & 102.0 \\
\hline & 0.000 & 1.012 & 0.511 & 67.217 & 32.542 & 0.138 & 0.050 & 0.000 & 0.000 & 0.060 & 0.677 & 102.2 \\
\hline & 0.080 & 0.481 & 0.259 & 68.155 & 32.172 & 0.081 & 0.000 & 0.000 & 0.000 & 0.061 & 0.680 & 102.0 \\
\hline & 0.123 & 1.747 & 1.215 & 64.326 & 33.076 & 0.294 & 0.112 & 0.000 & 0.000 & 0.071 & 0.645 & 101.6 \\
\hline & 0.026 & 2.955 & 0.099 & 64.738 & 34.617 & 0.220 & 0.000 & 0.000 & 0.000 & 0.095 & 0.466 & 103. \\
\hline
\end{tabular}


$\begin{array}{llllllllllll}0.000 & 2.324 & 0.151 & 65.331 & 33.720 & 0.180 & 0.024 & 0.000 & 0.000 & 0.083 & 0.475 & 102.3\end{array}$

$\begin{array}{llllllllllll}0.088 & 2.387 & 0.120 & 65.426 & 34.130 & 0.183 & 0.000 & 0.000 & 0.000 & 0.088 & 0.524 & 102.9\end{array}$ 
Annex 2. EPMA ilmenites analysis in the Marmato porphyry group, recalculated to 3 oxygens and 2 cations.

\section{Marmaro porphyry group}

$\begin{array}{lllllllllllllll}\mathrm{SiO}_{2} & \mathrm{TiO}_{2} & \mathrm{Al}_{2} \mathrm{O}_{3} & \mathrm{Fe}_{2} \mathrm{O}_{3} & \mathrm{FeO} & \mathrm{MnO} & \mathrm{MgO} & \mathrm{CaO} & \mathrm{NiO} & \mathrm{Cr}_{2} \mathrm{O}_{3} & \mathrm{Nb}_{2} \mathrm{O}_{3} & \mathrm{~V}_{2} \mathrm{O}_{3} & \mathrm{Total}\end{array}$

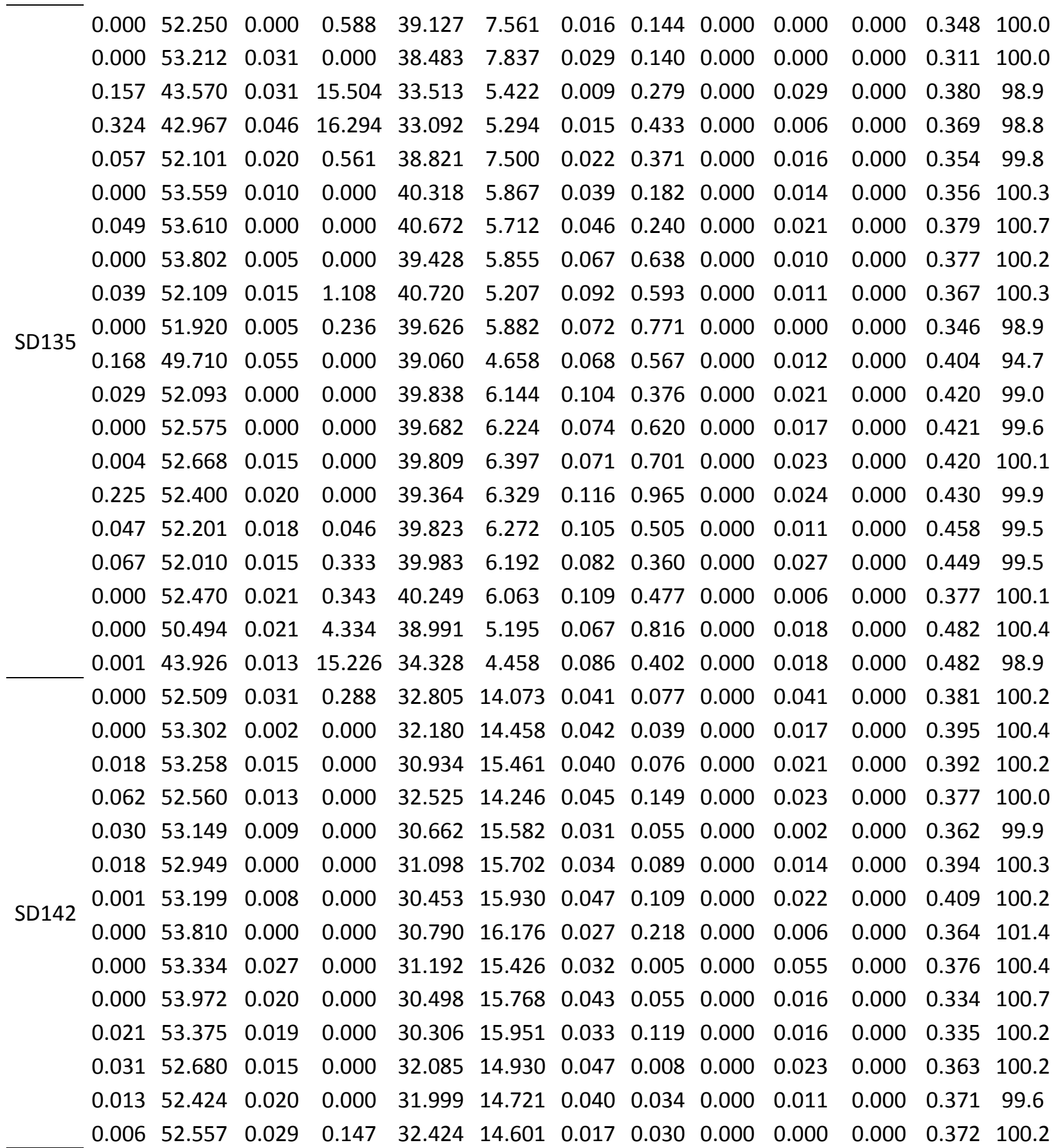


Annex 7 (Continued) EPMA ilmenites analysis in the Marmato porphyry group, recalculated to 3 oxygens and 2 cations.

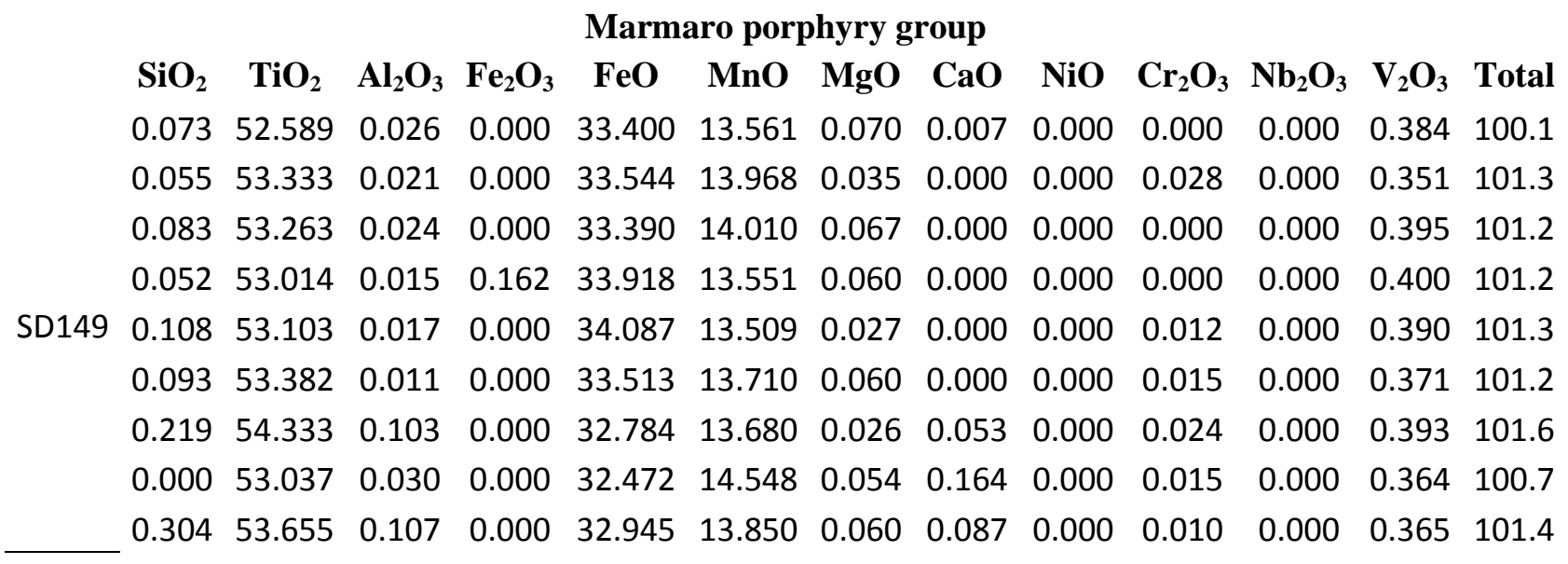

Annex 3. EPMA ilmenites analysis in the Aguas Claras porphyry group, recalculated to 3 oxygens and 2 cations.

Aguas Claras porphyry group

\begin{tabular}{|c|c|c|c|c|c|c|c|c|c|c|c|c|c|}
\hline & $\mathrm{SiO}_{2}$ & $\mathrm{TiO}_{2}$ & $\mathrm{Al}_{2} \mathbf{O}_{3}$ & $\mathrm{Fe}_{2} \mathrm{O}_{3}$ & $\mathrm{FeO}$ & MnO & MgO & $\mathrm{CaO}$ & $\mathrm{NiO}$ & $\mathrm{Cr}_{2} \mathrm{O}_{3}$ & $\mathbf{N b}_{2} \mathbf{O}_{3}$ & $\mathbf{V}_{2} \mathbf{O}_{3}$ & Total \\
\hline \multirow{7}{*}{ SD260 } & 085 & 8 & 0.016 & 9. & 3 & 8 & 8 & 7 & 0 & 9 & 0 & 0.475 & 100.6 \\
\hline & 0.049 & 455 & 0.071 & 9.661 & 36.759 & 857 & 0.029 & 000 & 000 & 0.014 & 0.000 & 0.449 & 3 \\
\hline & 0 & 47.310 & 0.006 & 10.221 & 36.755 & 5.635 & 0.045 & 000 & 000 & 4 & 00 & 441 & 100.4 \\
\hline & 0.103 & 47.492 & 0.028 & 9.973 & 36.830 & 5.870 & 037 & 0.000 & 0.000 & 0.015 & 0.000 & 45 & 8 \\
\hline & 0.000 & 29 & 0.025 & 10.409 & 3 & 8 & 026 & 000 & 0 & 01 & 00 & 61 & 100.1 \\
\hline & 0.033 & 47.941 & 0.018 & 9.108 & 37.212 & 5.856 & 0.010 & .000 & 0.000 & 0.011 & 0.000 & 0.426 & 6 \\
\hline & 0.0 & 47.199 & 0.000 & 9.910 & 77 & 06 & 49 & 00 & 00 & 11 & 00 & 39 & 100.1 \\
\hline \multirow{3}{*}{ SD256 } & 0.00 & 45.437 & 0.007 & 14.727 & 34.722 & 5.961 & 0.063 & 0.000 & 0.000 & 0.000 & 0.000 & 385 & \\
\hline & 0.022 & 44.611 & 0.004 & 16.222 & 33.960 & 5.944 & 0.097 & 0.000 & 0.000 & 0.000 & 0.000 & 0.378 & 101.2 \\
\hline & 0.000 & 45.093 & 0.029 & 15.584 & 34.310 & 5.997 & 0.099 & 0.000 & 0.000 & 0.000 & 0.000 & 0.369 & 101.5 \\
\hline \multirow{6}{*}{ SD261 } & 0.000 & 48.103 & 0.000 & 8.486 & 35.209 & 7.830 & 0.072 & 0.000 & 0.000 & 0.031 & 0.000 & 0.589 & 100.3 \\
\hline & 0.000 & 48.509 & 0.002 & 7.725 & 35.310 & 8.062 & 0.084 & 0.006 & 0.000 & 0.017 & 0.000 & 0.565 & 100.3 \\
\hline & 0.000 & 49.762 & 0.003 & 5.669 & 36.293 & 8.254 & 0.060 & 0.000 & 0.000 & 0.019 & 0.000 & 0.534 & 100.6 \\
\hline & 0.092 & 51.192 & 0.000 & 2.099 & 36.125 & 9.513 & 0.122 & 0.139 & 0.000 & 0.009 & 0.000 & 0.563 & 9.9 \\
\hline & 0.032 & 48.579 & 0.029 & 7.471 & 34.906 & 8.468 & 0.080 & 0.085 & 0.000 & 0.025 & 0.000 & 0.454 & .1 \\
\hline & 0.300 & 48.392 & 0.036 & 7.409 & 34.749 & 8.333 & 0.158 & 0.324 & 0.000 & 0.028 & 0.000 & 0.478 & 100.2 \\
\hline
\end{tabular}


Annex 4. U-Pb geochronological data obtained from Marmato group intrusions using MC-LA-ICP-MS .

\begin{tabular}{|c|c|c|c|c|c|c|c|c|c|c|}
\hline \multirow[b]{2}{*}{ Sample } & \multirow[b]{2}{*}{$f(206) \%$} & \multicolumn{5}{|c|}{ Ratios } & \multirow[b]{2}{*}{$2 s(\%)$} & \multirow[b]{2}{*}{ rho } & \multicolumn{2}{|c|}{ Age (Ma) } \\
\hline & & ${ }^{207} \mathrm{~Pb} /{ }^{206} \mathrm{~Pb}$ & $2 s(\%)$ & ${ }^{207} \mathrm{~Pb} /{ }^{235} \mathrm{U}$ & $2 s(\%)$ & ${ }^{206} \mathrm{~Pb} /{ }^{238} \mathrm{U}$ & & & ${ }^{206} \mathrm{~Pb} /{ }^{238} \mathrm{U}$ & $1 s(a b s)$ \\
\hline \multicolumn{11}{|c|}{$\begin{array}{c}\text { Marmato Porphyry Suite } \\
\text { Intrusion P1 }\end{array}$} \\
\hline Z18 & 0.28 & 0.04628 & 4.1 & 0.00637 & 4.7 & 0.00100 & 2.3 & 0.49 & 6.4 & 0.1 \\
\hline Z5 & 2.66 & 0.04788 & 10.4 & 0.00666 & 10.8 & 0.00101 & 3.1 & 0.29 & 6.5 & 0.2 \\
\hline Z22 & 0.96 & 0.04924 & 6.4 & 0.00685 & 6.6 & 0.00101 & 1.7 & 0.26 & 6.5 & 0.1 \\
\hline Z21 & 2.94 & 0.02720 & 72.6 & 0.00379 & 72.8 & 0.00101 & 5.5 & 0.08 & 6.5 & 0.4 \\
\hline Z9 & 1.10 & 0.04873 & 6.6 & 0.00680 & 6.9 & 0.00101 & 2.1 & 0.30 & 6.5 & 0.1 \\
\hline Z19 & 3.18 & 0.04785 & 7.0 & 0.00673 & 7.3 & 0.00102 & 2.1 & 0.28 & 6.6 & 0.1 \\
\hline Z10 & 1.34 & 0.04451 & 6.9 & 0.00627 & 7.3 & 0.00102 & 2.3 & 0.32 & 6.6 & 0.2 \\
\hline Z7 & 1.06 & 0.04900 & 4.5 & 0.00692 & 4.6 & 0.00102 & 1.2 & 0.25 & 6.6 & 0.1 \\
\hline Z25 & 0.90 & 0.04919 & 8.5 & 0.00696 & 8.6 & 0.00103 & 1.6 & 0.19 & 6.6 & 0.1 \\
\hline Z20 & 0.84 & 0.04385 & 6.6 & 0.00624 & 6.9 & 0.00103 & 2.0 & 0.29 & 6.7 & 0.1 \\
\hline Z23 & 1.16 & 0.04292 & 7.3 & 0.00612 & 7.6 & 0.00103 & 2.0 & 0.26 & 6.7 & 0.1 \\
\hline \multicolumn{11}{|c|}{ Intrusion P2 } \\
\hline $\mathrm{Z1}$ & 6.36 & 0.04138 & 22.3 & 0.00555 & 22.5 & 0.00097 & 2.4 & 0.11 & 6.3 & 0.1 \\
\hline Z14 & 2.95 & 0.04099 & 49.8 & 0.00556 & 50.0 & 0.00098 & 3.6 & 0.07 & 6.3 & 0.2 \\
\hline $\mathrm{Z} 12$ & 6.35 & 0.03862 & 11.0 & 0.00525 & 11.4 & 0.00099 & 2.7 & 0.24 & 6.4 & 0.2 \\
\hline Z11 & 3.16 & 0.04936 & 29.5 & 0.00674 & 29.7 & 0.00099 & 3.4 & 0.12 & 6.4 & 0.2 \\
\hline Z15 & 2.65 & 0.04226 & 19.8 & 0.00579 & 20.1 & 0.00099 & 3.4 & 0.17 & 6.4 & 0.2 \\
\hline Z5 & 2.47 & 0.04506 & 6.4 & 0.00620 & 6.7 & 0.00100 & 1.7 & 0.25 & 6.4 & 0.1 \\
\hline $\mathrm{Z} 28$ & 1.10 & 0.02773 & 96.6 & 0.00383 & 96.6 & 0.00100 & 3.7 & 0.04 & 6.5 & 0.2 \\
\hline \multicolumn{11}{|c|}{ Intrusion P3 } \\
\hline Z15 & 9.69 & 0.04602 & 6.7 & 0.00615 & 7.2 & 0.00097 & 2.8 & 0.38 & 6.2 & 0.2 \\
\hline $\mathrm{Z} 1$ & 5.10 & 0.04671 & 39.1 & 0.00626 & 39.3 & 0.00097 & 3.5 & 0.09 & 6.3 & 0.2 \\
\hline Z10 & 17.72 & 0.04476 & 20.9 & 0.00602 & 21.0 & 0.00098 & 2.2 & 0.10 & 6.3 & 0.1 \\
\hline Z29 & 1.62 & 0.04811 & 24.3 & 0.00652 & 24.4 & 0.00098 & 3.0 & 0.12 & 6.3 & 0.2 \\
\hline Z27 & 1.14 & 0.04633 & 5.6 & 0.00632 & 5.9 & 0.00099 & 2.0 & 0.34 & 6.4 & 0.1 \\
\hline Z28 & 0.87 & 0.04333 & 14.9 & 0.00589 & 15.0 & 0.00099 & 1.9 & 0.12 & 6.4 & 0.1 \\
\hline \multicolumn{11}{|c|}{ Intrusion P4 } \\
\hline Z17 & 1.26 & 0.04776 & 6.2 & 0.00647 & 6.8 & 0.00098 & 2.9 & 0.42 & 6.3 & 0.2 \\
\hline Z21 & 1.49 & 0.04511 & 14.4 & 0.00617 & 14.6 & 0.00099 & 2.6 & 0.18 & 6.4 & 0.2 \\
\hline $\mathrm{Z1}$ & 0.58 & 0.04747 & 15.3 & 0.00656 & 15.5 & 0.00100 & 2.4 & 0.16 & 6.5 & 0.2 \\
\hline Z12 & 2.61 & 0.04168 & 25.8 & 0.00577 & 25.9 & 0.00100 & 2.7 & 0.10 & 6.5 & 0.2 \\
\hline \multicolumn{11}{|c|}{ Intrusion P5 } \\
\hline Z22 & 2.73 & 0.03942 & 25.0 & 0.00467 & 25.3 & 0.00086 & 3.6 & 0.14 & 5.5 & 0.2 \\
\hline $\mathrm{Z7}$ & 0.93 & 0.04795 & 46.4 & 0.00574 & 46.7 & 0.00087 & 4.8 & 0.10 & 5.6 & 0.3 \\
\hline $\mathrm{Z} 6$ & 0.74 & 0.05152 & 9.5 & 0.00623 & 9.9 & 0.00088 & 2.7 & 0.27 & 5.6 & 0.2 \\
\hline $\mathrm{Z2}$ & 0.73 & 0.04869 & 9.8 & 0.00595 & 10.2 & 0.00089 & 2.8 & 0.28 & 5.7 & 0.2 \\
\hline Z5 & 0.36 & 0.04628 & 4.9 & 0.00575 & 5.1 & 0.00090 & 1.3 & 0.26 & 5.8 & 0.1 \\
\hline Z21 & 1.37 & 0.08187 & 9.7 & 0.01018 & 10.0 & 0.00090 & 2.4 & 0.24 & 5.8 & 0.1 \\
\hline
\end{tabular}


Annex 5. U-Pb geochronological data obtained from Aguas Claras group intrusions using MC-LA-ICP-MS.

\begin{tabular}{|c|c|c|c|c|c|c|c|c|c|c|}
\hline \multirow{2}{*}{ Sample } & \multirow{2}{*}{$f(206) \%$} & \multirow[b]{2}{*}{${ }^{207} \mathrm{~Pb} /{ }^{206} \mathrm{~Pb}$} & \multicolumn{3}{|c|}{ Ratios } & \multirow[b]{2}{*}{${ }^{206} \mathrm{~Pb}{ }^{238} \mathrm{U}$} & \multirow[b]{2}{*}{$2 s(\%)$} & \multirow[b]{2}{*}{ rho } & \multicolumn{2}{|c|}{ Age (Ma) } \\
\hline & & & $2 s(\%)$ & ${ }^{207} \mathrm{~Pb}{ }^{235} \mathrm{U}$ & $2 s(\%)$ & & & & ${ }^{206} \mathrm{~Pb} /{ }^{238} \mathrm{U}$ & $1 s$ (abs) \\
\hline \multicolumn{11}{|c|}{ Intrusion AP1 } \\
\hline Z1 & 1.10 & 0.01760 & 71.1 & 0.00214 & 71.2 & 0.00088 & 2.3 & 0.03 & 5.7 & 0.1 \\
\hline Z23 & 0.95 & 0.07322 & 27.3 & 0.00898 & 27.8 & 0.00089 & 5.1 & 0.18 & 5.7 & 0.1 \\
\hline Z9 & 0.96 & 0.07195 & 8.8 & 0.00888 & 9.6 & 0.00090 & 3.7 & 0.38 & 5.8 & 0.1 \\
\hline Z6 & 2.56 & 0.02163 & 93.3 & 0.00268 & 93.4 & 0.00090 & 4.8 & 0.05 & 5.8 & 0.3 \\
\hline $\mathrm{Z7}$ & 2.44 & 0.04187 & 81.3 & 0.00525 & 81.8 & 0.00091 & 9.0 & 0.11 & 5.9 & 0.5 \\
\hline \multicolumn{11}{|c|}{ Intrusion AP2 } \\
\hline Z16 & 3.10 & 0.03564 & 74.2 & 0.00464 & 74.5 & 0.00094 & 6.4 & 0.09 & 6.1 & 0.4 \\
\hline Z6 & 2.36 & 0.04839 & 29.6 & 0.00658 & 29.9 & 0.00099 & 4.6 & 0.15 & 6.4 & 0.3 \\
\hline Z12 & 0.45 & 0.04362 & 9.8 & 0.00595 & 10.3 & 0.00099 & 3.3 & 0.31 & 6.4 & 0.2 \\
\hline Z21 & 2.49 & 0.04940 & 12.3 & 0.00677 & 12.8 & 0.00099 & 3.5 & 0.27 & 6.4 & 0.2 \\
\hline $\mathrm{Z1}$ & 1.46 & 0.05022 & 7.9 & 0.00689 & 8.2 & 0.00099 & 2.4 & 0.29 & 6.4 & 0.2 \\
\hline $\mathrm{Z7}$ & 2.93 & 0.04955 & 6.5 & 0.00681 & 6.9 & 0.00100 & 2.3 & 0.33 & 6.4 & 0.1 \\
\hline $\mathrm{Z} 2$ & 0.92 & 0.04682 & 4.6 & 0.00658 & 5.1 & 0.00102 & 2.1 & 0.41 & 6.6 & 0.1 \\
\hline $\mathrm{Z} 4$ & 8.77 & 0.05295 & 16.6 & 0.00748 & 16.8 & 0.00102 & 2.4 & 0.14 & 6.6 & 0.2 \\
\hline \multicolumn{11}{|c|}{ Intrusion AP3 } \\
\hline Z6 & 0.92 & 0.04273 & 7.2 & 0.00581 & 7.6 & 0.00099 & 2.5 & 0.33 & 6.3 & 0.2 \\
\hline Z11 & 19.36 & 0.02402 & 110.5 & 0.00331 & 110.6 & 0.00100 & 5.5 & 0.05 & 6.4 & 0.4 \\
\hline Z19 & 3.91 & 0.05178 & 11.2 & 0.00726 & 11.8 & 0.00102 & 3.7 & 0.31 & 6.5 & 0.2 \\
\hline Z24 & 6.14 & 0.05047 & 28.9 & 0.00713 & 29.3 & 0.00102 & 4.4 & 0.15 & 6.6 & 0.3 \\
\hline $\mathrm{Z} 2$ & 3.07 & 0.04817 & 8.1 & 0.00680 & 8.4 & 0.00102 & 2.2 & 0.27 & 6.6 & 0.1 \\
\hline Z22 & 2.79 & 0.05298 & 11.0 & 0.00752 & 11.2 & 0.00103 & 2.2 & 0.19 & 6.6 & 0.1 \\
\hline Z12 & 5.30 & 0.05308 & 105.9 & 0.00763 & 106.4 & 0.00104 & 10.2 & 0.10 & 6.7 & 0.7 \\
\hline Z8 & 3.73 & 0.04495 & 50.9 & 0.00652 & 51.1 & 0.00105 & 5.2 & 0.10 & 6.8 & 0.4 \\
\hline \multicolumn{11}{|c|}{ Intrusion AP4 } \\
\hline Z12 & 1.45 & 0.04848 & 11.8 & 0.00656 & 12.1 & 0.00098 & 2.5 & 0.21 & 6.3 & 0.2 \\
\hline Z31 & 7.56 & 0.02336 & 71.2 & 0.00319 & 71.3 & 0.00099 & 4.5 & 0.06 & 6.4 & 0.3 \\
\hline Z29 & 1.06 & 0.02789 & 42.4 & 0.00383 & 42.6 & 0.00100 & 3.9 & 0.09 & 6.4 & 0.3 \\
\hline Z6 & 5.68 & 0.02887 & 129.9 & 0.00398 & 130.4 & 0.00100 & 11.0 & 0.08 & 6.4 & 0.7 \\
\hline Z28 & 4.02 & 0.02619 & 29.8 & 0.00365 & 29.9 & 0.00101 & 2.2 & 0.07 & 6.5 & 0.1 \\
\hline Z16 & 1.37 & 0.03368 & 33.5 & 0.00470 & 33.8 & 0.00101 & 4.4 & 0.13 & 6.5 & 0.3 \\
\hline Z14 & 7.31 & 0.04415 & 21.3 & 0.00618 & 21.6 & 0.00101 & 3.9 & 0.18 & 6.5 & 0.3 \\
\hline $\mathrm{Z} 10$ & 1.76 & 0.04974 & 11.1 & 0.00699 & 11.4 & 0.00102 & 2.8 & 0.24 & 6.6 & 0.2 \\
\hline $\mathrm{Z3}$ & 1.88 & 0.04805 & 17.8 & 0.00686 & 18.3 & 0.00104 & 4.0 & 0.22 & 6.7 & 0.3 \\
\hline \multicolumn{11}{|c|}{ Intrusion AP5 } \\
\hline Z18 & 1.51 & 0.03176 & 27.9 & 0.00418 & 28.2 & 0.00096 & 3.8 & 0.13 & 6.2 & 0.2 \\
\hline Z24 & 1.27 & 0.03354 & 42.0 & 0.00444 & 42.3 & 0.00096 & 4.6 & 0.11 & 6.2 & 0.3 \\
\hline Z9 & 1.54 & 0.04606 & 12.2 & 0.00610 & 12.3 & 0.00096 & 1.8 & 0.15 & 6.2 & 0.1 \\
\hline $\mathrm{Z4}$ & 0.79 & 0.04373 & 7.1 & 0.00583 & 7.2 & 0.00097 & 1.3 & 0.18 & 6.2 & 0.1 \\
\hline Z28 & 1.73 & 0.04628 & 21.2 & 0.00627 & 21.4 & 0.00098 & 3.0 & 0.14 & 6.3 & 0.2 \\
\hline Z27 & 0.67 & 0.04342 & 9.1 & 0.00589 & 9.5 & 0.00098 & 2.9 & 0.30 & 6.3 & 0.2 \\
\hline $\mathrm{Z12}$ & 2.10 & 0.04623 & 14.4 & 0.00627 & 14.5 & 0.00098 & 2.1 & 0.14 & 6.3 & 0.1 \\
\hline $\mathrm{Z} 8$ & 3.48 & 0.04785 & 15.3 & 0.00650 & 15.6 & 0.00099 & 3.0 & 0.19 & 6.3 & 0.2 \\
\hline $\mathrm{Z7}$ & 1.10 & 0.04564 & 11.5 & 0.00621 & 11.5 & 0.00099 & 1.4 & 0.12 & 6.4 & 0.1 \\
\hline $\mathrm{Z5}$ & 0.78 & 0.04759 & 5.9 & 0.00649 & 6.1 & 0.00099 & 1.4 & 0.23 & 6.4 & 0.1 \\
\hline Z11 & 3.14 & 0.04119 & 28.1 & 0.00562 & 28.2 & 0.00099 & 2.7 & 0.10 & 6.4 & 0.2 \\
\hline $\mathrm{Z} 6$ & 1.06 & 0.05098 & 9.4 & 0.00697 & 9.6 & 0.00099 & 1.6 & 0.17 & 6.4 & 0.1 \\
\hline
\end{tabular}


Annex 6. Ar-Ar geochronological plateau age data obtained from hydrothermal adularia in the Marmato gold deposit (Upper zone).

\begin{tabular}{|c|c|c|c|c|c|c|c|c|c|c|c|c|}
\hline \multicolumn{2}{|c|}{$\begin{array}{c}\text { Incremental } \\
\text { Heating }\end{array}$} & \multirow{2}{*}{$\begin{array}{c}\begin{array}{c}\text { 36Ar(a) } \\
\text { [fA] }\end{array} \\
14.546781\end{array}$} & \multirow{2}{*}{$\begin{array}{c}\begin{array}{c}\text { 37Ar(ca) } \\
\text { [fA] }\end{array} \\
0.191518\end{array}$} & \multirow{2}{*}{$\begin{array}{c}\begin{array}{c}\text { 38Ar(cl) } \\
\text { [fA] }\end{array} \\
0.8097759\end{array}$} & \multirow{2}{*}{$\begin{array}{c}\begin{array}{c}\text { 39Ar(k) } \\
\text { [fA] }\end{array} \\
796.675\end{array}$} & \multirow{2}{*}{$\begin{array}{c}\begin{array}{c}\text { 40Ar(r) } \\
\text { [fA] }\end{array} \\
916.062\end{array}$} & \multirow{2}{*}{$\begin{array}{r}\text { Age (Ma) } \\
6.11\end{array}$} & \multirow{2}{*}{$\begin{array}{c} \pm 2 \mathrm{~s} \\
\pm 0.16\end{array}$} & \multirow{2}{*}{$\begin{array}{c}\begin{array}{c}\text { 40Ar(r) } \\
(\%)\end{array} \\
17.56\end{array}$} & \multirow{2}{*}{$\begin{array}{r}\begin{array}{c}\text { 39Ar(k) } \\
(\%)\end{array} \\
6.82\end{array}$} & \multirow{2}{*}{$\begin{array}{r}\text { K/Ca } \\
1789\end{array}$} & \multirow{2}{*}{$\begin{array}{r} \pm 2 s \\
\pm 1904\end{array}$} \\
\hline 15D16099 & $18.00 \%$ & & & & & & & & & & & \\
\hline 15D16101 & $18.00 \%$ & 2.086299 & 0.06028 & 0.6616616 & 640.695 & 720.397 & 5.97 & \pm 0.03 & 53.86 & 5.48 & 4570 & \pm 16413 \\
\hline 15D16103 & $18.00 \%$ & 1.532278 & 4.454669 & 0.741016 & 1036.141 & 1159.72 & 5.95 & \pm 0.02 & 71.87 & 8.87 & 100 & \pm 5 \\
\hline 15D16105 & $18.00 \%$ & 1.103519 & 0.078128 & 0.1515875 & 309.473 & 348.354 & 5.98 & \pm 0.04 & 51.63 & 2.65 & 1703 & \pm 4719 \\
\hline 15D16107 & $18.00 \%$ & 0.50927 & 1.236133 & 0.3413965 & 493. & & 94 & & 51 & 22 & 172 & \pm 31 \\
\hline 15D16109 & $18.00 \%$ & 1.099613 & 0.07169 & 0.3844909 & 628.47 & 703.499 & 5.95 & \pm 0.02 & 68.36 & 5.38 & 3770 & \pm 11231 \\
\hline 15D16111 & $18.00 \%$ & 1.053724 & 0.19447 & 0.4417636 & 465.213 & 523.661 & 5.98 & & 62.68 & 3.98 & 1029 & \\
\hline 15D16113 & $18.00 \%$ & 2.279643 & 0.023436 & 0.4694433 & 617.728 & 698.44 & 6.01 & \pm 0.04 & 50.88 & 5.29 & 11334 & \pm 104999 \\
\hline 15D16115 & $18.00 \%$ & 0.844096 & 0.049939 & 0.3056366 & 386.35 & 429.65 & 5.91 & \pm 0.03 & 63.23 & 3.31 & 3327 & \pm 14089 \\
\hline & & & & & & & & & & & 2219 & \\
\hline 15D16119 & $18.00 \%$ & 0.852457 & 2.782723 & 0.3800749 & 481.061 & 545.911 & 6.03 & \pm 0.02 & 68.38 & 4.12 & 74 & \pm 6 \\
\hline 15D16121 & $18.00 \%$ & 0.433752 & 5.111019 & 0.3806923 & 376.342 & 422.638 & 5.96 & \pm 0.02 & 76.68 & 3.22 & 32 & \pm 1 \\
\hline 15D16123 & $18.00 \%$ & 1.011439 & 3.792778 & 0.421998 & 554.848 & 620.698 & 5.94 & \pm 0.02 & 67.46 & 4.75 & 63 & \pm 4 \\
\hline 15D16125 & $18.00 \%$ & 1.623206 & 1.238537 & 0.3142869 & 364.552 & 413.518 & 6.02 & \pm 0.05 & 46.28 & 3.12 & 127 & \pm 22 \\
\hline 15D16127 & $18.00 \%$ & 2.586862 & 0.005976 & 0.2526802 & 370.973 & 409.907 & 5.87 & \pm 0.07 & 34.89 & 3.17 & 26692 & \pm 956796 \\
\hline 15D16129 & $18.00 \%$ & 1.41527 & 2.462042 & 0.3358358 & 328.523 & 364.102 & 5.89 & \pm 0.05 & 46.52 & 2.81 & 57 & \pm 5 \\
\hline 15D16131 & $18.00 \%$ & 0.080331 & 0.348361 & 0.2791579 & 336.046 & 377.194 & 5.96 & \pm 0.01 & 94 & 2.88 & 415 & \pm 259 \\
\hline 15D16133 & $18.00 \%$ & 0.653422 & 0.402518 & 0.1681096 & 310.615 & 347.121 & 5.94 & \pm 0.03 & 64.22 & 2.66 & 332 & \pm 184 \\
\hline 15D16135 & $18.00 \%$ & 9.651663 & 2.442199 & 0.7852069 & 964.416 & 1073.415 & 5.91 & \pm 0.09 & 27.34 & 8.25 & 170 & \pm 15 \\
\hline 15D16137 & $18.00 \%$ & 3.046013 & 0.047622 & 0.8382068 & 1357.153 & 1531.778 & 5.99 & \pm 0.02 & 62.95 & 11.61 & 12254 & \pm 54236 \\
\hline
\end{tabular}


Annex 7. Ar-Ar geochronological plateau age data obtained from hydrothermal adularia in the Marmato gold deposit (Lower zone).

\begin{tabular}{|c|c|c|c|c|c|c|c|c|c|c|c|c|}
\hline \multicolumn{2}{|c|}{$\begin{array}{l}\text { Incremental } \\
\text { Heating }\end{array}$} & \multirow{2}{*}{$\begin{array}{c}\begin{array}{c}\text { 36Ar(a) } \\
\text { [fA] }\end{array} \\
2.172108\end{array}$} & \multirow{2}{*}{$\begin{array}{c}\begin{array}{c}\text { 37Ar(ca) } \\
\text { [fA] }\end{array} \\
0.059284\end{array}$} & \multirow{2}{*}{$\begin{array}{c}\begin{array}{c}\text { 38Ar(cl) } \\
\text { [fA] }\end{array} \\
0.663033\end{array}$} & \multirow{2}{*}{$\begin{array}{c}\begin{array}{c}\text { 39Ar(k) } \\
\text { [fA] }\end{array} \\
823.7866\end{array}$} & \multirow{2}{*}{$\begin{array}{c}\begin{array}{c}\text { 40Ar(r) } \\
\text { [fA] }\end{array} \\
942.978\end{array}$} & \multirow{2}{*}{$\begin{array}{r}\text { Age (Ma) } \\
6.06\end{array}$} & \multirow{2}{*}{$\begin{array}{c} \pm 2 \mathrm{~s} \\
\pm 0.03\end{array}$} & \multirow{2}{*}{$\begin{array}{c}\begin{array}{c}\text { 40Ar(r) } \\
\text { (\%) }\end{array} \\
59.47\end{array}$} & \multirow{2}{*}{$\begin{array}{c}\begin{array}{c}\text { 39Ar(k) } \\
\text { (\%) }\end{array} \\
8.57\end{array}$} & \multirow{2}{*}{$\begin{array}{r}\text { K/Ca } \\
5975\end{array}$} & \multirow{2}{*}{$\begin{array}{c} \pm 2 s \\
\pm 23560\end{array}$} \\
\hline 15D16139 & $18.00 \%$ & & & & & & & & & & & \\
\hline 15D16141 & $18.00 \%$ & 0.250542 & 0.177623 & 0.329885 & 346.9211 & 396.865 & 6.06 & \pm 0.02 & 84.22 & 3.61 & 840 & \pm 1074 \\
\hline 15D16143 & $18.00 \%$ & 1.103858 & 0.077618 & 0.893337 & 512.5171 & 585.864 & 6.05 & \pm 0.03 & 64.2 & 5.33 & 2839 & \pm 7985 \\
\hline 15D16145 & $18.00 \%$ & 0.150737 & 5.047784 & 0.583067 & 466.0621 & 533.723 & 6.07 & \pm 0.01 & 92.22 & 4.85 & 40 & \pm 2 \\
\hline 15D16147 & $18.00 \%$ & 1.951342 & 0.306006 & 1.220049 & 324.9477 & 379.22 & 6.18 & \pm 0.06 & 39.66 & 3.38 & 457 & \pm 262 \\
\hline 15D16149 & $18.00 \%$ & 0.107175 & 1.408425 & 0.786048 & 928.9299 & 1060.345 & 6.05 & \pm 0.01 & 97.02 & 9.66 & 284 & \pm 37 \\
\hline 15D16151 & $18.00 \%$ & 0.925741 & 0.107631 & 0.942787 & 313.3376 & 364.742 & 6.16 & \pm 0.04 & 57.11 & 3.26 & 1252 & \pm 1921 \\
\hline 15D16153 & $18.00 \%$ & 0.695833 & 1.032245 & 0.79677 & 640.2651 & 729.452 & 6.03 & \pm 0.02 & 77.96 & 6.66 & 267 & \pm 50 \\
\hline 15D16155 & $18.00 \%$ & 0.241549 & 0.206351 & 0.562929 & 655.7058 & 745.187 & 6.02 & \pm 0.01 & 91.18 & 6.82 & 1366 & \pm 1097 \\
\hline 15D16157 & $18.00 \%$ & 0.08037 & 0.145338 & 0.09053 & 10.9285 & & 6.84 & & & 0.11 & 32 & \pm 41 \\
\hline 15D16159 & $18.00 \%$ & 0.126537 & 0.028138 & 0.323715 & 406.589 & 465.335 & 6.06 & \pm 0.01 & 92.49 & 4.23 & 6213 & \pm 37535 \\
\hline 15D16161 & $18.00 \%$ & 0.090901 & 0.010677 & 0.310754 & 377.2907 & 429.85 & 6.03 & \pm 0.01 & 94.04 & 3.92 & 15195 & \pm 260421 \\
\hline 15D16163 & $18.00 \%$ & 0.241757 & 0.128149 & 0.515337 & 343.5657 & 392.143 & 6.05 & \pm 0.02 & 84.53 & 3.57 & 1153 & \pm 1499 \\
\hline 15D16165 & $18.00 \%$ & 0.153152 & 0.161203 & 0.255977 & 235.1076 & 266.358 & 6 & \pm 0.02 & 85.41 & 2.45 & 627 & \pm 724 \\
\hline 15D16167 & $18.00 \%$ & 0.07113 & 0.082452 & 0.297567 & 265.2262 & 303.699 & 6.06 & \pm 0.01 & 93.45 & 2.76 & 1383 & \pm 3053 \\
\hline 15D16169 & $18.00 \%$ & 0.349469 & 0.126357 & 0.30673 & 248.3713 & 285.468 & 6.09 & \pm 0.02 & 73.39 & 2.58 & 845 & \pm 1277 \\
\hline 15D16171 & $18.00 \%$ & 0.543489 & 0.039604 & 0.316455 & 256.1501 & 292.064 & 6.04 & \pm 0.03 & 64.48 & 2.66 & 2781 & \pm 12574 \\
\hline $15 \mathrm{D} 16173$ & $18.00 \%$ & 0.258982 & 0.060159 & 0.361851 & 295.4471 & 334.475 & 6 & \pm 0.02 & 81.32 & 3.07 & 2112 & \pm 6654 \\
\hline $15 \mathrm{D} 16175$ & $18.00 \%$ & 5.10004 & 0.054507 & 0.93763 & 226.2103 & 267.426 & 6.26 & \pm 0.21 & 15.07 & 2.35 & 1785 & \pm 5920 \\
\hline 15D16177 & $18.00 \%$ & 7.791682 & 10.608893 & 1.761982 & 1937.3435 & 2213.036 & 6.05 & \pm 0.04 & 48.99 & 20.15 & 79 & \pm 1 \\
\hline
\end{tabular}


Annex 8. Ar-Ar geochronological isochron age data obtained from hydrothermal adularia in the Marmato gold deposit (Upper zone).

\begin{tabular}{|c|c|c|c|c|c|c|}
\hline \multicolumn{2}{|c|}{$\begin{array}{l}\text { Inverse } \\
\text { Isochron }\end{array}$} & \multirow{2}{*}{$\begin{array}{r}\mathbf{3 9}(\mathbf{k}) / \mathbf{4 0}(\mathbf{a}+\mathbf{r}) \\
0.152776682\end{array}$} & \multirow{2}{*}{$\frac{ \pm 2 \mathrm{~s}}{.000199588}$} & \multirow{2}{*}{$\frac{\mathbf{3 6}(\mathbf{a}) / \mathbf{4 0}(\mathbf{a}+\mathbf{r})}{0.002789606}$} & \multirow{2}{*}{$\frac{ \pm 2 \mathrm{~s}}{1.57793 \mathrm{E}-05}$} & \multirow{2}{*}{$\begin{array}{c}\text { r.i. } \\
0.001684322\end{array}$} \\
\hline 15D16099 & $18 \%$ & & & & & \\
\hline 15D16101 & $18 \%$ & 0.479239873 & 0.000630795 & 0.001560552 & 1.03654E-05 & 0.003196849 \\
\hline 15D16103 & $18 \%$ & 0.642564823 & 0.000840553 & 0.000950245 & 6.24227E-06 & 0.002491166 \\
\hline 15D16105 & $18 \%$ & 0.458855913 & 0.000617038 & 0.001636191 & 1.22761E-05 & 0.004680854 \\
\hline 15D16107 & $18 \%$ & 0.70307 & 0.000934184 & 0.000725274 & 6.30221E-06 & 0.00 \\
\hline 15D16109 & $18 \%$ & 0.611093842 & 0.000805077 & 0.00106921 & 7.91754E-06 & 0.003053129 \\
\hline 15D16111 & $18 \%$ & 0.557117124 & 0.000740275 & 0.001261889 & $9.58816 \mathrm{E}-06$ & 0.003796029 \\
\hline 15D16113 & $18 \%$ & 0.450214414 & 0.00059197 & 0.001661457 & 1.05968E-05 & 0.00332786 \\
\hline 15D16115 & $18 \%$ & 0.568930587 & 0.000760377 & 0.001242999 & $9.55085 \mathrm{E}-06$ & 0.004527684 \\
\hline 15D16117 & $18 \%$ & & 0.0006 & & 9.697 & 0.002 \\
\hline 15D16119 & $18 \%$ & 0.602975123 & 0.000801509 & 0.001068493 & 7.89677E-06 & 0.004301243 \\
\hline 15D16121 & $18 \%$ & 0.683250377 & 0.000916788 & 0.000787477 & 7.30317E-06 & 0.004605745 \\
\hline 15D16123 & $18 \%$ & 0.603373006 & 0.00079756 & 0.001099895 & 7.83001E-06 & 0.003477996 \\
\hline 15D16125 & $18 \%$ & 0.408152808 & 0.000546469 & 0.001817343 & 1.22789E-05 & 0.004064328 \\
\hline 15D16127 & $18 \%$ & 0.315903045 & 0.000421042 & 0.002202851 & 1.42149E-05 & 0.003930925 \\
\hline 15D16129 & $18 \%$ & 0.419937761 & 0.000564046 & 0.001809082 & 1.25965E-05 & 0.004671602 \\
\hline 15D16131 & $18 \%$ & 0.838161726 & 0.001145214 & 0.000200361 & 4.09047E-06 & 0.003369437 \\
\hline 15D16133 & $18 \%$ & 0.574992165 & 0.000780918 & 0.001209576 & 1.00732E-05 & 0.006089624 \\
\hline 15D16135 & $18 \%$ & 0.245680839 & 0.000320541 & 0.002458721 & 1.41786E-05 & 0.001862334 \\
\hline 15D16137 & $18 \%$ & 0.558068796 & 0.000726205 & 0.001252537 & 7.73962E-06 & 0.001917648 \\
\hline
\end{tabular}


Annex 9. Ar-Ar geochronological isochron age data obtained from hydrothermal adularia in the Marmato gold deposit (Lower zone).

\begin{tabular}{ccrcrrr}
\hline $\begin{array}{c}\text { Inverse } \\
\text { Isochron }\end{array}$ & $\mathbf{3 9 ( k ) / 4 0 ( a + r )}$ & $\pm \mathbf{2 s}$ & $\mathbf{3 6 ( a ) / 4 0 ( a + r )}$ & $\pm 2 s$ & \multicolumn{1}{c}{ r.i. } \\
\hline 15D16139 & $18 \%$ & 0.519793125 & 0.00068113 & 0.001370558 & $8.83307 \mathrm{E}-06$ & 0.002688434 \\
15D16141 & $18 \%$ & 0.736719898 & 0.00100224 & 0.000532049 & $6.4095 \mathrm{E}-06$ & 0.004695489 \\
15D16143 & $18 \%$ & 0.561937404 & 0.00074369 & 0.0012103 & $8.81162 \mathrm{E}-06$ & 0.003404536 \\
15D16145 & $18 \%$ & 0.805965613 & 0.00107584 & 0.000260671 & $3.892 \mathrm{E}-06$ & 0.002692179 \\
15D16147 & $18 \%$ & 0.33995978 & 0.00045587 & 0.002041491 & $1.30062 \mathrm{E}-05$ & 0.00435687 \\
15D16149 & $18 \%$ & 0.850656537 & 0.00111311 & $9.81438 \mathrm{E}-05$ & $1.71106 \mathrm{E}-06$ & 0.001113461 \\
15D16151 & $18 \%$ & 0.490895368 & 0.00066449 & 0.001450327 & $1.13017 \mathrm{E}-05$ & 0.004710108 \\
15D16153 & $18 \%$ & 0.684723438 & 0.00090329 & 0.00074415 & $6.03116 \mathrm{E}-06$ & 0.003839505 \\
15D16155 & $18 \%$ & 0.803004973 & 0.00105971 & 0.000295811 & $3.30329 \mathrm{E}-06$ & 0.002480621 \\
15D16157 & $18 \%$ & 0.288530557 & 0.00209845 & 0.002121892 & $4.80393 \mathrm{E}-05$ & 0.027109215 \\
15D16159 & $18 \%$ & 0.808767151 & 0.00108452 & 0.000251702 & $4.08982 \mathrm{E}-06$ & 0.002966203 \\
15D16161 & $18 \%$ & 0.82610405 & 0.00111415 & 0.000199034 & $4.01502 \mathrm{E}-06$ & 0.002792275 \\
15D16163 & $18 \%$ & 0.741110633 & 0.00100856 & 0.000521497 & $6.02435 \mathrm{E}-06$ & 0.005129091 \\
15D16165 & $18 \%$ & 0.754481814 & 0.00105385 & 0.000491478 & $7.12901 \mathrm{E}-06$ & 0.005562723 \\
15D16167 & $18 \%$ & 0.816790646 & 0.00112827 & 0.000219051 & $4.99463 \mathrm{E}-06$ & 0.003864925 \\
15D16169 & $18 \%$ & 0.638920449 & 0.00088341 & 0.000898989 & $9.07034 \mathrm{E}-06$ & 0.00676188 \\
15D16171 & $18 \%$ & 0.565871465 & 0.00077777 & 0.001200644 & $1.00698 \mathrm{E}-05$ & 0.007594869 \\
15D16173 & $18 \%$ & 0.718842644 & 0.00098669 & 0.00063012 & $7.04177 \mathrm{E}-06$ & 0.005733803 \\
15D16175 & $18 \%$ & 0.127479264 & 0.00017328 & 0.002874092 & $1.72621 \mathrm{E}-05$ & 0.002561056 \\
15D16177 & $18 \%$ & 0.429045014 & 0.00055745 & 0.00172555 & $1.01054 \mathrm{E}-05$ & 0.001854296 \\
\hline
\end{tabular}


Annex 10. Sr/Nd isotopic compositions of the MACS

\begin{tabular}{cccccccc}
\hline Sample & Sm(ppm) & $N d(p p m)$ & ${ }^{147} S m /{ }^{144} N d$ & ${ }^{143} N d{ }^{144} N d \pm 2 S E$ & $e_{N d(0)}$ & $T_{D M}(\mathrm{Ga})$ & ${ }^{87} S r /{ }^{86} S r \pm 2 S E$ \\
\hline P1 & 2.924 & 12.523 & 0.1412 & $0.512808 \pm 7$ & 3.31 & 0.52 & \\
P2 & 2.637 & 12.19 & 0.1307 & $0.512790 \pm 90$ & 2.96 & 0.49 & $0.70479 \pm 2$ \\
P3 & 4.883 & 24.576 & 0.1201 & $0.512772 \pm 13$ & 2.62 & 0.46 & $0.7048 \pm 1$ \\
P4 & 4.383 & 24.14 & 0.1098 & $0.512688 \pm 13$ & 0.97 & 0.54 & $0.70756 \pm 5$ \\
P5 & 1.904 & 9.303 & 0.1237 & $0.512898 \pm 29$ & 5.08 & 0.28 & $0.70435 \pm 1$ \\
AP1 & 3.581 & 18.228 & 0.1188 & $0.512829 \pm 5$ & 3.72 & 0.37 & \\
AP2 & 5.184 & 26.821 & 0.1168 & $0.512806 \pm 23$ & 3.28 & 0.4 & $0.70492 \pm 2$ \\
AP3 & 2.719 & 13.872 & 0.1185 & $0.512826 \pm 7$ & 3.66 & 0.37 & $0.70453 \pm 1$ \\
AP4 & 3.175 & 15.422 & 0.1244 & $0.512935 \pm 19$ & 5.79 & 0.22 & $0.70513 \pm 1$ \\
AP5 & 4.621 & 23.45 & 0.1191 & $0.512693 \pm 20$ & 1.07 & 0.58 & $0.7045 \pm 3$
\end{tabular}

